Florida International University FIU Digital Commons

4-19-2017

\title{
HIV Risk Behaviors, Previous HIV Testing and Positivity among Hispanic Women Tested for HIV in Florida, 2012
}

Janelle Taveras

Department of Epidemiology, Florida International University, jtave003@fiu.edu

DOI: $10.25148 /$ etd.FIDC001938

Follow this and additional works at: https:// digitalcommons.fiu.edu/etd

Part of the Community Health and Preventive Medicine Commons, Epidemiology Commons, and the Women's Health Commons

\section{Recommended Citation}

Taveras, Janelle, "HIV Risk Behaviors, Previous HIV Testing and Positivity among Hispanic Women Tested for HIV in Florida, 2012" (2017). FIU Electronic Theses and Dissertations. 3456.

https://digitalcommons.fiu.edu/etd/3456

This work is brought to you for free and open access by the University Graduate School at FIU Digital Commons. It has been accepted for inclusion in FIU Electronic Theses and Dissertations by an authorized administrator of FIU Digital Commons. For more information, please contact dcc@fiu.edu. 


\section{FLORIDA INTERNATIONAL UNIVERSITY}

Miami, Florida

HIV RISK BEHAVIORS, PREVIOUS HIV TESTING AND POSITIVITY AMONG HISPANIC WOMEN TESTED FOR HIV IN FLORIDA, 2012

A dissertation submitted in partial fulfillment of the

requirements for the degree of

DOCTOR OF PHILOSOPHY

in

PUBLIC HEALTH

by

Janelle Taveras

2017 
To: Dean Tomás R. Guilarte

Robert Stempel College of Public Health and Social Work

This dissertation, written by Janelle Taveras, and entitled, HIV Risk Behaviors, previous HIV Testing and Positivity among Hispanic Women Tested for HIV in Florida, 2012, having been approved in respect to style and intellectual content, is referred to you for judgment.

We have read this dissertation and recommend that it be approved.

Jessy G. Dévieux

Erica L. Gollub

Boubakari Ibrahimou

Purnima Madhivanan

Mary Jo Trepka, Major Professor

Date of Defense: April 19, 2017

The dissertation of Janelle Taveras is approved.

Dean Tomás R. Guilarte Robert Stempel College of Public Health and Social Work

Andres G. Gil

Vice President for Research and Economic Development and Dean of the University Graduate School

Florida International University, 2017 
(C) Copyright 2017 by Janelle Taveras

All rights reserved 


\section{DEDICATION}

This dissertation is dedicated to my parents Samuel and Yvonne Taveras, my husband Abraham Gomez, and my son Jason Emiliano Gomez Taveras. 


\section{ACKNOWLEDGMENTS}

I would like to thank my dissertation committee, the Departments of Epidemiology, Biostatistics and Health Promotion and the Florida Department of Health for their continuous support throughout my doctoral studies. I am thankful for the support, expertise and patience provided by my dissertation committee, especially my major professor, Dr. Mary Jo Trepka. I can say that her professionalism, experience and commitment to support my work facilitated a rich and meaningful experience. I would also like to thank my family. My parents for their encouragement and prayers and my husband and son for the motivation to endure to the end. Finally, and most importantly, I thank the Lord Jesus Christ, with all my heart for reminding me that he who has begun a work in me will bring it to completion. 


\title{
ABSTRACT OF THE DISSERTATION
}

\section{HIV RISK BEHAVIORS, PREVIOUS HIV TESTING AND POSITIVITY AMONG HISPANIC WOMEN TESTED FOR HIV IN FLORIDA, 2012}

by

\author{
Janelle Taveras
}

Florida International University, 2017

\author{
Miami, Florida
}

\section{Professor Mary Jo Trepka, Major Professor}

The prevalence of female adults and adolescents living with diagnosed HIV infection continues to rise. Latina women in the United States (US) are not only disproportionately affected by human immunodeficiency virus (HIV) infection, but also underutilize HIV prevention services, such as HIV testing. Data are limited on the differences in HIV risk among Latinas by country of birth, and opportunities still exist to prevent transmission of HIV and reduce HIV-related disparities. This dissertation describes the risk behaviors, testing behaviors, and test results among women tested for HIV at public sites in Florida. Additionally, it compares these characteristics by HIV testing site type among pregnant women. Multivariable logistic regression was used to estimate the adjusted odds ratios (AOR) and associated 95\% confidence intervals for the outcome variables of risk behaviors, previous testing, and positive HIV test results.

Of the total 209,954 records, 184,037 were from women not currently pregnant, of which 87,569 (45.6\%) were among non-Hispanic Blacks (NHBs), 47,926 (26.0\%) 
non-Hispanic Whites (NHWs), and 41,117 (22.3\%) Latinas. Women who reported previous HIV testing had decreased odds of being Latina compared to NHW women (AOR 0.90; 95\% confidence interval [CI] 0.87, 0.94), and testing event results indicate that foreign-born Latina women were significantly less likely to report partner risk (AOR 0.42 ; $95 \%$ CI: $0.40-0.54$ ) than US-born Latina women. Of the 24,863 records of pregnant women, 10,199 (41.1\%) were among Latinas, 6,796 (27.4\%) were among NHB, and 6,631 (26.7\%) were among NHW. The testing records indicated that Latina and NHB women had decreased odds of reporting partner risk than NHW women (Latina: AOR 0.20; 95\% CI: 0.14-0.28; and NHB: AOR 0.14; 95\% CI: 0.10-0.21), and records of women tested in prisons/jails had higher odds of reporting previous HIV testing compared to prenatal care sites (AOR 1.86; 95\% CI: 1.03-3.39).

Reported risk behaviors varied by race/ethnicity and Latina country of origin. Knowledge of these differences can enhance current testing and prevention strategies for women, and aid in targeting HIV prevention messaging, program decision-making, and allocation of resources, corresponding to the central approach of High Impact Prevention and the National HIV/AIDS Strategy. 


\section{TABLE OF CONTENTS}

CHAPTER

PAGE

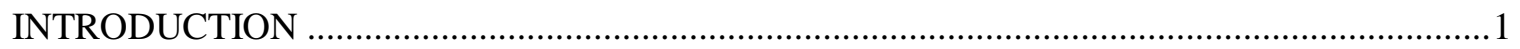

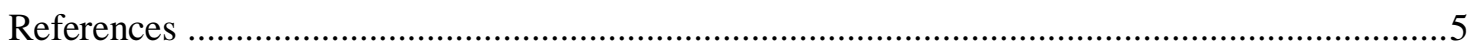

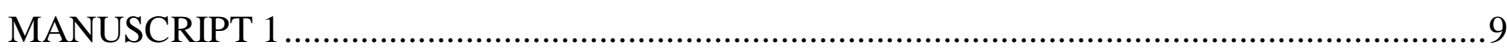

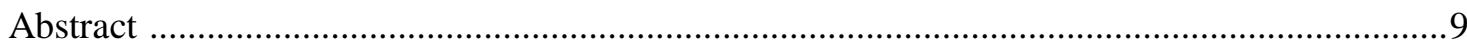

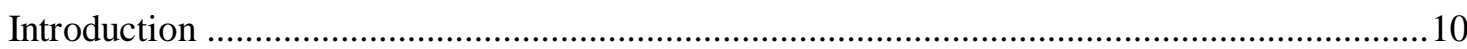

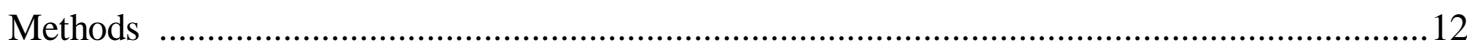

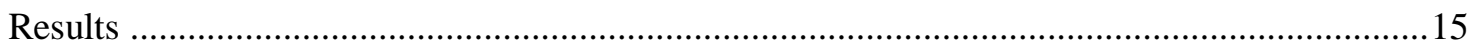

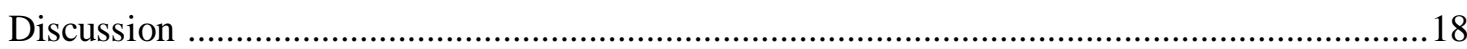

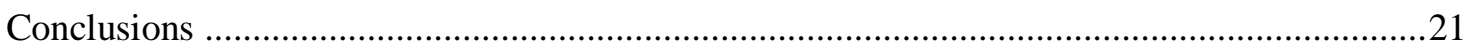

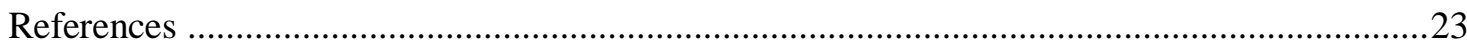

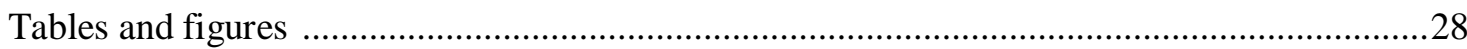

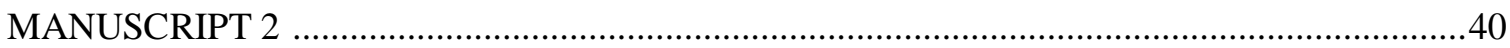

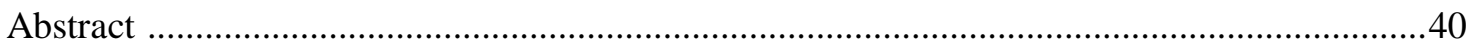

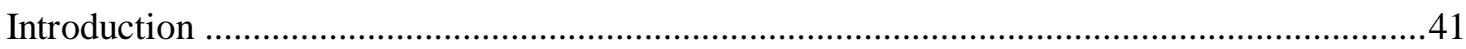

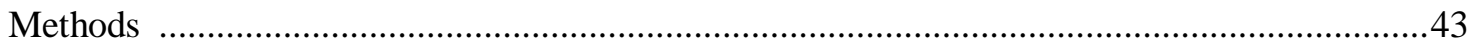

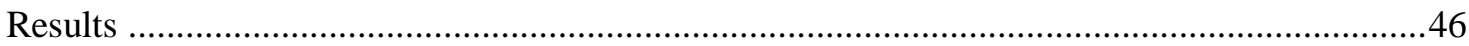

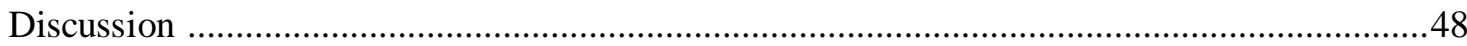

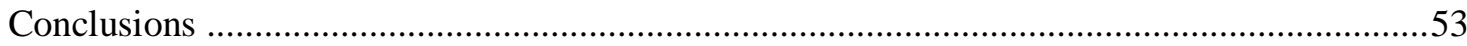

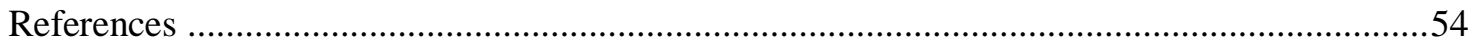

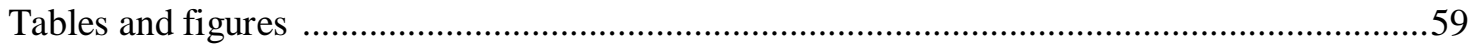

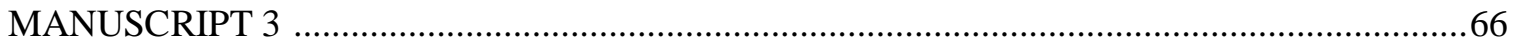

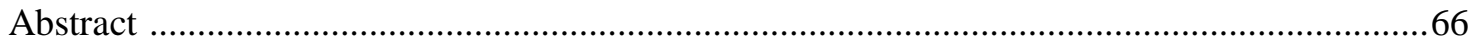

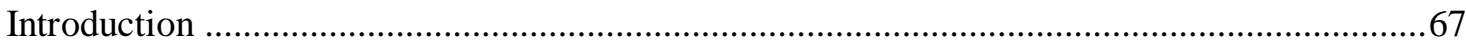

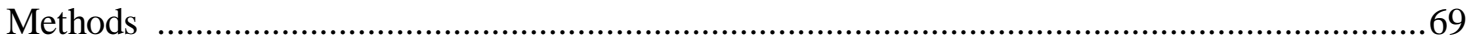

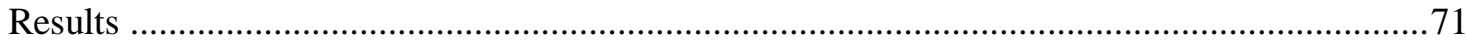

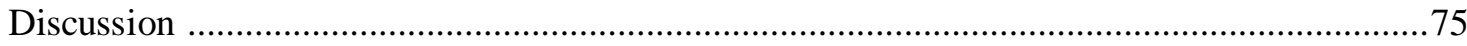

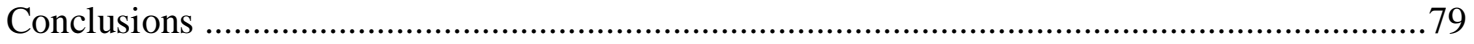

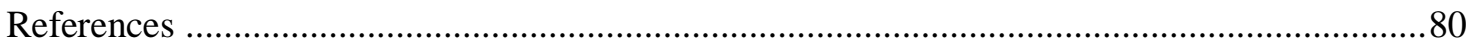




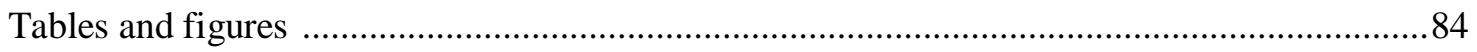

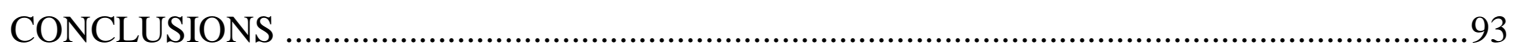

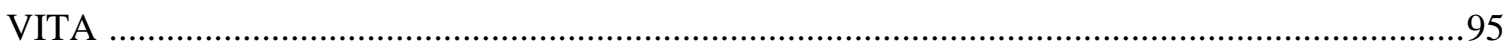




\section{ABBREVIATIONS AND ACRONYMS}

\begin{tabular}{|c|c|}
\hline AIDS & Acquired immunodeficiency syndrome \\
\hline $\mathrm{AOR}$ & Adjusted odds ratio \\
\hline $\mathrm{CDC}$ & Centers for Disease Control and Prevention \\
\hline $\mathrm{CI}$ & Confidence interval \\
\hline $\mathrm{Co}$ & Colombia \\
\hline $\mathrm{Cu}$ & Cuba \\
\hline DR & Dominican Republic \\
\hline EHARS & Enhanced HIV/AIDS Reporting System \\
\hline Es & El Salvador \\
\hline FBL & Foreign-born Latinas \\
\hline $\mathrm{Gu}$ & Guatemala \\
\hline HIV & Human immunodeficiency virus \\
\hline HIP & High Impact Prevention \\
\hline Ho & Honduras \\
\hline IDU & Injection drug user \\
\hline IRB & Institutional Review Board \\
\hline NHAS & National HIV/AIDS Strategy \\
\hline NHB & Non-Hispanic black \\
\hline NHW & Non-Hispanic white \\
\hline $\mathrm{Ni}$ & Nicaragua \\
\hline $\mathrm{Me}$ & Mexico \\
\hline MSM & Men who have sex with men \\
\hline OR & Odds ratios \\
\hline OCA & Other Central American \\
\hline
\end{tabular}




$\begin{array}{ll}\text { OSA } & \text { Other South American } \\ \text { Pe } & \text { Peru } \\ \text { PR } & \text { Puerto Rico } \\ \text { PrEP } & \text { Pre-exposure prophylaxis } \\ \text { STD } & \text { Sexually transmitted disease } \\ \text { US } & \text { United States } \\ \text { USBL } & \text { US-born Latinas } \\ \text { Ve } & \text { Venezuela }\end{array}$




\section{INTRODUCTION}

The demographics of the HIV epidemic in the United States have changed over the years; HIV infection now affects more women and members of ethnic/racial minority populations than in previous years (Institute of Medicine, 2001; Centers for Disease Control and Prevention [CDC], 2016a). Although Latinos make up approximately $17 \%$ of the US population, they make up about $24 \%$ of all newly diagnosed HIV infections (United States Census Bureau, 2015; CDC, 2016a). In 2014, the incidence of HIV among Latino men was more than triple the rate among non-Hispanic white (NHW) men (37.4 cases per 100,000 vs. 10.8 cases per 100,000), and rates among Latina women and NHW women demonstrate a similar disparity ( 5.3 cases per 100,000 vs. 1.6 cases per 100,000$)$ (CDC, 2016a). Given these incidence rates, it is particularly important that HIV risk and testing behaviors among this population be examined.

Another notable change in the US HIV epidemic is the decline in the number of perinatal infections (188 in 2010 and 86 in 2015). Nevertheless, the prevalence of female adults and adolescents living with diagnosed HIV infection continues to rise (163.8 per 100,000 in 2010 and 171.0 per 100,000 in 2015), and it is estimated that 8,500 women living with HIV give birth every year (CDC, 2016b). As there continue to be HIVpositive women of childbearing age, it is important to continue robust HIV prevention efforts for this population (Nesheim et al., 2012). Evaluation of HIV testing records among pregnant and non-pregnant women can help to identify disparities in HIV risk and testing behaviors in order to better inform current HIV prevention strategies. 
Latinos living in the US are culturally diverse, and differ in national origin, mode of HIV transmission, HIV risk behaviors, risk perception, use of prevention services, and timeliness of HIV testing, which have been found to vary by race/ethnicity and country of birth (CDC, 2007; CDC, 2013a; Espinosa et al., 2007). Many factors, including acculturation, culture, and socioeconomic status may explain these disparities in incidence rates (Marin, 2003; CDC, 2008; Gonzalez-Guarda et al., 2011). In addition, studies have identified differences concerning risk behaviors, between foreign-born Latinos (FBL) and US-born Latinos (USBL), but have limited information for women from diverse Latin countries of origin (Kaiser Family Foundation, 2006; CDC, 2007, Grieco, 2009; CDC, 2013a, Chandra, Billioux, Copen \& Sionean, 2012; CastilloMancilla et al., 2012, Sionean, 2012; Rios-Ellis et al., 2008, Dixon, Antoni, Peters \& Saul, 2001; Dixon, Peters \& Saul, 2003; Zambrana, Cornelius, Boykin \& Lopez, 2004; Moreno, Morrill \& El-Bassel, 2011). Due to limitations of previous studies, there is also a need to study risk factors and HIV testing behaviors among Latinas by taking into account country of birth and utilizing a more diverse sample of Latinas living in the US.

The Centers for Disease Control and Prevention (CDC) recommends that all individuals, aged 13-64 years of age, be screened on an "opt out" basis (consent is inferred unless the patient declines testing) for HIV infection at all health care settings as part of routine medical care. Persons at high-risk for HIV infection should be screened at least once annually (CDC, 2006). Both the CDC's "Guide for HIV Testing in Nonclinical Settings" and "Revised Guidelines for HIV Counseling, Testing, and Referral" also emphasize the importance of early knowledge of HIV status and increasing the accessibility and availability of HIV testing services (CDC, 2016c; CDC, 2001). HIV 
testing is the central step in both the HIV prevention continuum and HIV care continuum, which collectively create a framework for monitoring and evaluating HIV program performance (The White House Office of the Press Secretary, 2013; McNairy \& El-Sadr, 2014). HIV testing also creates opportunities to link HIV-positive and HIV-negative people to appropriate care and prevention services. For an HIV-positive person, this means linkage to medical care, appropriate antiretroviral therapy (ARV), and prevention services leading to a suppressed viral load and lower probability of transmitting HIV to sex partners (CDC, 2001; CDC, 2011; Hall, Walker, Shah \& Belle, 2012; Marks et al., 2005). Furthermore, recommendations emphasize routine HIV screening as part of prenatal care (CDC, 2001b).

Despite the CDC report that HIV testing rates have increased from 2000 to 2010 (CDC, 2013b), the National HIV Behavioral Surveillance data indicate that only $60.7 \%$ of Latinos report having ever been tested for HIV compared to $70.2 \%$ among NHWs and $80 \%$ of NHBs (CDC, 2015). Additionally, Latinos with HIV infection are more likely to be tested late in their HIV infection compared with NHWs (CDC, 2013c; CDC, 2003; Chen, Gallant \& Page, 2012; Sheehan, Trepka \& Dillion, 2014). Furthermore, even with evidence that regimens of antiretroviral therapy have significantly reduced rates of mother-to-child transmission of HIV, studies demonstrate that opportunities to prevent transmission still exist to enhance HIV testing, care and treatment of HIV-infected pregnant women, and understanding birth trends and patterns of care among these women (Trepka et al., 2017; Moyer, 2013; Sansom et al., 2007; McKenna and Hu, 2007; Nesheim et al., 2012). Improved testing strategies and early identification of HIV 
infection among women can improve HIV-related outcomes along the HIV care continuum including linkage to care, retention in care, and viral load suppression and further reduce mother-to-child transmission of HIV (CDC, 2013c; Gant et al., 2014, Nesheim et al. 2012).

The use of a large data set inclusive of a diverse sample of Latinas representing all Latin countries of origin was not found in previous literature. This study utilized a large state-wide data set that encompassed a diverse sample of Latinas, to identify HIV risk differences by race/ethnicity, US-born versus foreign-born status among Latinas, and by Latina country of birth. The overall objective of this study was to characterize the risk behaviors, testing behaviors, and HIV test results among all women who tested for HIV at public sites in Florida, a state with a diverse Latina community, to compare these characteristics by HIV testing site type for pregnant women and to possibly understand motivations for receipt of these services. The objective was accomplished through three separate studies. The first study aimed to differentiate HIV risk behaviors among women tested at publicly funded HIV testing sites in Florida, and to compare reported risk behaviors, including personal and partner risk, among women by race/ethnicity, foreignbirth status (nativity) among Latinas, and country of birth among Latinas. The second study aimed to compare HIV testing behaviors and outcomes between Latina women and women in other racial/ethnic groups tested at publicly funded sites in Florida, in order to determine if HIV testing activities are reaching the populations disproportionately affected by HIV. The third and final study aimed to identify reported HIV risk behaviors, testing behaviors, and demographics of pregnant women tested at publicly funded sites in 
Florida, and to compare these characteristics by HIV testing site type. In addition, the outcomes of this study can guide practices for regular monitoring and evaluation of HIV prevention, testing, and care services provided to women in the State of Florida.

\section{References}

Castillo-Mancilla, J., Allshouse, A., Collins, C., Hastings-Tolsma, M., Campbell, T. B., \& MaWhinney, S. (2012). Differences in sexual risk behavior and HIV/AIDS risk factors among foreign-born and US-born Hispanic women. Journal of Immigrant Minority Health, 14(1), 89-99.

CDC. (2001a). Revised Guidelines for HIV Counseling, Testing and Referral. Morbidity and Mortality Weekly Report, 50(RR19), 1-58. Retrieved from http://www.cdc.gov/mmwr/preview/mmwrhtml/rr5019a1.htm.

CDC. (2001b). Revised recommendations for HIV screening of pregnant women. Morbidity and Mortality Weekly Report, 50(RR19), 59-86. Retrieved from https://www.cdc.gov/mmwr/preview/mmwrhtml/rr5019a2.htm.

CDC. (2003). Late versus early testing of HIV - 16 sites, United States 2000 - 2003. Morbidity and Mortality Weekly Report, 52(25), 581-586. Retrieved from http://www.cdc.gov/mmwr/preview/mmwrhtml/mm5225a2.htm.

CDC. (2006). Revised recommendations for HIV testing of adults, adolescents, and pregnant women in health-care settings. Morbidity and Mortality Weekly Report, 55(RR14), 1-17. Retrieved from http://www.cdc.gov/mmwr/pdf/rr/rr5514.pdf.

CDC. (2007). HIV/AIDS among Hispanics-United States, 2001-2005. Morbidity and Mortality Weekly Report. 56(40):1052-1057. Retrieved from https://www.cdc.gov/mmwr/preview/mmwrhtml/mm5640a4.htm.

CDC. (2008). HIV counseling and testing among Hispanic adolescents and adults in the United States, Puerto Rico, and the U.S. Virgin Islands, 2005. Retrieved from http:///www.hivdent.org/_cdc_/2012/2005_HIV_CT_Report.pdf.

CDC. (2011). Vital signs: HIV prevention through care and treatment - United States. Morbidity and Mortality Weekly Report, 60(47), 1618-1623. Retrieved from http://www.cdc.gov/mmwr/preview/mmwrhtml/mm6047a4.htm.

CDC. (2013a). HIV Surveillance Report, 2011, 23. Retrieved from https://www.cdc.gov/hiv/pdf/statistics_2011_HIV_Surveillance_Report_vol_23.pdf. 
CDC. (2013b). HIV testing trends in the United States, 2000-2011. Retrieved from http://www.cdc.gov/hiv/pdf/testing_trends.pdf.

CDC. (2013c). Monitoring selected national HIV prevention and care objectives by using HIV surveillance data-United States and 6 dependent areas-2011. HIV Surveillance Supplemental Report, 18(5). Retrieved from http://www.cdc.gov/hiv/pdf/2011_monitoring_hiv_indicators_hssr_final.pdf.

CDC. (2015). HIV infection, risk, prevention, and testing behaviors among heterosexuals at increased risk of HIV infection-National HIV Behavioral Surveillance, 20 U.S. Cities, 2013. HIV Surveillance Special Report, 13. Retrieved from http://www.cdc.gov/hiv/pdf/library/reports/surveillance/cdc-hivHSSR_NHBS_HET_2013.pdf

CDC. (2016a). HIV Surveillance Report, 2015, 27. Retrieved from http://www.cdc.gov/hiv/library/reports/hiv-surveillance.html.

CDC. (2016b). HIV Among Pregnant Women, Infants, and Children. Retrieved from https://www.cdc.gov/hiv/group/gender/pregnantwomen/index.html.

CDC. (2016c). Implementing HIV Testing in nonclinical settings. Retrieved from https://www.cdc.gov/hiv/pdf/testing/cdc_hiv_implementing_hiv_testing_in_nonclinical_s ettings.pdf.

Chandra, A., Billioux, V. G., Copen, C. E., \& Sionean, C. (2012). HIV risk-related behaviors in the United States household population aged 15 - 44 years: Data from the national survey of family growth, 2002 and 2006-2010. National Health Statistics Reports.

Chen, N.E., Gallant, J.E., \& Page, K.R. (2012). A systematic review of HIV/AIDS survival and delayed diagnosis among Hispanics in the United States. Journal of Immigrant and Minority Health, 14(1), 65-81.

Dixon, D., Antoni, M., Peters, M., \& Saul, J. (2001). Employment, social support, and HIV sexual-risk behavior in Puerto Rican women. AIDS and Behavior, 5(4), 331.

Dixon, D., Peters, M., \& Saul, J. (2003). HIV sexual risk behavior among Puerto Rican women. Health Care for Women International, 24(6), 529.

Espinoza, L., Hall, I., Hardnett, F., Selik, R. M., Ling, Q., \& Lee, L. M. (2007). Characteristics of persons with heterosexually acquired HIV infection, United States 1999-2004. American Journal of Public Health, 97(1), 144. 
Gant, Z., Bradley, H., Hu, X., Skarbinski, J., Hall, I., \& Lansky, A. (2014). Hispanics or Latinos living with diagnosed HIV: progress along the continuum of HIV care - United States, 2010. Morbidity and Mortality Weekly Report, 63(40), 886-890. Retrieved from http://www.cdc.gov/mmwr/preview/mmwrhtml/mm6340a2.htm.

Gonzalez-Guarda, R. M., Vasquez, E. P., Urrutia, M. T., Villarruel, A. M., \& Peragallo, N. (2011). Hispanic women's experiences with substance abuse, intimate partner violence, and risk for HIV. Journal of Transcultural Nursing, 22(1), 46-54.

Grieco, Elizabeth M. 2009. Race and Hispanic Origin of the Foreign-Born Population in the United States: 2007, American Community Survey Reports, ACS-11, U.S. Census Bureau, Washington, DC.

Hall, H., Walker, F., Shah, D., \& Belle, E. (2012). Trends in HIV diagnosis and testing among US adolescents and young adults. AIDS and Behavior, 16(1), 36-43.

Institute of Medicine. (2001). Individuals and families: Models and interventions. Health and behavior: The interplay of biological, behavioral and societal influences (pp. 183). Washington: National Academy of Press.

Kaiser Family Foundation. (2006). Latinos and HIV/AIDS. HIV/AIDS policy fact sheet. Retrieved, 2012, from http://www.latinoaids.org/docs/latinas_and_hiv.pdf.

Marks, G., Crepaz, N., Senterfitt, J. W., \& Janssen, R. S. (2005). Meta-analysis of highrisk sexual behavior in persons aware and unaware they are infected with HIV in the United States: Implications for HIV prevention programs. Journal of Acquired Immune Deficiency Syndromes, 39(4), 446-453.

Marin, B. V. (2003). HIV prevention in the Hispanic community: Sex, culture, and empowerment. Journal of Transcultural Nursing, 14(3), 186-192.

McNairy, M., \& El-Sadr, W. (2014). A paradigm shift: focus on the HIV prevention continuum. Journal of Clinical Infectious Disease, Supplement 1, S12-S15. Retrieved from http://cid.oxfordjournals.org/content/59/suppl_1/S12.full.pdf+html.

McKenna, M., \& Hi, X. (2007). Recent trends in the incidence and morbidity that are associated with perinatal human immunodeficiency virus infection in the United States. American Journal of Obstetrics and Gynecology, 197(3), S10-S16.

Moreno, C. L., Morrill, A. C., \& El-Bassel, N. (2011). Sexual risk factors for HIV and violence among Puerto Rican women in New York City. Health \& Social Work, 36(2), 87-97.

Moyer, V. (2013). Screening for HIV: U.S. preventive services task force recommendation statement. Annals of Internal Medicine, 159(1), 51-60. Retrieved from http://annals.org/aim/article/1700660/screening-hiv-u-s-preventive-services-task-forcerecommendation-statement. 
Nesheim, S., Taylor, A., Lampe, M., Kilmarx, P., Harris, L., Whitmore, S., Griffith, J., Thomas-Proctor, M., Fenton, K., \& Mermin, J. (2012). A framework for elimination of perinatal transmission of HIV in the United States. Pediatrics, 130(4), 738-744. Retrieved from /content/130/4/738.full.html.

Rios-Ellis, B., Frates, J., D'Anna, L., Dwyer, M., Lopez-Zetina, J., \& Ugarte, C. (2008). Addressing the need for access to culturally and linguistically appropriate HIV/AIDS prevention for Latinos. Journal of Immigrant Minority Health, 10(5), 445-460.

Sansom, S., Harris, N., Sadek, R., Lampe, M., Ruffo, N., \& Fowler, M. (2007). Toward elimination of perinatal human immunodeficiency virus transmission in the United States: effectiveness of funded prevention programs, 1999-2001. American Journal of Obstetrics and Gynecology, 197(3), S90-S95.

Sheehan, D., Trepka, M., \& Dillion, F. (2014). Latinos in the United States on the HIV/AIDS care continuum by birth country/region: a systematic review of the literature. International Journal of STD \& AIDS, 26(1), 1-12. Retrieved from http://std.sagepub.com/content/26/1/1.full.pdf+html.

Sionean, C., Le, B.C., Hageman, K., Oster, A.M., Wejnert, C., Hess, K.L., \& Paz-Bailey, G. (2014). HIV risk, prevention, and testing behaviors among heterosexuals at increased risk for HIV infection--National HIV Behavioral Surveillance System, 21 U.S. cities, 2010. Morbidity and Mortality Weekly Report Surveillance Summary, 63(14), 1-39. Retrieved from http://www.ncbi.nlm.nih.gov/pubmed/25522191.

The White House Office of the Press Secretary. (2013). FACT SHEET: Accelerating improvements in HIV prevention and care in the United States through the HIV care continuum initiative. Retrieved from http://www.whitehouse.gov/the-press-

office/2013/07/15/fact-sheet-accelerating-improvements-hiv-prevention-and-care-unitedstat.

Trepka, M., Mukherjee, S., Beck-Sagué, C., Maddox, L., Fennie, K., Sheehan, D., Prabhakar, M., Thompson, D., \& Lieb, S. (2017). Missed opportunities for prevention perinatal transmission of human immunodeficiency virus, Florida, 2007-2014. Southern Medical Journal, 110(2), 1-13.

United Stated Census Bureau. (2015). Population Estimates. Retrieved December 2016 from http://factfinder.census.gov/bkmk/table/1.0/en/PEP/2014/PEPASR6H?slice=hisp hisp!ye ar est72014.

Zambrana, R. E., Cornelius, L. J., Boykin, S. S., \& Lopez, D. S. (2004). Latinas and HIV/AIDS risk factors: Implications for harm reduction strategies. American Journal of Public Health, 94(7), 1152-1158. 


\section{MANUSCRIPT 1}

(C) Copyright 2016

Taveras, J., Trepka, M., Khan, H., Madhivanan, P., Gollub, E., Devieux, J. (2016). HIV risk behaviors among Latina women tested for HIV in Florida by country of birth, 2012. Journal of Immigrant and Minority Health, 18(5), 1104-1114. Retrieved from http://link.springer.com/article/10.1007/s10903-015-0260-7?no-access=true.

Abstract

Objective: Latina women in the United States (US) are disproportionately affected by human immunodeficiency virus (HIV) infection. Data are limited on the risk differences in HIV among Latinas by country of birth. This paper describes the risk behaviors among Latina women tested for HIV at public sites in Florida. Methods: Multivariate logistic regression was used to assess the demographic characteristics associated with the report of specific risk behaviors. Results: Results indicate that foreign-born Latina women were significantly less likely to report partner risk (adjusted odds ratio [AOR]: 0.46; $95 \%$ confidence interval [CI]: 0.40-0.54) than US-born Latina women.

Conclusion: Reported risk behaviors varied by race/ethnicity, US-born versus foreignborn status, and by Latina country of origin. Knowledge of these differences can aid in targeting HIV prevention messaging, program decision-making, and allocation of resources, corresponding to the central approach of High Impact Prevention (HIP) and the National HIV/AIDS Strategy (NHAS).

KEYWORDS: Latinas, Foreign-born, HIV, Risk behaviors, High Impact Prevention 


\section{Introduction}

The demographics of the HIV epidemic in the United States have changed over the years; HIV infection now affects more women and members of ethnic/racial minority populations than ever before (Institute of Medicine, 2001; CDC, 2012). Although Latinos make up to $16 \%$ of the US population, they account for $21 \%$ of all new HIV infections (CDC, 2013a). The incidence of HIV among Latino men is more than double the rate among non-Hispanic white (NHW) men (45.5 cases per 100,000 vs. 14.2 cases per 100,000), and the HIV incidence among Latina women is three-fold higher than NHW women (8.0 cases per 100,000 vs. 2.6 cases per 100,000) (CDC, 2012).

Many factors, including acculturation, culture, and socioeconomic status may explain these disparities in incidence rates (Marin, 2003; CDC, 2008; Gonzalez-Guarda et al., 2011). When examining HIV risk behaviors, in relation to race/ethnicity, ambiguous or conflicting results have been reported. A study published by Brown et al., in 2007, examined recent (12-month recall) high-risk behaviors among US women aged 18 to 49 years and reported more risk behaviors among non-Hispanic black (NHB) and Latina women compared to NHW women, although none of these differences was significant (Brown, Taylor, Mulatu \& Scott, 2007). Latina women, however, reported significantly fewer HIV-related sexual risk behaviors but significantly more HIV riskrelated drug behaviors (these include illicit drug injection, crack cocaine use or crystal meth use in the past year) than NHB women (Chandra, Billioux, Copen \& Sionean, 2012). Compared to NHW women, Latina women are less likely to become infected with 
HIV through injection drug use, although modes of transmission have been shown to vary by country of birth (Kaiser Family Foundation, 2006; CDC, 2007).

Forty percent of US Latinos are foreign-born, and more than half of all HIV cases among Latinas, for which country of birth data were available, are among Latinas born outside the continental US, primarily from Cuba, Puerto Rico, and Central America (Grieco, 2009; CDC, 2013b). Though these data suggest a disproportionate impact on foreign-born Latinas, some studies suggest that foreign-born Latinas (FBL) have fewer risk behaviors than US-born Latinas (USBL) (Chandra, Billioux, Copen \& Sionean, 2012; Castillo-Mancilla et al., 2012). Among Latina women, ages 15 - 44 years, USBL reported significantly higher percentages of five or more opposite-sex partners, treatment for STDs, and HIV risk-related behaviors (Chandra, Billioux, Copen \& Sionean, 2012; Rios-Ellis et al., 2008). Also much of the published data on Latinas and HIV risk behaviors focuses primarily on women of Mexican and Puerto Rican descent (Dixon, Antoni, Peters \& Saul, 2001; Dixon, Peters \& Saul, 2003; Zambrana, Cornelius, Boykin \& Lopez, 2004; Moreno, Morrill \& El-Bassel, 2011). These studies have identified differences concerning risk behaviors, between FBL and USBL, but have been limited and not inclusive of all Latin countries of origin.

Latinos living in the US are culturally diverse, and differ in national origin, mode of HIV transmission, HIV behavioral risk factors, perception of risk, use of prevention services, and timeliness of HIV testing which have been found to vary by race/ethnicity and country of birth (CDC, 2007; CDC, 2013; Espinosa et al., 2007). Due to limitations of previous studies, there is a need to study risk factors and HIV testing behaviors among 
Latinas by taking into account country of birth and utilizing a more representative sample of Latinas living in the US.

The objectives of this study were to characterize HIV risk behaviors among women tested at publicly funded HIV testing sites in Florida, a state with a diverse Latina community, and to compare reported risk behaviors, including personal and partner risk, among women by race/ethnicity and by foreign-birth status among Latinas, and by country of birth among Latinas.

\section{Methods}

\section{$\underline{\text { Study design and population }}$}

This was a cross-sectional study using de-identified data from the Florida HIV Counseling and Testing database, which included demographic and risk behavior information from all records of women tested for HIV in publicly-funded HIV counseling and testing sites in Florida. These data were recorded on the Department of Health 1628 Testing and Counseling Forms and completed by trained counselors, who collect demographic and risk behavior information from persons voluntarily testing for HIV. The variables captured included self-reported risk behaviors during the 12 months prior to testing, country of birth, race, ethnicity, gender, previous HIV testing, and current testing site. This information was sent to the Florida Department of Health Counseling, Testing and Linkage data team, where it was entered into a database. The dataset for the current study included HIV publicly-funded testing events for women, 13 years of age and older, testing for HIV, in the state of Florida during 2012. 


\section{Inclusion Criteria}

A total of 184,037 testing event records from women were included in the analysis. Because records were de-identified, it is possible that some women were tested more than once in the given year and thus may be represented more than once in the dataset. However, it was not possible to identify any duplicate records. For ease of reading in this manuscript, results are reported using the terminology of "women" as opposed to "testing events". Of the total women, 41,117 were Latinas; 47,926 NHW; 87,569 NHB; 1,753 belonged to other racial/ethnic group and 5,672 had missing racial/ethnic information. Women that responded "yes" to current pregnancy $(24,836)$ were excluded from the analysis because these HIV tests may have likely been driven by routine testing as opposed to testing because of perceived risk of HIV infection. Records from transgender individuals were excluded from the sample because of small numbers (59 Latina, 57 NHW, 120 NHB, 3 other race/ethnicity, and 3 missing race/ethnicity). Sex with only women in the past 12 months was not an HIV risk factor analyzed in this study, since the majority of HIV transmission among women is through heterosexual exposure and case reports of female-to-female transmission are rare (CDC, 2012).

\section{Classification of risk: variables used in this study}

Great diversity exists in approaches that have been used to measure the degree of HIV risks (Brown et al., 2007; Wallace et al., 2011; Blackstock et al., 2010; Bond, Lauby \& Batson, 2005; Djokic et al., 2009; Renzi et al., 2004; Vargo et al., 2004; Wiggers et al., 2003; Whyte, 2005; Catania et al., 1995; Bishop, Kok \& Chan, 1998; Fitterling et al., 1993; Pathela et al., 2006; Chirgwin et al., 1991; Hong et al., 2011; Susser, Desvarieux \& 
Wittkowski, 1998). A study published by Hong and colleagues in 2010, utilized an index of risk by exposure category: partner risk exposure versus personal risk exposure, which was used as a model for risk definition in this study. Personal risk was defined as any factor which would place an individual at-risk for HIV based on their own risk behaviors or activities. Partner risk was defined as having vaginal or anal sex with a partner who had an increased risk of HIV (Table 1). In addition, each individual risk behavior was analyzed. The questions included vaginal/anal sex with a man and did not separate the two sex acts. Therefore, it was not possible to analyze vaginal sex and anal sex separately.

$\underline{\text { Statistical analysis }}$

Descriptive statistics and other preliminary analyses were first performed considering age, race/ethnicity, and previous HIV testing and risk factors listed in Table 1. All of the variables were categorical except age, which was collected in years and then recoded into categories. Bivariate analyses were performed to determine if there were differences in age, HIV risk factors, and testing by race/ethnicity. Further analysis was restricted to records of Latina women to compare records of Latinas born in the continental US (hereafter referred to as US-born) vs. records from Latinas born in other countries or Puerto Rico (hereafter referred to as foreign born). The bivariate analyses were repeated among foreign-born Latinas to compare risk factors by country of birth.

Controlling for age, two sets of multivariate analysis were conducted. The first set had 'personal risk behavior' as the dependent variable. The second set had 'partner risk behavior' as the dependent variable. For each set, the groups were compared three 
different ways to calculate adjusted odds ratios (AOR) and 95\% confidence intervals (CI) to examine differences in risk behaviors among women publicly tested for HIV in Florida: by 1) race/ethnicity; 2) FBL vs. USBL; and 3) Latina country of birth. Previous HIV testing history was also included as an independent variable. Clustering effects of testing site were handled through a random intercept using SAS Proc Glimmix. SAS software, version 9.3 (SAS Institute, Cary, NC 2002) was used to conduct all analyses. The Florida Department of Health and Florida International University's Institutional Review Boards (IRB) deemed this study non-human subjects research and exempt from IRB review.

Results

$\underline{\text { Sample characteristics }}$

Of the 184,037 women included in these analyses, $47.6 \%$ were NHB, $26.0 \%$ NHW, 22.3\% Latina, 3.1\% had no recorded race/ethnicity ('Missing'), and 1.0\% belonged to other race/ethnic group ('Other') (Table 2). The largest proportion of women $(44.1 \%)$ were $20-29$ years of age followed by $30-39$ years $(21.5 \%)$. Most participants $(92.6 \%)$ reported personal risk in the prior 12 months while only $5.0 \%$ reported partner risk in the prior 12 months. The most frequently reported risk was vaginal/anal sex with a male (89.4\%) followed by STD diagnosis (7.4\%), sex for drugs/money/other items (3.6\%), vaginal/anal sex with an IDU (3.1\%), injection drug use $(3.1 \%)$, and vaginal/anal sex with an HIV positive person (1.1\%). 
Race/ethnicity among HIV testing women

Significant differences between racial/ethnic groups with respect to reported risks were identified in the bivariate analyses. Personal risk was more frequently reported by NHW women than Latinas and NHB women $(92.0 \%$ vs. $90.2 \%$ and $88.6 \%$ respectively; $p<0.0001)$. Latina women reported less partner risk than NHW women $(3.1 \%$ vs. $12.3 \% ; p<0.0001)$ but reported more partner risk than NHB women $(3.1 \%$ vs. $1.9 \% ; p<0.0001)$. Compared to NHW women, all risk factors were less frequently reported by Latina women $(p<0.0001)$. However, compared with NHB women, Latina women more frequently reported vaginal/anal sex with a male (89.9\% vs. $88.3 \%$; $p<0.0001)$, injection drug use (1.4\% vs. $0.4 \% ; p<0.0001)$, vaginal/anal sex with an IDU (1.5\% vs. $0.4 \% ; p<0.0001)$, and vaginal/anal sex with an MSM $(0.8 \%$ vs. $0.7 \% ; p=$ 0.0350). Latina women tended to be older with greater proportions of those being $40-$ 49 years of age $(14.7 \%)$ and 50 years of age and over $(9.5 \%)$, as compared with NHW and NHB women (Table 2). In multivariate analysis, when controlling for age, Latina and NHB women were less likely to report both partner and personal risk than NHW women (Latina: AOR 0.38, 95\% CI: 0.35-0.41; AOR 0.85, 95\% CI: 0.80-0.89 and NHB: AOR 0.18, 95\% CI: 0.17-0.20; AOR 0.71, 95\% CI: 0.68-0.75 respectively) (Table 3). $\underline{\text { HIV testing among Latina women by US-born and foreign-born status }}$

Foreign-born Latinas tended to be older than US-born Latinas (e.g. among 40-49 year olds $18.3 \%$ vs. $10.0 \%$ and among 50 and older $12.9 \%$ vs. $4.6 \%$ ) with a mean age of 35 versus 29 years for USBL (Table 4). Univariate analysis showed no significant difference between the report of personal risk among FBL and USBL (89.9\% vs. 89.3\%; $p=0.0882$ ). However, Latina women missing a country of birth more frequently reported 
personal risk compared to FBL (92.8\% vs. $89.9 \%$; $p<0.0001)$. Partner risk was more frequently reported by USBL than FBL (6.6\% vs. $1.7 \% ; p<0.0001)$ and more frequently reported by women missing a country of birth than FBL ( $3.4 \%$ vs. $1.7 \% ; p<0.0001)$. All risk factors, with the exception of sex (vaginal or anal) with a male, were reported more frequently by USBL than FBL (Table 4). In the multivariate analysis, controlling for age, comparing records of USBL, FBL were 54\% less likely to report partner risk (AOR: 0.46; 95\% CI: 0.40-0.54) but not significantly less likely to report personal risk (AOR: 0.98; 95\% CI: 0.89-1.08) (Table 3).

$\underline{\text { HIV testing among Latina women by country of birth }}$

Latina women reported the following countries of birth: US (22.7\%), Mexico (15.9\%), Cuba (9.6\%), Colombia (5.5\%), Honduras (4.7\%), Guatemala (4.4\%), Puerto Rico (4.4\%), Nicaragua (2.6\%), Dominican Republic (2.6\%), other South American (OSA) countries (2.7\%), El Salvador (2.2\%), Peru (2.2\%), Venezuela (1.9\%), Brazil (1.0\%), and other Central American (OCA) countries (0.9\%) (Table 5). The countries of birth with the highest proportions of women 50 years and over were Colombia, Cuba, Nicaragua and Dominican Republic (26\%, 20\%, $18 \%$ and 18\% respectively) (Table 5). In the univariate analysis, USBL tended to be younger; $17.3 \%$ were $13-19$ years of age and 50.1\% were 20-29 years. Personal risk was most frequently reported among women born in El Salvador (93.7\%) and Mexico (93.6\%), while partner risk was more frequently reported by women born in the US (6.6\%) and Puerto Rico (5.9\%). Women born in Mexico and El Salvador equally reported the highest percentage (93.5\% each) of vaginal or anal sex with a male. Exchanging anal, vaginal or oral sex for drugs, money or other 
items was most frequently reported by USBL (4.4\%). USBL were more likely to report previous STD diagnosis (7.8\%), sex with an IDU (4.0\%), and injection drug use (3.8\%). Vaginal/anal sex with an HIV-positive person was most frequently reported by Puerto Rican born women (2.6\%). Vaginal/anal sex with an MSM was reported most frequently by women born in Brazil (2.0\%). Most FBL reported less partner risk and personal risk compared to USBL. However, results varied by country of birth and by specific risk subgroup. FBL born in in Mexico, El Salvador, Guatemala, Honduras, Brazil, and other Central America reported more personal risk compared to USBL (Table 5). However, after controlling for age, in the multivariate analysis, there was only one significant difference, namely between Latinas born in Mexico and USBL (AOR: 1.31; 95\% CI: 1.13-1.52) (Table 3).

\section{Discussion}

Among all women tested for HIV in Florida, the majority reported some form of personal risk, most commonly vaginal/anal sex with a man, while partner risk was less frequently reported. Latinos living in the US represent a diverse set of nationalities, ethnicities, ages, educational attainment, culture and acculturation levels. However, Latinos are often studied as a homogeneous group (Espinosa et al., 2007; Kinsler et al., 2009; Vega et al., 2015). Results indicate differences in reported risk behaviors by race/ethnicity, and among Latinas by country of birth, especially when examining specific reported risk behaviors. Partner risk was less frequently reported than personal risk for all women testing for HIV in Florida even though most HIV-infected women in Florida reported exposure through high risk heterosexual contact (Florida Department of 
Health, 2013). However, many women are unaware of their partner's risk behaviors or may have misconceptions about partner risk (Cianelli et al., 2010; Abel \& Chambers, 2004; Essien, Meshack \& Ross, 2002). It is likely that partner risk is more prevalent than what these findings report.

Latina and NHB women reported less personal and partner risk than NHW women although risk subgroups did vary. This finding differs from prior literature where it was found that Latina and NHB women had higher risk behaviors than NHW (Brown et al., 2007; Chandra et al., 2012). These differences could be explained by varying definitions of risk including the capturing of recent versus lifetime risks (Brown et al., 2007; Chandra et al., 2012). It is important to define risks similarly to improve the ability to make comparisons between samples. Latina women were also seeking HIV testing services at a later age than NHW and NHB women. This could mean that HIV testing among Latinas is related to acculturation, defined as 5 or more years living in the United States, which may explain a delay in HIV testing behaviors and the older age of Latinas at the time of HIV testing (Kinsler et al., 2009).

Results of comparisons among US-born and foreign-born Latinas also provided more insights into the prevalence of certain risk behaviors. USBL were more likely than FBL to report the most risk behaviors, which agrees with previous literature (Chandra et al., 2012; Castillo-Mancilla et al., 2012; Rios-Ellis et al., 2008). However, reported risk factors vary depending on country of birth (CDC, 2007; Espinoza et al., 2007). There may be a greater acceptance of FBL to report less stigmatizing risks, such as sex with a male, or an overall misunderstanding of risk among this group of women (Essien, 
Meshack \& Ross, 2002). Significant differences by country of birth were identified when further examining partner risk subgroups. Women born in Brazil were most likely to report vaginal or anal sex with an MSM, and Puerto Rican-born women were the most likely to report vaginal or anal sex with an IDU. Previous literature has also suggested higher MSM activity in South America and Cuba, IDU in Puerto Rico, and high-risk heterosexual contact in Dominican Republic (Kaiser Family Foundation, 2006; CDC, 2007; Kang et al., 2009). These variations in risk factors by country of birth may be rooted in an increased awareness of partner's behavior by Latina women born in certain countries or increased prevalence of risk behaviors in these countries (Kinsler et al., 2009; Montealegre et al., 2012; Gimenez-Garcia, 2013).

This study was limited due to the use of self-report of HIV risk. Most HIVpositive women have been infected through their partner's risk such as sex with an MSM or IDU, but many are unaware of their partners' risk behavior (Abel \& Chambers, 2004). Not all women reported recent risk behaviors which may indicate delays in HIV testing after risk exposure, a lack of awareness of partners' HIV risk, and possible underreporting of HIV risk, especially partner risk (Essien, Meshack \& Ross, 2002). Underreporting may be due to stigma, feelings of shame, guilt, denial, or not being cognizant of partner's engagement in certain risk behaviors and/or partners' HIV status (GimenezGarcia, 2013).

Another limitation was that the dataset only included information on HIV testing conducted at publicly funded HIV testing sites. There may be differences in the women testing in private versus public HIV testing locations because public HIV testing requires 
no insurance. Variables such as acculturation, condom-protected sex acts, or the use of other forms of HIV prevention such as pre-exposure prophylaxis (PrEP) were also not captured. Obtaining proxy information for acculturation, such as years living in the US and preferred language, and additional prevention information may be useful in assessing HIV risk behaviors among Latinas (Kang et al., 2009). Although undocumented status is not recorded at testing sites, any form of identification could be used for voluntary HIV testing, which increases the likelihood that FBL who were not legally in the United States were included in the data.

Country of birth was missing for a notable number of records of Latina women. Compared to FBL, those with missing country of birth had reported significantly more risks overall for all risk categories except vaginal or anal sex with a male. This may suggest that this group of Latina women missing a country of birth were not foreign born or they felt at more liberty to report risk behaviors by not revealing personal identifying information. However, there is no way to confirm this with the available data set. The HIV testing data set provided de-identified records of HIV testing. Although it may be possible that some women were tested more than once in the given year, and thus may be represented more than once in the dataset, it was not possible to identify any duplicate records.

\section{Conclusions}

The results of this study add important information to improve HIV prevention and care among Latinos in Florida and assist in the three primary goals of the National HIV/AIDS Strategy (NHAS): 1) reducing the number of people who become infected 
with HIV; 2) increasing access to care and improving health outcomes for people living with HIV; and 3) reducing HIV-related health disparities (Office of National AIDS Policy, 2010). The CDC's High Impact Prevention (HIP) response to the NHAS, which targets populations at greatest risk and geographic areas hardest hit by HIV, and includes Latinos in the state of Florida (CDC, 2011). The importance of studying and increasing testing among Latinos as a HIP strategy was also highlighted by the Florida Latino AIDS Advisory group in a document titled "Test and Treat Latino HIV/AIDS in Florida" (Castillo-Mancilla et al., 2012; Florida Department of Health, 2011). Current prevention strategies for women do not consider cultural differences between Latinas from different countries of origin (Zambrana et al., 2004; CDC, 2011; Rios-Ellis et al., 2008). Examining Latinas by their country of birth, in addition to comparing US-born and foreign-born Latinas, provided a greater understanding of risk differences that were associated with the women of specific Latin countries. This new understanding can assist in tailoring effective prevention strategies for this diverse population of women. The strength of this study is that it provides proportion estimates of risk behaviors by country of birth for a diverse group of Latina women publicly testing for HIV. Diversity in the reported risks suggests that awareness of HIV risk, as much as the presence of the behavioral risk itself, may be influenced by additional factors including culture and acculturation. Measures for acculturation, such as preferred language and/or years living in the United States, in addition to prevention data (i.e. consistent condom use and use of PrEP) should be collected at publicly funded HIV testing sites as well.

HIV testing messages and services have mostly been targeted to MSM and black communities and thus may be less effective among Latinos. However, there are limited 
data on cultural variations in knowledge, beliefs and behaviors specific to Latinos (Kinsler et al., 2009; Vega et al., 2015; Gimenez-Garcia et al., 2013). Since a notable number of Latinas were missing a country of birth (16.2\%), emphasis should also be made in capturing more complete and accurate data on the DH 1628 TCF. Understanding the cultural difference of reported risks behaviors by race/ethnicity and Latino country of birth, especially around the topics of partner risk and communication, is important to guide prevention efforts and create effective HIV testing messages (Montealegre et al., 2012; Gimenez-Garcia et al., 2013; Rios-Ellis et al., 2008). A greater understanding of partner risk can increase HIV susceptibility and HIV testing behaviors among Latinas and may be a critical component to improve the reporting of risk information and increase the effectiveness of tailored, large-scale, risk reduction counseling for Latinas (Cianelli et al., 2010). Therefore, increasing partner communication is a topic that should be addressed by HIV testing messages for Latinas in Florida. Future studies should further examine the concept of partner behaviors as it relates to culture and HIV risk among Latinas.

Lastly, increased HIV testing in private medical settings is expected due to the promotion of routine HIV testing through national and state initiatives (Office of National AIDS Policy, 2010). The collection of risk and prevention behavior data should be incorporated as part of all HIV testing, regardless of funding source and routinely analyzed to enhance HIV programing and evaluation.

\section{References}

Abel, E., \& Chambers, K. (2004). Factors that influence vulnerability to STDs and HIV/AIDS among Hispanic women. Health Care for Women International, 25(8), 761780 . 
Bishop, G. D., Kok, A. J., \& Chan, R. K. W. (1998). Sexual practices among men attending an anonymous HIV testing site in Singapore. AIDS Care, Supplement 2, S167S178.

Brown, N., Taylor, E., Mulatu, M., \& Scott, W. (2007). Demographic correlates of HIV testing, high-risk behaviors, and Condom/STD consultation among a multi-ethnic sample of women. Women \& Health, 46(2/3), 59-76.

Blackstock, O. J., King, J. R., Mason R.D., Lee, C. C., \& Mannheimer, S. B. (2010). Evaluation of a rapid HIV testing initiative in an urban, hospital-based dental clinic. AIDS Patient Care and STDs, 24(12), 781-785.

Bond, L., Lauby, J., \& Batson, H. (2005). HIV testing and the role of individual- and structural-level barriers and facilitators. AIDS Care, 17(2), 125-140.

Castillo-Mancilla, J., Allshouse, A., Collins, C., Hastings-Tolsma, M., Campbell, T. B., \& MaWhinney, S. (2012). Differences in sexual risk behavior and HIV/AIDS risk factors among foreign-born and US-born Hispanic women. Journal of Immigrant Minority Health, 14(1), 89-99.

Catania, J. A., Binson, D., Dolcini, M. M., Stall, R., Choi, K., Pollack, L. M., Moskowitz, J. T. (1995). Risk factors for HIV and other sexually transmitted diseases and prevention practices among US heterosexual adults; changes from 1990 to 1992. American Journal of Public Health, 85(11), 1492-1499.

CDC. (2007). HIV/AIDS among Hispanics-United States, 2001-2005.MMWR 2007; 56(40):1052-1057. Retrieved from https://www.cdc.gov/mmwr/preview/mmwrhtml/mm5640a4.htm.

CDC. (2008). HIV counseling and testing among Hispanic adolescents and adults in the United States, Puerto Rico, and the U.S. Virgin Islands, 2005. Retrieved from http:///www.hivdent.org/_cdc_/2012/2005_HIV_CT_Report.pdf.

CDC. (2011). High-impact prevention: CDC's approach to reducing HIV infections in the United States. Retrieved from https://www.cdc.gov/hiv/pdf/policies_NHPC_Booklet.pdf

CDC. (2012). Estimated HIV incidence in the United States, 2007-2010. HIV

Surveillance Supplemental Report, 17(4). Retrieved December 2012 from http://www.cdc.gov/hiv/topics/surveillance/resources/reports/\#supplemental.

CDC. (2013a). HIV among Hispanics/Latinos in the United States and dependent areas. Retrieved January 2014 from http://www.cdc.gov/hiv/pdf/risk_latino.pdf. 
CDC. (2013b). HIV Surveillance Report, 2011, 23. Retrieved February 2013 from http://www.cdc.gov/hiv/library/reports/surveillance/2011/surveillance_Report_vol_23.ht $\mathrm{ml}$.

Chandra, A., Billioux, V. G., Copen, C. E., \& Sionean, C. (2012). HIV risk-related behaviors in the United States household population aged 15 - 44 years: Data from the national survey of family growth, 2002 and 2006-2010. National Health Statistics Reports. 58, 1-27. Retrieved from https://www.cdc.gov/nchs/data/nhsr/nhsr058.pdf.

Chirgwin, K., DeHovitz, J. A., Dillon, S., \& McCormack, W. M. (1991). HIV infection, genital ulcer disease, and crack cocaine use among patients attending a clinic for sexually transmitted diseases. American Journal of Public Health, 81(12), 1576-1579.

Cianelli, R., Villegas, N., Gonzalez-Guarda, R., Kaelber, L., \& Peragallo, N. (2010). HIV susceptibility among Hispanic women in South Florida. Journal of Community Health Nursing, 27(4), 207-215

Dixon, D., Antoni, M., Peters, M., \& Saul, J. (2001). Employment, social support, and HIV sexual-risk behavior in Puerto Rican women. AIDS and Behavior, 5(4), 331-342.

Dixon, D., Peters, M., \& Saul, J. (2003). HIV sexual risk behavior among Puerto Rican women. Health Care for Women International, 24(6), 529-543.

Djokic, D., Englund, J., Daum, R., Martin, R., Dozier, T., Potts, S., Marcinal, J. (2009). HIV knowledge and attitudes toward HIV testing of south side Chicago housing authority residents. AIDS Patient Care and STDs, 23(1), 23-28.

Espinoza, L., Hall, I., Hardnett, F., Selik, R. M., Ling, Q., \& Lee, L. M. (2007). Characteristics of persons with heterosexually acquired HIV infection, United States 19992004. American Journal of Public Health, 97(1), 144-149.

Essien, E. J., Meshack, A. F., \& Ross, M. W. (2002). Misperceptions about HIV transmission among heterosexual African-American and Latino men and women. Journal of the National Medical Association, 94(5), 304-312.

Fitterling, J. M., Matens, P. B., Scotti, J. R., \& Allen, J. S. (1993). AIDS risk behaviors and knowledge among heterosexual alcoholics and non-injecting drug users. Addiction, 88(9), 1257-1265.

Florida Department of Health. (2011). Test and Treat Latinos HIV/AIDS in Florida, Retrieved 2013 from http://www.floridahealth.gov/diseases-andconditions/aids/operations_managment/FLAAG-Response-to-NHAS.pdf

Florida Department of Health. (2013). HIV/AIDS among Minorities in Florida, Retrieved 2015 from http://www.floridahealth.gov/diseases-and-conditions/aids/surveillance/epiprofiles/epiprof-minorities-2012-revised.pdf 
Gimenez-Garcia, C., Ballester-Arnal, R., Gil-Llario, M. D., Cardenas-Lopez, G., \& DuranBaca, X. (2013). Culture as an influence on the perceived risk of HIV infection: A differential analysis comparing young people from Mexico and Spain. Journal of Community Health, 38(3), 434-442.

Gonzalez-Guarda, R. M., Vasquez, E. P., Urrutia, M. T., Villarruel, A. M., \& Peragallo, N. (2011). Hispanic women's experiences with substance abuse, intimate partner violence, and risk for HIV. Journal of Transcultural Nursing, 22(1), 46-54.

Grieco, Elizabeth M. 2009. Race and Hispanic Origin of the Foreign-Born Population in the United States: 2007, American Community Sur-vey Reports, ACS-11, U.S. Census Bureau, Washington, DC.

Hong, N., Wolfe, M. I., Dat, T. T., McFarland, D. A., Lamb, M. L., Thang, N. T., Del Rio, C. (2011). Utilization of HIV voluntary counseling and testing in Vietnam: An evaluation of 5 years of routine program data for national response. AIDS Education and Prevention, 23(3), 30-48.

Institute of Medicine. (2001). Individuals and families: Models and interventions. Health and behavior: The interplay of biological, behavioral and societal influences (pp. 183). Washington: National Academy of Press.

Kaiser Family Foundation. (2006). Latinos and HIV/AIDS. HIV/AIDS policy fact sheet. Retrieved, 2012, from http://www.latinoaids.org/docs/latinas_and_hiv.pdf

Kang, S., Deren, S., Mino, M., \& Cortes, D. (2009). Biculturality and HIV-risk behaviors among Puerto Rican drug users in New York City. Substance Use and Misuse, 44(4), 578592.

Kinsler, J., Lee, S., Sayles, J., Newman, P. A., Diamant, A., \& Cunninfham, W. (2009). The impact of acculturation on utilization of HIV prevention services and access to care among an at-risk Hispanic population. Journal of Health Care for the Poor and Underserved, 20(4), 996-1011.

Marin, B. V. (2003). HIV prevention in the Hispanic community: Sex, culture, and empowerment. Journal of Transcultural Nursing, 14(3), 186-192.

Montealegre, J. R., Risser, J. M., Selwyn, B. J., Sabin, K., \& McCurdy, S. A. (2012). HIV testing behaviors among undocumented Central American immigrant women in Houston, Texas. Journal of Immigrant Minority Health, 14(1), 116-123.

Moreno, C. L., Morrill, A. C., \& El-Bassel, N. (2011). Sexual risk factors for HIV and violence among Puerto Rican women in New York City. Health \& Social Work, 36(2), 87-97. 
Office of National AIDS Policy. (2010). National HIV/AIDS strategy. Retrieved 2011 from http://www.whitehouse.gov/administration/eop/onap/nhas

Pathela, P., Hajat, A., Schillinger, J., Blank, S., Sell, R., \& Mostashari, F. (2006).

Discordance between sexual behavior and self-reported sexual identity: A populationbased survey of New York City men. Annals of Internal Medicine, 145(6), 416-425.

Renzi, C., Zantedeschi, E., Signorelli, C., \& NEM Group. (2004). Voluntary HIV testing in Europe. Scandinavian Journal of Public Health, 32(2), 102-110.

Rios-Ellis, B., Frates, J., D'Anna, L., Dwyer, M., Lopez-Zetina, J., \& Ugarte, C. (2008). Addressing the need for access to culturally and linguistically appropriate HIV/AIDS prevention for Latinos. Journal of Immigrant Minority Health, 10(5), 445-460.

Susser, E., Desvarieux, M., \& Wittkowski, K. M. (1998). Reporting sexual risk behavior for HIV: A practical risk index and a method for improving risk indices. American Journal of Public Health, 88(4), 671-674.

Vargo, S., Agronick, G., O'Donnell, L., \& Stueve, A. (2004). Field action report. Using peer recruitment and OraSure to increase HIV testing. American Journal of Public Health, 94(1), 29-31

Vega, M. Y., Klukas, E., Valera, E., \& Montenegro, J. (2015). The state of Latinos in the deep south: Being visible by piercing the stigma veil. New York, NY: Latino Commission on AIDS. Retrieved from https://www.latinoaids.org/publications/DeepSouthReport2015.pdf.

Wallace, S., McLellan-Lemal, E., Harris, M., Townsend, T., \& Miller, K. (2011). Why take an HIV test? Concerns, benefits, and strategies to promote HIV testing among lowincome heterosexual African American young adults. Health Education and Behavior, 38(5), 462-470.

Whyte, J. I. (2005). The measurement of HIV risk level in African American women who dwell in the southeastern United States. Journal of the Association of Nurses in AIDS Care, 16(6), 48-55.

Wiggers, L. C., De Wit, J. B., Gras, M. J., Coutinho, R. A., \& Van Den Hoek, A. (2003). Risk behavior and socio-cognitive determinants of condom use among ethnic minority communities in Amsterdam. AIDS Education and Prevention, 15(5), 430-447.

Zambrana, R. E., Cornelius, L. J., Boykin, S. S., \& Lopez, D. S. (2004). Latinas and HIV/AIDS risk factors: Implications for harm reduction strategies. American Journal of Public Health, 94(7), 1152-1158. 


\section{Tables and Figures}

Table 1. HIV risk categories

Personal risk exposure categories

Risk based on partner exposure categories

Sex (vaginal/anal) with a male Sex (vaginal/anal) with HIV positive person

Sex for drugs/money/other items (anal, vaginal or Sex (vaginal/anal) with an IDU oral)

STD diagnosis

Sex (vaginal/anal) with a MSM

Injection drug use

$\overline{\mathrm{STD}}=$ sexually transmitted disease, HIV = human immunodeficiency virus, IDU = injection drug user, MSM

$=$ man that has sex with men 
Table 2. HIV risk behaviors, previous HIV testing and demographics by race/ethnicity for women not currently pregnant

\begin{tabular}{|c|c|c|c|c|c|c|c|c|}
\hline Race/ethnicity & Total & $\begin{array}{l}\text { Latina } \\
\text { n (\%) }\end{array}$ & $\begin{array}{l}\text { NHW } \\
\text { n(\%) }\end{array}$ & $\begin{array}{l}\text { NHB } \\
\text { n }(\%)\end{array}$ & $\begin{array}{l}\text { Other } \\
\text { n }(\%)\end{array}$ & $\begin{array}{l}\text { Missing } \\
\text { n (\%) }\end{array}$ & $\begin{array}{l}\text { Latina } \\
\text { vs. NHW } \\
p \text {-value }\end{array}$ & $\begin{array}{l}\text { Latina vs. } \\
\text { NHB } \\
p \text {-value }\end{array}$ \\
\hline Total & 184,037 & $\mathrm{n}=41,117$ & $\mathrm{n}=47,926$ & $\mathrm{n}=87,569$ & $\mathrm{n}=1,753$ & $\mathrm{n}=5,672$ & & \\
\hline Mean Age (years) & 30.5 & 32.1 & 30.3 & 30.0 & 30.9 & 30.1 & & \\
\hline Age group (n) & & & & & & & $<0.0001$ & $<0.0001$ \\
\hline $13-19$ & $\begin{array}{l}24,522 \\
(13.3)\end{array}$ & $\begin{array}{l}4,379 \\
(10.7)\end{array}$ & $\begin{array}{l}6,974 \\
(14.6)\end{array}$ & $\begin{array}{l}12,084 \\
(13.8)\end{array}$ & $\begin{array}{l}202 \\
(11.5)\end{array}$ & $\begin{array}{l}883 \\
(15.6)\end{array}$ & & \\
\hline $20-29$ & $\begin{array}{l}81,231 \\
(44.1)\end{array}$ & $\begin{array}{l}16,042 \\
(39.0)\end{array}$ & $\begin{array}{l}21,103 \\
(44.0)\end{array}$ & $\begin{array}{l}40,811 \\
(46.6)\end{array}$ & $\begin{array}{l}791 \\
(45.1)\end{array}$ & $\begin{array}{l}2,484 \\
(43.8)\end{array}$ & & \\
\hline $30-39$ & $\begin{array}{l}39,605 \\
(21.5)\end{array}$ & $\begin{array}{l}10,748 \\
(26.1)\end{array}$ & $\begin{array}{l}9,698 \\
(20.2)\end{array}$ & $\begin{array}{l}17,590 \\
(20.1)\end{array}$ & $\begin{array}{l}379 \\
(21.6)\end{array}$ & $\begin{array}{l}1,190 \\
(21.0)\end{array}$ & & \\
\hline $40-49$ & $\begin{array}{l}23,158 \\
(11.5)\end{array}$ & $\begin{array}{l}6,038 \\
(14.7)\end{array}$ & $\begin{array}{l}6,182 \\
(12.9)\end{array}$ & $\begin{array}{l}10,048 \\
(11.5)\end{array}$ & $\begin{array}{l}234 \\
(13.4)\end{array}$ & $\begin{array}{l}647 \\
(11.4)\end{array}$ & & \\
\hline 50 and over & $\begin{array}{l}15,530 \\
(8.4)\end{array}$ & $\begin{array}{l}3,910 \\
(9.5)\end{array}$ & $\begin{array}{l}3,969 \\
(8.3)\end{array}$ & $\begin{array}{c}7,036 \\
(8.0)\end{array}$ & $\begin{array}{l}147 \\
(8.4)\end{array}$ & $\begin{array}{l}468 \\
(8.3)\end{array}$ & & \\
\hline
\end{tabular}




\begin{tabular}{|c|c|c|c|c|c|c|c|c|}
\hline Any personal risk & $\begin{array}{l}165,194 \\
(89.8)\end{array}$ & $\begin{array}{l}37,088 \\
(90.2)\end{array}$ & $\begin{array}{l}44,174 \\
(92.2)\end{array}$ & $\begin{array}{l}77,579 \\
(88.6)\end{array}$ & $\begin{array}{l}1,539 \\
(87.8)\end{array}$ & $\begin{array}{l}4,814 \\
(84.9)\end{array}$ & $<0.0001$ & $<0.0001$ \\
\hline Sex (vaginal or anal) with a male & $\begin{array}{l}164,486 \\
(89.4)\end{array}$ & $\begin{array}{l}36,982 \\
(89.9)\end{array}$ & $\begin{array}{l}43,848 \\
(91.5)\end{array}$ & $\begin{array}{l}77,332 \\
(88.3)\end{array}$ & $\begin{array}{l}1,532 \\
(87.4)\end{array}$ & $\begin{array}{l}4,792 \\
(84.5)\end{array}$ & $<0.0001$ & $<0.0001$ \\
\hline $\begin{array}{l}\text { Sex for drugs/money/other items } \\
\text { (anal, vaginal or oral) }\end{array}$ & $\begin{array}{l}6,579 \\
(3.6)\end{array}$ & $\begin{array}{l}745 \\
(1.8)\end{array}$ & $\begin{array}{l}3,775 \\
(7.9)\end{array}$ & $\begin{array}{l}1,883 \\
(2.2)\end{array}$ & $\begin{array}{l}38 \\
(2.2)\end{array}$ & $\begin{array}{l}138 \\
(2.4)\end{array}$ & $<0.0001$ & $<0.0001$ \\
\hline STD diagnosis & $\begin{array}{l}13,616 \\
(7.4)\end{array}$ & $\begin{array}{l}1,971 \\
(4.8)\end{array}$ & $\begin{array}{l}3,994 \\
(8.3)\end{array}$ & $\begin{array}{l}7,066 \\
(8.1)\end{array}$ & $\begin{array}{l}108 \\
(6.2)\end{array}$ & $\begin{array}{l}477 \\
(8.4)\end{array}$ & $<0.0001$ & $<0.0001$ \\
\hline Injection drug use & $\begin{array}{l}5,789 \\
(3.1)\end{array}$ & $\begin{array}{l}566 \\
(1.4)\end{array}$ & $\begin{array}{l}4,751 \\
(9.9)\end{array}$ & $\begin{array}{l}305 \\
(0.4)\end{array}$ & $\begin{array}{l}44 \\
(2.5)\end{array}$ & $\begin{array}{l}123 \\
(2.2)\end{array}$ & $<0.0001$ & $<0.0001$ \\
\hline Any partner risk & $\begin{array}{l}9,130 \\
(5.0)\end{array}$ & $\begin{array}{l}1,276 \\
(3.1)\end{array}$ & $\begin{array}{l}5,881 \\
(12.3)\end{array}$ & $\begin{array}{l}1,691 \\
(1.9)\end{array}$ & $\begin{array}{l}77 \\
(4.4)\end{array}$ & $\begin{array}{l}205 \\
(3.6)\end{array}$ & $<0.0001$ & $<0.0001$ \\
\hline $\begin{array}{l}\text { Sex (vaginal or anal) with HIV- } \\
\text { positive person }\end{array}$ & $\begin{array}{l}2,101 \\
(1.1)\end{array}$ & $\begin{array}{l}434 \\
(1.1)\end{array}$ & $\begin{array}{l}707 \\
(1.5)\end{array}$ & $\begin{array}{l}899 \\
(1.0)\end{array}$ & $\begin{array}{l}14 \\
(0.8)\end{array}$ & $\begin{array}{l}47 \\
(0.8)\end{array}$ & $<0.0001$ & 0.6330 \\
\hline $\begin{array}{l}\text { Sex (vaginal or anal) with an } \\
\text { IDU }\end{array}$ & $\begin{array}{l}5,795 \\
(3.1)\end{array}$ & $\begin{array}{l}635 \\
(1.5)\end{array}$ & $\begin{array}{l}4,669 \\
(9.7)\end{array}$ & $\begin{array}{l}311 \\
(0.4)\end{array}$ & $\begin{array}{l}53 \\
(3.0)\end{array}$ & $\begin{array}{l}127 \\
(2.2)\end{array}$ & $<0.0001$ & $<0.0001$ \\
\hline $\begin{array}{l}\text { Sex (vaginal or anal) with a } \\
\text { MSM }\end{array}$ & $\begin{array}{l}2,023 \\
(1.1)\end{array}$ & $\begin{array}{l}323 \\
(0.8)\end{array}$ & $\begin{array}{l}1,037 \\
(2.2)\end{array}$ & $\begin{array}{l}595 \\
(0.7)\end{array}$ & $\begin{array}{l}18 \\
(1.0)\end{array}$ & $\begin{array}{l}50 \\
(0.9)\end{array}$ & $<0.0001$ & 0.0350 \\
\hline Any personal or partner risk & $\begin{array}{l}165,420 \\
(89.9)\end{array}$ & $\begin{array}{l}37,125 \\
(90.3)\end{array}$ & $\begin{array}{l}44,243 \\
(92.3)\end{array}$ & $\begin{array}{l}77,693 \\
(88.7)\end{array}$ & $\begin{array}{l}1,541 \\
(87.9)\end{array}$ & $\begin{array}{l}4,818 \\
(84.9)\end{array}$ & $<0.0001$ & $<0.0001$ \\
\hline Previous HIV testing & & & & & & & $<0.0001$ & $<0.0001$ \\
\hline Yes & $\begin{array}{l}139,854 \\
(76.0)\end{array}$ & $\begin{array}{l}28,536 \\
(69.4)\end{array}$ & $\begin{array}{l}34,703 \\
(72.4)\end{array}$ & $\begin{array}{l}71,689 \\
(81.9)\end{array}$ & $\begin{array}{l}1,132 \\
(64.6)\end{array}$ & $\begin{array}{l}3,794 \\
(66.9)\end{array}$ & & \\
\hline No & $\begin{array}{l}37,323 \\
(20.3)\end{array}$ & $\begin{array}{l}11,019 \\
(26.8)\end{array}$ & $\begin{array}{l}10,940 \\
(22.8)\end{array}$ & $\begin{array}{l}13,621 \\
(15.6)\end{array}$ & $\begin{array}{l}540 \\
(30.8)\end{array}$ & $\begin{array}{l}1,203 \\
(21.2)\end{array}$ & & \\
\hline
\end{tabular}




\begin{tabular}{|c|c|c|c|c|c|c|}
\hline Don't Know/refused & $\begin{array}{l}6,860 \\
(3.7)\end{array}$ & $\begin{array}{l}1,562 \\
(3.8)\end{array}$ & $\begin{array}{l}2,283 \\
(4.8)\end{array}$ & $\begin{array}{l}2,259 \\
(2.6)\end{array}$ & $\begin{array}{l}81 \\
(4.6)\end{array}$ & $\begin{array}{l}675 \\
(11.9)\end{array}$ \\
\hline
\end{tabular}

STD = sexually transmitted disease; HIV = human immunodeficiency virus; IDU = injection drug user; MSM = man that has sex with men ${ }^{\mathrm{a} C h i}$-squared statistics were used to compare the variables (alpha $\left.=0.05\right)$ 
Table 3. Adjusted odds ratio estimates for partner risk and personal risk among women not pregnant and tested for HIV in Florida 2012, by race/ethnicity, foreign-born vs. US-born, and country of birth.

\begin{tabular}{|c|c|c|}
\hline & $\begin{array}{l}\text { Partner Risk OR }{ }^{\mathrm{a}} \\
(95 \% \mathrm{CI})\end{array}$ & $\begin{array}{l}\text { Personal Risk OR } \\
(95 \% \mathrm{CI})\end{array}$ \\
\hline \multicolumn{3}{|c|}{ Model 1 Independent variable race/ethnicity } \\
\hline Non-Hispanic White & Referent & Referent \\
\hline Latina & $0.38(0.35,0.41)$ & $0.85(0.80,0.89)$ \\
\hline Non-Hispanic Black & $0.18(0.17,0.20)$ & $0.71(0.68,0.75)$ \\
\hline Other & $0.41(0.32,0.52)$ & $0.69(0.59,0.81)$ \\
\hline Missing & $0.43(0.37,0.50)$ & $0.56(0.51,0.61)$ \\
\hline \multicolumn{3}{|c|}{ Model 2 Independent variable US vs. foreign birth } \\
\hline US-born & Referent & Referent \\
\hline Foreign-born & $0.46(0.40,0.54)$ & $0.98(0.89,1.08)$ \\
\hline missing & $0.77(0.62,0.95)$ & $1.00(0.86,1.16)$ \\
\hline \multicolumn{3}{|c|}{ Model 3 Independent variable country of birth } \\
\hline US & Referent & Referent \\
\hline Mexico & $0.21(0.15,0.29)$ & $1.31(1.13,1.52)$ \\
\hline Cuba & $0.50(0.38,0.66)$ & $0.98(0.85,1.14)$ \\
\hline Guatemala & $0.07(0.03,0.23)$ & $0.92(0.73,1.15)$ \\
\hline Honduras & $0.37(0.24,0.56)$ & $1.07(0.88,1.31)$ \\
\hline Colombia & $0.39(0.28,0.55)$ & $0.90(0.77,1.06)$ \\
\hline Puerto Rico & $0.99(0.78,1.25)$ & $0.85(0.72,1.01)$ \\
\hline Nicaragua & $0.37(0.22,0.62)$ & $0.87(0.69,1.09)$ \\
\hline El Salvador & $0.35(0.17,0.69)$ & $1.23(0.89,1.68)$ \\
\hline Dominican Republic & $0.48(0.31,0.75)$ & $0.80(0.65,0.99)$ \\
\hline Peru & $0.38(0.23,0.65)$ & $0.99(0.78,1.26)$ \\
\hline Venezuela & $0.29(0.15,0.55)$ & $0.80(0.63,1.02)$ \\
\hline Brazil & $0.71(0.40,1.26)$ & $1.05(0.71,1.53)$ \\
\hline
\end{tabular}




\begin{tabular}{lll}
\hline Other South America & $0.52(0.34,0.79)$ & $1.08(0.87,1.36)$ \\
Other Central America & $0.72(0.40,1.28)$ & $1.26(0.86,1.86)$ \\
Other non-Latino countries & $0.52(0.26,1.05)$ & $0.95(0.63,1.43)$ \\
Missing & $0.71(0.58,0.88)$ & $0.99(0.86,1.14)$ \\
\hline
\end{tabular}

${ }^{\text {a }}$ Odds ratios adjusted for age 
Table 4. HIV risk behaviors, previous HIV testing and demographics by US-Born and Foreign-Born Latinas who were not pregnant at time of testing

\begin{tabular}{|c|c|c|c|c|c|}
\hline Country of Birth & $\begin{array}{l}\text { US-born } \\
\mathrm{n}(\%)\end{array}$ & $\begin{array}{l}\text { Foreign-born } \\
\mathrm{n}(\%)\end{array}$ & $\begin{array}{l}\text { Missing } \\
\mathrm{n}(\%)\end{array}$ & $\begin{array}{l}\text { US-born } \\
\text { vs. } \\
\text { Foreign- } \\
\text { born } \\
\text { p-value }{ }^{\text {a }}\end{array}$ & $\begin{array}{l}\text { Foreign- } \\
\text { born vs. } \\
\text { Missing } \\
\text { p-value }\end{array}$ \\
\hline Total & $\mathrm{n}=9333$ & $\mathrm{n}=25363$ & $n=6421$ & & \\
\hline Mean Age (years) & 29.0 & 35.0 & 26.7 & & \\
\hline Age Group (n) & & & & $<0.0001$ & $<0.0001$ \\
\hline $13-19$ & $1614(17.3)$ & $1353(5.3)$ & $1412(22.0)$ & & \\
\hline $20-29$ & $4671(50.1)$ & $8241(32.5)$ & $3130(48.8)$ & & \\
\hline $30-39$ & $1690(18.1)$ & $7876(31.1)$ & $1182(18.4)$ & & \\
\hline $40-49$ & $930(10.0)$ & $4628(18.3)$ & $480(7.5)$ & & \\
\hline 50 and over & $428(4.6)$ & $3265(12.9)$ & $217(3.4)$ & & \\
\hline Any personal risk (n) & $8331(89.3)$ & $22799(89.9)$ & $5958(92.8)$ & 0.0882 & $<0.0001$ \\
\hline $\begin{array}{l}\text { Sex (vaginal or anal) with a } \\
\text { male }\end{array}$ & $8273(88.6)$ & $22778(89.8)$ & $5931(92.4)$ & 0.0017 & $<00001$ \\
\hline $\begin{array}{l}\text { Sex for drugs/money/other } \\
\text { items (anal, vaginal or oral) }\end{array}$ & $407(4.4)$ & $174(0.7)$ & $164(2.6)$ & $<0.0001$ & $<0.0001$ \\
\hline STD diagnosis & $725(7.8)$ & $758(3.0)$ & $488(7.6)$ & $<0.0001$ & $<0.0001$ \\
\hline Injection drug use & $353(3.8)$ & $105(0.4)$ & $108(1.7)$ & $<0.0001$ & $<0.0001$ \\
\hline Any partner risk (n) & $618(6.6)$ & $442(1.7)$ & $216(3.4)$ & $<0.0001$ & $<0.0001$ \\
\hline $\begin{array}{l}\text { Sex (vaginal or anal) with } \\
\text { HIV-positive person }\end{array}$ & $155(1.7)$ & $223(0.9)$ & $56(0.9)$ & $<0.0001$ & 0.9566 \\
\hline $\begin{array}{l}\text { Sex (vaginal or anal) with an } \\
\text { IDU }\end{array}$ & $369(4.0)$ & $142(0.6)$ & 124 (1.9) & $<0.0001$ & $<0.0001$ \\
\hline $\begin{array}{l}\text { Sex (vaginal or anal) with a } \\
\text { MSM }\end{array}$ & $152(1.6)$ & $112(0.4)$ & $59(0.9)$ & $<0.0001$ & $<0.0001$ \\
\hline $\begin{array}{l}\text { Any personal or partner risk } \\
\text { (n) }\end{array}$ & $8355(89.5)$ & $22808(89.9)$ & $5962(92.9)$ & 0.2684 & $<0.0001$ \\
\hline Previous HIV testing (n) & & & & $<0.0001$ & $<0.0001$ \\
\hline Yes & $6526(70.3)$ & $17484(68.9)$ & $4526(70.5)$ & & \\
\hline No & $2583(27.7)$ & $6875(27.1)$ & $1561(24.3)$ & & \\
\hline Don't Know/Refused & $296(2.7)$ & $932(4.0)$ & $334(5.2)$ & & \\
\hline
\end{tabular}

${ }^{\mathrm{a}}$ Chi squared statistics were used to compare the variables $($ alpha $=0.05)$ 
STD = sexually transmitted disease, HIV = human immunodeficiency virus, IDU = injection drug user, $\mathrm{MSM}=$ man that has sex with men 
Table 5: HIV risk behaviors, previous HIV testing and demographics by Country of Birth among Latina women who are not pregnant at the time of testing

\begin{tabular}{|c|c|c|c|c|c|c|c|c|c|}
\hline Latina Country of Birth & $\begin{array}{l}U^{a}{ }^{a} \\
\text { n }(\%)\end{array}$ & $\begin{array}{l}\mathrm{Me}^{\mathrm{b}} \\
\mathrm{n}(\%)\end{array}$ & $\begin{array}{l}\mathrm{Cu}^{\mathrm{c}} \\
\mathbf{n}(\%)\end{array}$ & $\begin{array}{l}\mathrm{Co}^{\mathrm{d}} \\
\mathrm{n}(\%)\end{array}$ & $\begin{array}{l}\mathbf{G u}^{\mathrm{e}} \\
\mathbf{n}(\%)\end{array}$ & $\begin{array}{l}\mathbf{H o}^{\mathrm{f}} \\
\mathrm{n}(\%)\end{array}$ & $\begin{array}{l}P^{g} \\
\text { n }(\%)\end{array}$ & $\begin{array}{l}\mathrm{Ni}^{\mathrm{h}} \\
\mathrm{n}(\%)\end{array}$ & $\begin{array}{l}\text { ES }^{\mathrm{i}} \\
\mathrm{n}(\%)\end{array}$ \\
\hline Total (n) & 9,333 & 6,540 & 3,944 & 2,241 & 1,826 & 1,916 & 1,794 & 1,052 & 898 \\
\hline Mean Age (years) & 27.9 & 32.5 & 36.9 & 39.5 & 31.4 & 34.6 & 34.7 & 37.8 & 32.8 \\
\hline \multicolumn{10}{|l|}{ Age Group } \\
\hline $13-19$ & $\begin{array}{l}1,614 \\
(17.3)\end{array}$ & $\begin{array}{l}322 \\
(4.9)\end{array}$ & $\begin{array}{l}273 \\
(6.9)\end{array}$ & $\begin{array}{l}117 \\
(5.2)\end{array}$ & $\begin{array}{l}46 \\
(2.5)\end{array}$ & $\begin{array}{l}69 \\
(3.6)\end{array}$ & $\begin{array}{l}160 \\
(8.9)\end{array}$ & $\begin{array}{l}25 \\
(2.3)\end{array}$ & $\begin{array}{l}35 \\
(3.9)\end{array}$ \\
\hline $20-29$ & $\begin{array}{l}4,671 \\
(50.1)\end{array}$ & $\begin{array}{l}2,346 \\
(35.9)\end{array}$ & $\begin{array}{l}1,188 \\
(30.1)\end{array}$ & $\begin{array}{l}527 \\
(23.5)\end{array}$ & $\begin{array}{l}839 \\
(46.0)\end{array}$ & $\begin{array}{l}655 \\
(34.2)\end{array}$ & $\begin{array}{l}565 \\
(31.5)\end{array}$ & $\begin{array}{l}269 \\
(25.6)\end{array}$ & $\begin{array}{l}333 \\
(37.1)\end{array}$ \\
\hline $30-39$ & $\begin{array}{l}1,690 \\
(18.1)\end{array}$ & $\begin{array}{l}2,569 \\
(39.3)\end{array}$ & $\begin{array}{l}818 \\
(20.7)\end{array}$ & $\begin{array}{l}484 \\
(21.6)\end{array}$ & $\begin{array}{l}684 \\
(37.5)\end{array}$ & $\begin{array}{l}673 \\
(35.1)\end{array}$ & $\begin{array}{l}471 \\
(26.3)\end{array}$ & $\begin{array}{l}328 \\
(31.2)\end{array}$ & $\begin{array}{l}348 \\
(38.8)\end{array}$ \\
\hline $40-49$ & $\begin{array}{l}930 \\
(10.0)\end{array}$ & $\begin{array}{l}994 \\
(15.2)\end{array}$ & $\begin{array}{l}893 \\
(22.6)\end{array}$ & $\begin{array}{l}523 \\
(23.3)\end{array}$ & $\begin{array}{l}184 \\
(10.1)\end{array}$ & $\begin{array}{l}288 \\
(15.0)\end{array}$ & $\begin{array}{l}366 \\
(20.4)\end{array}$ & $\begin{array}{l}240 \\
(22.8)\end{array}$ & $\begin{array}{l}126 \\
(14.0)\end{array}$ \\
\hline 50 and over & $\begin{array}{l}428 \\
(4.6)\end{array}$ & $\begin{array}{l}309 \\
(4.7)\end{array}$ & $\begin{array}{l}772 \\
(19.6)\end{array}$ & $\begin{array}{l}603 \\
(26.2)\end{array}$ & $\begin{array}{l}73 \\
(4.0)\end{array}$ & $\begin{array}{l}231 \\
(12.1)\end{array}$ & $\begin{array}{l}232 \\
(12.9)\end{array}$ & $\begin{array}{l}190 \\
(18.1)\end{array}$ & $\begin{array}{l}56 \\
(6.2)\end{array}$ \\
\hline Any personal risk & $\begin{array}{l}8,331 \\
(89.3)\end{array}$ & $\begin{array}{l}6,118 \\
(93.6)\end{array}$ & $\begin{array}{l}3,471 \\
(88.0)\end{array}$ & $\begin{array}{l}1,907 \\
(85.1)\end{array}$ & $\begin{array}{l}1,699 \\
(93.0)\end{array}$ & $\begin{array}{l}1,755 \\
(91.6)\end{array}$ & $\begin{array}{l}1,559 \\
(86.9)\end{array}$ & $\begin{array}{l}930 \\
(88.4)\end{array}$ & $\begin{array}{l}841 \\
(93.7)\end{array}$ \\
\hline $\begin{array}{l}\text { Sex (vaginal or anal) with a } \\
\text { male }\end{array}$ & $\begin{array}{l}8,273 \\
(88.6)\end{array}$ & $\begin{array}{l}6,115 \\
(93.5)\end{array}$ & $\begin{array}{l}3,467 \\
(87.9)\end{array}$ & $\begin{array}{l}1,906 \\
(85.1)\end{array}$ & $\begin{array}{l}1,698 \\
(93.0)\end{array}$ & $\begin{array}{l}1,753 \\
(91.5)\end{array}$ & $\begin{array}{l}1,558 \\
(86.9)\end{array}$ & $\begin{array}{l}929 \\
(88.3)\end{array}$ & $\begin{array}{l}840 \\
(93.5)\end{array}$ \\
\hline $\begin{array}{l}\text { Sex for drugs, money, or other } \\
\text { items (anal, vaginal, or oral) }\end{array}$ & $\begin{array}{l}407 \\
(4.4)\end{array}$ & $\begin{array}{l}11 \\
(0.2)\end{array}$ & $\begin{array}{l}46 \\
(1.2)\end{array}$ & $\begin{array}{l}9 \\
(0.4)\end{array}$ & $\begin{array}{l}9 \\
(0.5)\end{array}$ & $\begin{array}{l}11 \\
(0.6)\end{array}$ & $\begin{array}{l}39 \\
(2.2)\end{array}$ & $\begin{array}{l}5 \\
(0.5)\end{array}$ & $\begin{array}{l}2 \\
(0.2)\end{array}$ \\
\hline STD diagnosis & $\begin{array}{l}725 \\
(7.8)\end{array}$ & $\begin{array}{l}141 \\
(2.2)\end{array}$ & $\begin{array}{l}122 \\
(3.1)\end{array}$ & $\begin{array}{l}55 \\
(2.5)\end{array}$ & $\begin{array}{l}40 \\
(2.2)\end{array}$ & $\begin{array}{l}58 \\
(3.0)\end{array}$ & $\begin{array}{l}75 \\
(4.2)\end{array}$ & $\begin{array}{l}41 \\
(3.9)\end{array}$ & $\begin{array}{l}20 \\
(2.2)\end{array}$ \\
\hline Injection drug use & $\begin{array}{l}353 \\
(3.8)\end{array}$ & $\begin{array}{l}6 \\
(0.1)\end{array}$ & $\begin{array}{l}23 \\
(0.6)\end{array}$ & $\begin{array}{l}7 \\
(0.3)\end{array}$ & $\begin{array}{l}2 \\
(0.1)\end{array}$ & $\begin{array}{l}3 \\
(0.2)\end{array}$ & $\begin{array}{l}33 \\
(1.8)\end{array}$ & $\begin{array}{l}3 \\
(0.3)\end{array}$ & $\begin{array}{l}2 \\
(0.2)\end{array}$ \\
\hline Any partner risk & $\begin{array}{l}618 \\
(6.6)\end{array}$ & $\begin{array}{l}50 \\
(0.8)\end{array}$ & $\begin{array}{l}78 \\
(2.0)\end{array}$ & $\begin{array}{l}40 \\
(1.8)\end{array}$ & $\begin{array}{l}4 \\
(0.2)\end{array}$ & $\begin{array}{l}25 \\
(1.3)\end{array}$ & $\begin{array}{l}105 \\
(5.9)\end{array}$ & $\begin{array}{l}16 \\
(1.5)\end{array}$ & $\begin{array}{l}9 \\
(1.0)\end{array}$ \\
\hline
\end{tabular}




\begin{tabular}{|c|c|c|c|c|c|c|c|c|c|}
\hline $\begin{array}{l}\text { Sex (vaginal or anal) with } \\
\text { HIV-positive person }\end{array}$ & $\begin{array}{l}155 \\
(1.7)\end{array}$ & $\begin{array}{l}20 \\
(0.3)\end{array}$ & $\begin{array}{l}42 \\
(1.1)\end{array}$ & $\begin{array}{l}21 \\
(0.9)\end{array}$ & $\begin{array}{l}3 \\
(0.2)\end{array}$ & $\begin{array}{l}20 \\
(1.0)\end{array}$ & $\begin{array}{l}47 \\
(2.6)\end{array}$ & $\begin{array}{l}11 \\
(1.1)\end{array}$ & $\begin{array}{l}5 \\
(0.6)\end{array}$ \\
\hline $\begin{array}{l}\text { Sex (vaginal or anal) with an } \\
\text { IDU }\end{array}$ & $\begin{array}{l}369 \\
(4.0)\end{array}$ & $\begin{array}{l}12 \\
(0.2)\end{array}$ & $\begin{array}{l}20 \\
(0.5)\end{array}$ & 9 & $\begin{array}{l}0 \\
(0.0)\end{array}$ & $\begin{array}{l}4 \\
(0.2)\end{array}$ & $\begin{array}{l}58 \\
(3.2)\end{array}$ & $\begin{array}{l}3 \\
(0.3)\end{array}$ & $\begin{array}{l}4 \\
(0.5)\end{array}$ \\
\hline $\begin{array}{l}\text { Sex (vaginal or anal) with a } \\
\text { MSM }\end{array}$ & $\begin{array}{l}152 \\
(1.6)\end{array}$ & $\begin{array}{l}19 \\
(0.3)\end{array}$ & $\begin{array}{l}21 \\
(0.5)\end{array}$ & $\begin{array}{l}10 \\
(0.5)\end{array}$ & $\begin{array}{l}1 \\
(0.1)\end{array}$ & $\begin{array}{l}2 \\
(0.1)\end{array}$ & $\begin{array}{l}16 \\
(0.9)\end{array}$ & $\begin{array}{l}2 \\
(0.2)\end{array}$ & $\begin{array}{l}2 \\
(0.2)\end{array}$ \\
\hline $\begin{array}{l}\text { Any personal or partner } \\
\text { risk }\end{array}$ & $\begin{array}{l}8,355 \\
(89.5)\end{array}$ & $\begin{array}{l}6,118 \\
(93.6)\end{array}$ & $\begin{array}{l}3,473 \\
(88.1)\end{array}$ & $\begin{array}{l}1,910 \\
(85.2)\end{array}$ & $\begin{array}{l}1,699 \\
(93.0)\end{array}$ & $\begin{array}{l}1,755 \\
(91.6)\end{array}$ & $\begin{array}{l}1,560 \\
(87.0)\end{array}$ & $\begin{array}{l}930 \\
(88.4)\end{array}$ & $\begin{array}{l}841 \\
(93.7)\end{array}$ \\
\hline \multicolumn{10}{|l|}{ Previous HIV testing } \\
\hline Yes & $\begin{array}{l}6,526 \\
(69.9)\end{array}$ & $\begin{array}{l}4,785 \\
(73.2)\end{array}$ & $\begin{array}{l}2,400 \\
(60.9)\end{array}$ & $\begin{array}{l}1,447 \\
(64.6)\end{array}$ & $\begin{array}{l}1,199 \\
(65.7)\end{array}$ & $\begin{array}{l}1,375 \\
(71.8)\end{array}$ & $\begin{array}{l}1,294 \\
(72.1)\end{array}$ & $\begin{array}{l}705 \\
(67.0)\end{array}$ & $\begin{array}{l}660 \\
(73.5)\end{array}$ \\
\hline No & $\begin{array}{l}2,583 \\
(27.7)\end{array}$ & $\begin{array}{l}1,549 \\
(23.7)\end{array}$ & $\begin{array}{l}1,350 \\
(34.2)\end{array}$ & $\begin{array}{l}712 \\
(31.8)\end{array}$ & $\begin{array}{l}538 \\
(29.5)\end{array}$ & $\begin{array}{l}467 \\
(24.4)\end{array}$ & $\begin{array}{l}428 \\
(23.9)\end{array}$ & $\begin{array}{l}300 \\
(28.5)\end{array}$ & $\begin{array}{l}198 \\
(22.1)\end{array}$ \\
\hline Don’t Know/Refused & $\begin{array}{l}224 \\
(2.4)\end{array}$ & $\begin{array}{l}206 \\
(3.2)\end{array}$ & $\begin{array}{l}194 \\
(4.9)\end{array}$ & $\begin{array}{l}82 \\
(3.7)\end{array}$ & $\begin{array}{l}89 \\
(4.9)\end{array}$ & $\begin{array}{l}74 \\
(3.9)\end{array}$ & $\begin{array}{l}72 \\
(4.0)\end{array}$ & $\begin{array}{l}47 \\
(4.5)\end{array}$ & $\begin{array}{l}40 \\
(4.5)\end{array}$ \\
\hline Latina Country of Birth & $\begin{array}{l}\mathbf{D R}^{\mathbf{j}} \\
\mathbf{n}(\%)\end{array}$ & $\begin{array}{l}\mathbf{P e}^{\mathrm{k}} \\
\mathbf{n}(\%)\end{array}$ & $\begin{array}{l}V^{l} \\
n(\%)\end{array}$ & $\begin{array}{l}\text { Brazil } \\
\text { n }(\%)\end{array}$ & $\begin{array}{l}\mathrm{OSA}^{\mathrm{m}} \\
\mathrm{n}(\%)\end{array}$ & $\begin{array}{l}\mathrm{OCA}^{\mathrm{n}} \\
\mathrm{n}(\%)\end{array}$ & $\begin{array}{l}\text { Other }^{0} \\
\text { n }(\%)\end{array}$ & $\begin{array}{l}\text { Missing }^{\mathbf{p}} \\
\mathbf{n}(\%)\end{array}$ & $p$-value \\
\hline Total (n) & 898 & 1,075 & 887 & 799 & 394 & 1,104 & 367 & 291 & 6,656 \\
\hline Mean Age (years) & 32.8 & 35.8 & 36.8 & 35.9 & 34.8 & 36.8 & 36.2 & 32.9 & 26.9 \\
\hline \multicolumn{10}{|l|}{ Age Group } \\
\hline $13-19$ & $\begin{array}{l}35 \\
(3.9)\end{array}$ & $\begin{array}{l}61 \\
(5.7)\end{array}$ & $\begin{array}{l}50 \\
(5.6)\end{array}$ & $\begin{array}{l}43 \\
(5.4)\end{array}$ & $\begin{array}{l}17 \\
(4.3)\end{array}$ & $\begin{array}{l}76 \\
(6.9)\end{array}$ & $\begin{array}{l}14 \\
(3.8)\end{array}$ & $\begin{array}{l}25 \\
(8.6)\end{array}$ & $\begin{array}{l}1,432 \\
(21.5)\end{array}$ \\
\hline $20-29$ & $\begin{array}{l}333 \\
(37.1)\end{array}$ & $\begin{array}{l}357 \\
(33.2)\end{array}$ & $\begin{array}{l}243 \\
(27.4)\end{array}$ & $\begin{array}{l}238 \\
(29.8)\end{array}$ & $\begin{array}{l}124 \\
(31.5)\end{array}$ & $\begin{array}{l}253 \\
(22.9)\end{array}$ & $\begin{array}{l}109 \\
(29.7)\end{array}$ & $\begin{array}{l}108 \\
(37.1)\end{array}$ & $\begin{array}{l}3,217 \\
(48.3)\end{array}$ \\
\hline $30-39$ & $\begin{array}{l}348 \\
(38.8)\end{array}$ & $\begin{array}{l}262 \\
(24.4)\end{array}$ & $\begin{array}{l}251 \\
(28.3)\end{array}$ & $\begin{array}{l}236 \\
(29.5)\end{array}$ & $\begin{array}{l}141 \\
(35.8)\end{array}$ & $\begin{array}{l}355 \\
(32.2)\end{array}$ & $\begin{array}{l}111 \\
(30.3)\end{array}$ & $\begin{array}{l}78 \\
(26.8)\end{array}$ & $\begin{array}{l}1,249 \\
(18.8)\end{array}$ \\
\hline $40-49$ & $\begin{array}{l}126 \\
(14.0)\end{array}$ & $\begin{array}{l}200 \\
(18.6)\end{array}$ & $\begin{array}{l}189 \\
(21.3)\end{array}$ & $\begin{array}{l}158 \\
(19.8)\end{array}$ & $\begin{array}{l}69 \\
(17.5)\end{array}$ & $\begin{array}{l}239 \\
(21.7)\end{array}$ & $\begin{array}{l}72 \\
(19.6)\end{array}$ & $\begin{array}{l}50 \\
(17.2)\end{array}$ & $\begin{array}{l}517 \\
(7.8)\end{array}$ \\
\hline 50 and over & $\begin{array}{l}56 \\
(6.2)\end{array}$ & $\begin{array}{l}195 \\
(18.1)\end{array}$ & $\begin{array}{l}154 \\
(17.4)\end{array}$ & $\begin{array}{l}124 \\
(15.5)\end{array}$ & $\begin{array}{l}43 \\
(10.9)\end{array}$ & $\begin{array}{l}181 \\
(16.4)\end{array}$ & $\begin{array}{l}61 \\
(16.6)\end{array}$ & $\begin{array}{l}30 \\
(10.3)\end{array}$ & $\begin{array}{l}241 \\
(3.6)\end{array}$ \\
\hline
\end{tabular}




\begin{tabular}{|c|c|c|c|c|c|c|c|c|c|}
\hline Any personal risk & $\begin{array}{l}841 \\
(93.7)\end{array}$ & $\begin{array}{l}930 \\
(88.4)\end{array}$ & $\begin{array}{l}783 \\
(88.3)\end{array}$ & $\begin{array}{l}689 \\
(86.2)\end{array}$ & $\begin{array}{l}359 \\
(91.1)\end{array}$ & $\begin{array}{l}981 \\
(88.9)\end{array}$ & $\begin{array}{l}333 \\
(90.7)\end{array}$ & $\begin{array}{l}259 \\
(89.0)\end{array}$ & $\begin{array}{l}6,143 \\
(92.3)\end{array}$ \\
\hline $\begin{array}{l}\text { Sex (vaginal or anal) with a } \\
\text { male }\end{array}$ & $\begin{array}{l}840 \\
(93.5)\end{array}$ & $\begin{array}{l}930 \\
(86.5)\end{array}$ & $\begin{array}{l}782 \\
(88.2)\end{array}$ & $\begin{array}{l}688 \\
(86.1)\end{array}$ & $\begin{array}{l}358 \\
(90.9)\end{array}$ & $\begin{array}{l}978 \\
(88.6)\end{array}$ & $\begin{array}{l}333 \\
(90.7)\end{array}$ & $\begin{array}{l}259 \\
(89.0)\end{array}$ & $\begin{array}{l}6,115 \\
(91.9)\end{array}$ \\
\hline $\begin{array}{l}\text { Sex for drugs, money, or other } \\
\text { items (anal, vaginal, or oral) }\end{array}$ & $\begin{array}{l}2 \\
(0.2)\end{array}$ & $\begin{array}{l}5 \\
(0.5)\end{array}$ & $\begin{array}{l}8 \\
(0.9)\end{array}$ & $\begin{array}{l}9 \\
(1.1)\end{array}$ & $\begin{array}{l}3 \\
(0.8)\end{array}$ & $\begin{array}{l}10 \\
(0.9)\end{array}$ & $\begin{array}{l}4 \\
(1.1)\end{array}$ & $1(0.3)$ & $\begin{array}{l}166 \\
(2.5)\end{array}$ \\
\hline STD diagnosis & $\begin{array}{l}20 \\
(2.2)\end{array}$ & $\begin{array}{l}35 \\
(3.3)\end{array}$ & $\begin{array}{l}38 \\
(4.3)\end{array}$ & $\begin{array}{l}32 \\
(4.0)\end{array}$ & $\begin{array}{l}17 \\
(4.3)\end{array}$ & $\begin{array}{l}39 \\
(3.5)\end{array}$ & $\begin{array}{l}19 \\
(5.2)\end{array}$ & $\begin{array}{l}18 \\
(6.2)\end{array}$ & $\begin{array}{l}496 \\
(7.5)\end{array}$ \\
\hline Injection drug use & $\begin{array}{l}2 \\
(0.2)\end{array}$ & $\begin{array}{l}0 \\
(0.0)\end{array}$ & $\begin{array}{l}7 \\
(0.8)\end{array}$ & $\begin{array}{l}3 \\
(0.4)\end{array}$ & $\begin{array}{l}2 \\
(0.5)\end{array}$ & 9 & $\begin{array}{l}1 \\
(0.3)\end{array}$ & $\begin{array}{l}3 \\
(1.0)\end{array}$ & $\begin{array}{l}109 \\
(1.6)\end{array}$ \\
\hline Any partner risk & $\begin{array}{l}9 \\
(1.0)\end{array}$ & $\begin{array}{l}22 \\
(2.1)\end{array}$ & $\begin{array}{l}15 \\
(1.7)\end{array}$ & $\begin{array}{l}10 \\
(1.3)\end{array}$ & $\begin{array}{l}13 \\
(3.3)\end{array}$ & $\begin{array}{l}25 \\
(2.3)\end{array}$ & $\begin{array}{l}13 \\
(3.5)\end{array}$ & $\begin{array}{l}9 \\
(3.1)\end{array}$ & $\begin{array}{l}224 \\
(3.4)\end{array}$ \\
\hline $\begin{array}{l}\text { Sex (vaginal or anal) with } \\
\text { HIV-positive person }\end{array}$ & $\begin{array}{l}5 \\
(0.6)\end{array}$ & $\begin{array}{l}13 \\
(1.2)\end{array}$ & $\begin{array}{l}6 \\
(0.7)\end{array}$ & $\begin{array}{l}6 \\
(0.8)\end{array}$ & $\begin{array}{l}4 \\
(1.0)\end{array}$ & $\begin{array}{l}14 \\
(1.3)\end{array}$ & $\begin{array}{l}6 \\
(1.6)\end{array}$ & $\begin{array}{l}3 \\
(1.0)\end{array}$ & $\begin{array}{l}590 \\
(0.9)\end{array}$ \\
\hline $\begin{array}{l}\text { Sex (vaginal or anal) with an } \\
\text { IDU }\end{array}$ & $\begin{array}{l}4 \\
(0.5)\end{array}$ & $\begin{array}{l}5 \\
(0.5)\end{array}$ & $\begin{array}{l}6 \\
(0.7)\end{array}$ & $\begin{array}{l}1 \\
(0.1)\end{array}$ & $\begin{array}{l}1 \\
(0.3)\end{array}$ & $\begin{array}{l}9 \\
(0.8)\end{array}$ & $\begin{array}{l}3 \\
(0.8)\end{array}$ & $\begin{array}{l}4 \\
(1.4)\end{array}$ & $\begin{array}{l}127 \\
(1.9)\end{array}$ \\
\hline $\begin{array}{l}\text { Sex (vaginal or anal) with a } \\
\text { MSM }\end{array}$ & $\begin{array}{l}2 \\
(0.2)\end{array}$ & $\begin{array}{l}6 \\
(0.6)\end{array}$ & $\begin{array}{l}6 \\
(0.7)\end{array}$ & $\begin{array}{l}3 \\
(0.4)\end{array}$ & $\begin{array}{l}8 \\
(2.0)\end{array}$ & $\begin{array}{l}6 \\
(0.5)\end{array}$ & $\begin{array}{l}6 \\
(1.6)\end{array}$ & $\begin{array}{l}2 \\
(0.7)\end{array}$ & $\begin{array}{l}61 \\
(0.9)\end{array}$ \\
\hline $\begin{array}{l}\text { Any personal or partner } \\
\text { risk }\end{array}$ & $\begin{array}{l}841 \\
(93.7)\end{array}$ & $\begin{array}{l}932 \\
(86.7)\end{array}$ & $\begin{array}{l}783 \\
(88.3)\end{array}$ & $\begin{array}{l}689 \\
(86.2)\end{array}$ & $\begin{array}{l}359 \\
(91.1)\end{array}$ & $\begin{array}{l}981 \\
(88.9)\end{array}$ & $\begin{array}{l}334 \\
(91.0)\end{array}$ & $\begin{array}{l}259 \\
(89.0)\end{array}$ & $\begin{array}{l}6,147 \\
(92.4)\end{array}$ \\
\hline \multicolumn{10}{|l|}{ Previous HIV testing } \\
\hline Yes & $\begin{array}{l}660 \\
(73.5)\end{array}$ & $\begin{array}{l}782 \\
(72.7)\end{array}$ & $\begin{array}{l}603 \\
(68.0)\end{array}$ & $\begin{array}{l}567 \\
(71.0)\end{array}$ & $\begin{array}{l}296 \\
(75.1)\end{array}$ & $\begin{array}{l}736 \\
(66.7)\end{array}$ & $\begin{array}{l}283 \\
(77.1)\end{array}$ & $\begin{array}{l}215 \\
(73.9)\end{array}$ & $\begin{array}{l}4,663 \\
(70.1)\end{array}$ \\
\hline No & $\begin{array}{l}198 \\
(22.1)\end{array}$ & $\begin{array}{l}259 \\
(24.1)\end{array}$ & $\begin{array}{l}252 \\
(28.4)\end{array}$ & $\begin{array}{l}209 \\
(26.2)\end{array}$ & $\begin{array}{l}82 \\
(20.8)\end{array}$ & $\begin{array}{l}322 \\
(29.2)\end{array}$ & $\begin{array}{l}76 \\
(20.7)\end{array}$ & $\begin{array}{l}67 \\
(23.0)\end{array}$ & $\begin{array}{l}1,627 \\
(24.4)\end{array}$ \\
\hline Don’t Know/Refused & $\begin{array}{l}40 \\
(4.5)\end{array}$ & $\begin{array}{l}34 \\
(3.2)\end{array}$ & $\begin{array}{l}32 \\
(3.6)\end{array}$ & $\begin{array}{l}23 \\
(2.9)\end{array}$ & $\begin{array}{l}16 \\
(4.1)\end{array}$ & $\begin{array}{l}46 \\
(4.2)\end{array}$ & $\begin{array}{l}8 \\
(2.2)\end{array}$ & $\begin{array}{l}9 \\
(3.1)\end{array}$ & $\begin{array}{l}366 \\
(5.5)\end{array}$ \\
\hline
\end{tabular}


STD = sexually transmitted disease, HIV = human immunodeficiency virus, IDU = injection drug user, MSM = man that has sex with men ${ }^{a}$ US: United States and territories excluding Puerto Rico

${ }^{\mathrm{b}}$ Me: Mexico

${ }^{\mathrm{c}} \mathrm{Cu}$ : Cuba

${ }^{\mathrm{d}}$ Co: Colombia

e Gu: Guatemala

${ }^{\mathrm{f}}$ Ho: Honduras

g PR: Puerto Rico

${ }^{\text {h }} \mathrm{Ni}$ : Nicaragua

${ }^{\text {i }}$ ES: El Salvador

${ }^{\mathrm{j}}$ DR: Dominican Republic

${ }^{k}$ Pe: Peru

${ }^{1}$ Ve: Venezuela

m OSA: other South America

${ }^{n}$ OCA: other Central America

o Other: other country of birth

${ }^{\mathrm{p}}$ Missing: country of birth not documented 


\section{MANUSCRIPT 2}

(C) Copyright 2017

Taveras, J., Trepka, M., Khan, H., Madhivanan, P., Gollub, E., Devieux, J. (2017). HIV testing behaviors among Latina women testing for HIV in Florida, 2012. Hispanic Health Care International, 15(1), 27-34.

Abstract

Introduction: Latina women in the United States (US) are not only disproportionately affected by human immunodeficiency virus (HIV) infection, but also underutilize HIV prevention services, such as HIV testing. Methods: HIV testing events were examined to describe the HIV testing behaviors and test results among Latinas tested in 2012 at publicly funded sites in Florida, US. Multivariable logistic regression was used to assess the demographic characteristics associated with reports of previous testing and positive HIV test results. Results: Of the 184,037 testing events, 87,569 (45.6\%) were among non-Hispanic Blacks (NHBs), 47,926 (26.0\%) non-Hispanic Whites (NHWs), 41,117 $(22.3 \%)$ Latinas, 5,672 (3.1\%) those with unknown race/ethnicity, and 1,753 (1.0\%) other racial/ethnic groups. Compared to NHW and NHB women, Latinas testing for HIV were older (mean age 32.1, NHW mean age 30.3, NHB mean age 30.0; $p<0.0001$ ). Results indicated that women who reported previous HIV testing had decreased odds of being Latina (adjusted odds ratio [AOR] 0.90; 95\% confidence interval [CI] 0.87, 0.94).

Conclusion: These findings indicate that Latinas are underutilizing HIV testing, and efforts are needed to increase the proportion of Latinas, especially younger Latinas, tested for HIV in Florida. 


\section{KEYWORDS}

Latinas, HIV, HIV testing, HIV screening, High Impact Prevention

\section{Introduction}

The demographics of the HIV epidemic in the US have changed over the years; HIV infection now affects more women and members of ethnic/racial minority populations than in previous years (Institute of Medicine, 2001; CDC, 2016a). Although Latinos make up approximately $17 \%$ of the US population, they make up about $24 \%$ of all new HIV infection diagnoses (United States Census Bureau, 2015; CDC, 2016a). In 2014, the incidence of HIV among Latino men was more than triple the rate among nonHispanic white (NHW) men (37.4 cases per 100,000 vs. 10.8 cases per 100,000), and rates between Latina women and NHW women demonstrates a similar disparity (5.3 cases per 100,000 vs. 1.6 cases per 100,000) (CDC, 2016a). Given these incidence rates, it is particularly important that Latinas be tested for HIV infection.

The CDC recommends that all individuals, aged 13-64 years of age, be screened on an "opt out" basis (consent is inferred unless the patient declines testing) for HIV infection at all health care settings as part of routine medical care. Persons at high-risk for HIV infection should be screened at least once annually (CDC, 2006). Both the CDC's Guide for HIV Testing in Nonclinical Settings and Revised Guidelines for HIV Counseling, Testing, and Referral also emphasize the importance of early knowledge of HIV status and increasing the accessibility and availability of HIV testing services (CDC, 2016b; CDC, 2001). HIV testing is the central step in both the HIV prevention 
continuum and HIV care continuum, which collectively create a framework for monitoring and evaluating HIV program performance (The White House Office of the Press Secretary, 2013; McNairy \& El-Sadr, 2014). HIV testing also creates opportunities to link HIV-positive and HIV-negative people into appropriate care and prevention services. For an HIV-positive person, this means linkage to medical care, appropriate antiretroviral therapy (ARV), and prevention services leading to a suppressed viral load and lower probability of transmitting HIV to sex partners (CDC, 2001; CDC, 2011a; Hall, Walker, Shah \& Belle, 2012; Marks et al., 2005).

Despite the CDC report that HIV testing rates have increased from 2000 to 2010 (CDC, 2013a), the National HIV Behavioral Surveillance data indicate that only $60.7 \%$ of Latinos report ever having tested for HIV compared to $70.2 \%$ among NHWs and $80 \%$ among NHBs (CDC, 2015a). Additionally, Latinos with HIV infection are more likely to be tested late in their HIV infection compared with NHWs (CDC, 2013b; CDC, 2003; Chen, Gallant \& Page, 2012; Sheehan, Trepka \& Dillion, 2014). Early testing can improve HIV-related outcomes along the HIV care continuum including linkage to care, retention in care, and viral load suppression (CDC, 2013b; Gant et al., 2014).

In 2011, Florida had the highest number of publicly funded testing events of all states, accounting for 12\% of all CDC-funded HIV testing events (CDC, 2013c). However, a study of people diagnosed with HIV in Florida between 2007-2011 identified that Latinos were more likely to be diagnosed late with HIV infection (defined as an AIDS diagnosis within 3 months of an HIV diagnosis) than NHWs in urban areas, where the vast majority of HIV infections in Florida occur (Trepka et al., 2014). Furthermore, 
in Florida, the proportion of newly reported HIV infections among Latinas increased from $15 \%$ in 2005 to $17 \%$ in 2014, and Latinas continue to be at higher risk (12 cases per $100,000)$ of acquiring HIV compared with NHW women $(5.4$ cases per 100,000) (Florida Department of Health, 2014; Florida Department of Health, 2013a). The objective of this study was to compare HIV testing behaviors and outcomes between Latina women and women in other racial/ethnic groups tested at publicly funded sites in Florida, a state with a diverse Latina community, in order to determine if HIV testing activities are reaching the populations disproportionately affected by HIV .

\section{Methods}

\section{$\underline{\text { Study design and population }}$}

This cross-sectional study used de-identified data from the Florida HIV Counseling and Testing Database, which included demographic and risk behavior information from all records of women tested for HIV in publicly-funded HIV counseling and testing sites in Florida, totaling 209,954 records. These data were recorded by trained counselors, who collected demographic and risk behavior information from persons voluntarily testing for HIV on the Department of Health 1628 Testing and Counseling Forms. The variables captured included self-reported risk behaviors during the 12 months prior to testing, race, ethnicity, gender, previous HIV testing, and current testing site. This information was sent to the Florida Department of Health Counseling, Testing and Linkage data team, and entered into a database. HIV test results were then additionally included as they became available. Records of women who responded "yes" to current pregnancy $(24,836)$ were excluded from the analysis because these HIV tests may have 
been driven by routine obstetric testing as opposed to testing because of perceived risk of HIV infection. Records from transgender individuals were excluded from the sample because of small numbers (59 Latina, 57 NHW, 120 NHB, 3 belonging to other race/ethnicity, and 3 had unknown race/ethnicity). Records with missing gender information were also excluded (833). The final dataset for the current study included 184,037 publicly-funded HIV testing events for women, 13 years of age and older, in the state of Florida during 2012.

The dataset was of testing events; therefore, it was possible that some women were tested more than once in the given year, resulting in being represented more than once in the dataset. However, because the records were de-identified, it was not possible to exclude records for women that tested more than once in 2012.

\section{$\underline{\text { Classification of variables }}$}

All variables were categorical except for age, which was recoded into age groups: $13-19,20-29,30-39,40-49$ and 50 years and older. Risk factors were categorized as either personal or partner risk. Personal risk was defined as any factor that would place an individual at-risk for HIV based on their own risk behaviors or activities, and partner risk was defined as having vaginal or anal sex with a partner with increased risk of HIV. A woman was considered to have personal risk if she responded "yes" to any of the following within the past 12 months: vaginal/anal sex with a male, anal/vaginal/oral sex for drugs/money/other items, diagnosis of sexually transmitted disease (STD), or injection drug use. "Yes" responses to having vaginal or anal sex with an HIV-positive 
person, an injection drug user (IDU), or a man that has sex with men (MSM) in the past 12 months were considered partner risk (Taveras et al., 2016).

$\underline{\text { Statistical analysis }}$

Descriptive statistics were first performed including age, race/ethnicity, foreignborn versus US-born status, previous HIV testing, and HIV test result. Mean ages were compared using independent sample t-test and analysis of variance. Chi-square tests for categorical variables were performed to identify significant differences in age groups, previous HIV testing and HIV test result by race/ethnicity.

Controlling for age, two multivariable analyses were conducted. The first model included previous HIV testing as the dependent variable. To examine differences in previous HIV testing events among women publicly tested for HIV in Florida, adjusted odds ratio (AOR) and 95\% confidence intervals (CIs) were calculated by analyzing HIV testing: 1) by race/ethnicity and 2) by personal and partner risk. The second model included HIV positivity as the dependent variable which was analyzed three different ways: 1) by race/ethnicity, 2) by personal and partner risk, and 3) by previous testing. In addition to personal and partner risk categories, each risk behavior was analyzed separately (see classification of variables in the above section). Clustering effects of testing site were handled through a random intercept using SAS Proc Glimmix. SAS software, version 9.3 (SAS Institute, Cary, NC 2002) was used to conduct all analyses. The [Blinded for review] and [Blinded for review] Institutional Review Boards (IRB) deemed this study non-human subjects research. 
Results

$\underline{\text { Sample characteristics }}$

Of the 184,037 testing events included in these analyses, $47.6 \%$ were among NHB, 26.0\% were among NHW, 22.3\% were among Latinas, $3.1 \%$ had no recorded race/ethnicity (unknown), and $1.0 \%$ belonged to "other" race/ethnicity (Table 1). Of the testing events, $43.0 \%$ were among US born women, $23.2 \%$ were among foreign-born, and $33.9 \%$ were missing 'country of birth' information. The majority of testing events among Latinas $(61.7 \%)$ and more than one-quarter $(26.1 \%)$ among NHB women were foreign-born. The mean age of women for whom HIV testing events were reported was 30.5 years. Among Latina women, the average age for the reported testing events was higher (mean age 32.1 years) than events among NHW and NHB women (NHW mean age 30.3 years, $p<0.0001$; NHB mean age 30.0 years, $p<0.0001)$. The majority of the testing events $(76.0 \%)$ were among women who had previous HIV testing; $20.3 \%$ were among those with no previous testing; and for $3.7 \%$ it was not known if the woman had previously tested for HIV. Previous HIV testing was less frequently reported among records of Latinas than NHW and NHB women $(69.4 \%$ vs. $72.4 \%, p<0.0001$ and $69.4 \%$ vs. $81.9 \%, p<0.0001$ respectively) (Table 1 ).

$\underline{\text { Previous HIV testing patterns by demographic characteristics and risk behaviors }}$

Testing event records of women with previous HIV testing reported more personal and partner risk than records of women with no previous testing (personal risk $91.3 \%$ vs. $85.0 \%, p<0.0001$; partner risk $5.3 \%$ vs. $3.4 \%, p<0.0001$ ) (Table 2 ). In 
multivariable analysis, after controlling for age, testing events among Latina women demonstrated lower odds and events among NHB women higher odds of previous HIV testing compared with events among NHW women (Latina AOR 0.90, 95\% CI: 0.870.94; NHB AOR 1.85, 95\% CI: 1.79-1.91) (Table 3). Testing events among women who reported any risk (personal or partner) had higher odds of previous HIV testing than testing events among women not reporting risk (personal risk AOR 1.62, 95\% CI: 1.56, 1.68 and partner risk AOR 1.36, 95\% CI: 1.28, 1.44 respectively).

\section{$\underline{\text { HIV test results by demographic characteristics and previous HIV testing }}$}

Among the records of women tested, $0.5 \%$ had a positive HIV test result, and $0.1 \%$ had an indeterminate test result or were missing confirmatory results (Table 1$)$. The highest percentage of records with a positive HIV test result was among NHBs $(0.7 \%)$ followed by NHWs $(0.3 \%)$ and Latinas $(0.3 \%)$. The mean age was 39.2 years for women with records that documented a positive HIV test result and 30.5 years for records that documented an HIV-negative test result. However, the difference was not statistically significant (Table 4). After controlling for age, testing events among NHB women and women with unknown race/ethnicity were more likely to result in HIV-positive outcomes than testing events of NHW women (NHB AOR 2.42, 95\% CI: 1.98, 2.96; unknown race/ethnicity AOR 1.81, 95\% CI: 1.19, 2.75 respectively) (Table 3).

HIV test results by risk behaviors

Personal risk was less likely to be reported in the records that had an HIV-positive result compared to records documenting an HIV-negative test result $(79.4 \%$ versus 
$89.8 \%, p<0.0001$ ) (Table 4). However, in examining specific personal risks, records of women with an HIV-positive test result were significantly more likely to include for drugs/money/other items relative to records of women with an HIV-negative result (8.0\% versus $3.6 \%, p<0.0001)$ or injection drug use $(4.4 \%$ versus $3.1 \%, p=0.0260)$. Partner risk was significantly more likely to be included in records documenting an HIV-positive test result than records documenting a negative HIV test result (15.4\% versus $4.9 \%$, $p<0.0001)$; significant differences were specifically found in records of women engaging in vaginal or anal sex with an HIV-positive person $(11.4 \%$ versus $1.1 \%, p<0.0001)$ (Table 4). In the multivariable analysis, after controlling for age and race/ethnicity, testing events with reports of personal risk were less likely to have an HIV-positive test result than testing events without personal risk (AOR 0.51, 95\% CI: 0.43, 0.61) (Table 3). The testing records that included reports of partner risk had greater odds of documenting a positive test result than records without partner risk (AOR 3.86, 95\% CI: 3.13, 4.76).

\section{Discussion}

Latinas had a similar representation among testing event data (22.3\%) as their proportion of the adult female population in Florida (21.9\%). However, younger Latinas, specifically the 13-19 and 20-29 year age groups, were under-represented among the HIV testing events (Florida Department of Health, n.d.). The average age among Latinas in the HIV testing event records was older than that for other racial/ethnic groups, suggesting that Latinas may be accessing HIV testing services, and consequently, additional prevention services (along the HIV prevention and care continuums) at a later age than other races/ethnicities. Records of Latinas testing for HIV indicated that most 
were foreign-born. The older age of Latinas at the time of testing could be explained by the impact of acculturation onto HIV testing, or it is possible that younger Latinas are not aware of HIV risk, resulting in delays in HIV testing (Kinsler et al., 2009).

For Latinas, there may be additional reasons why previous HIV testing was not reported, such as a lack of awareness or misunderstanding around partner risk, HIV stigma, barriers accessing medical care, and insufficient effective prevention strategies and initiatives for Latinas, especially ones targeting younger Latinas and those foreignborn (Vega, Klukas, Valera \& Montenegro, 2015; Cianelli et al., 2010; Wohl, Tejero \& Frye, 2009). Self-reported HIV risk behaviors, particularly partner risk, among Latinas in Florida vary by country of birth (Taveras et al., 2016). A greater understanding of partner risk among Latinas may increase perceived HIV susceptibility and HIV testing behaviors in this population (Cianelli et al., 2010). There may be a correlation between frequency of HIV testing and the perceived susceptibility and report of HIV risk. However, this information was not captured in the HIV counseling and testing forms.

More than three quarters $(76 \%)$ of the testing events were for women with previous HIV testing which was associated with increased report of risk behaviors, alluding to some adherence to CDC's HIV testing recommendations (CDC, 2006). However, testing events among Latinas were less likely to include previous HIV testing compared to records for NHW and NHB women, which is consistent with the national data (CDC, 2015a). These results suggest that testing among Latinas is suboptimal given that Latina women are more than three times as likely to be infected with HIV as NHW women (CDC, 2016). This may be the result of the robust effort to target NHB women in the state of Florida, which has not been addressed in a comparable capacity for Latinas 
(Florida Department of Health HIV/AIDS Section, n.d.a; Florida Department of Health HIV/AIDS Section, n.d.b). HIV testing messages and services targeted to MSM and black communities may be less effective among Latinas, especially young Latinas. Current prevention strategies and initiatives for Latinas in Florida are scarce, and evaluation data on what does exist are limited (Florida Department of Health HIV/AIDS Section, n.d.a; Florida Department of Health HIV/AIDS Section, n.d.b). In addition, the promotion of routine testing should focus on all women, including young Latinas, in order to encourage greater awareness of their HIV status and regular HIV testing, in accordance with current CDC HIV testing recommendations (CDC, 2006; CDC, 2001). Latinos are the fastest growing minority population in the US. They are also culturally diverse and differ in national origin, mode of HIV transmission, HIV behavioral risk factors, perception of risk, use of prevention services, and timeliness of HIV testing (CDC, 2015b; CDC, 2007; Espinoza et al., 2007; Garcia, Betancourt \& Scaccaborrozzi, 2015). The diversity among Latinos should be considered in the planning of effective HIV prevention, care and treatment programs, and ongoing data should be collected to evaluate the effectiveness of programming for this target population (Gant et al., 2014; Garcia, Betancourt \& Scaccaborrozzi, 2015). HIV testing is a critical step in the HIV prevention continuum, the HIV care continuum, and in the provision of appropriate and effective prevention care and treatment services to populations disproportionately affected by HIV (McNairy \& El-Sadr, 2014). Enhancing HIV testing services may result in better addressing the three primary goals of the National HIV/AIDS Strategy: 1) reducing the number of people who become infected with HIV; 2) increasing access to care and improving health outcomes for people living with HIV; and 3) reducing HIV- 
related health disparities (The White House Office of the Press Secretary, 2013; Gant et al., 2014; CDC, 2011b; Sionean et al., 2014; Office of National AIDS Policy, 2010; Office of National AIDS Policy, 2015).

HIV testing is considered a High Impact Prevention (HIP) activity by the CDC (CDC, 2011b). In the current study, testing event records of women with previous HIV testing included significantly more risk behaviors compared to testing event records of women without previous HIV testing suggesting that previous testing encounters did not result in lower levels of risk behavior. Current HIV testing and counseling strategies, especially for those testing negative, may not be effective at reducing HIV risk, and therefore, a continued need exists to develop innovative and culturally appropriate risk reduction strategies to prevent new HIV infections (CDC, 2013b; Gant et al., 2014; CDC, 2013c; Sionean et al., 2014; Craig et al., 2012). The rationale for HIV testing suggests that previous testing should increase awareness of perceived risk and the need to test for HIV regularly (Ebrahim, Anderson, Weidle \& Purcell, 2004).

Finally, the collection of data from the large number of people testing in publicly funded HIV testing sites represents an opportunity to collect information about prevention efforts. For example, a history of exposure to previous primary HIV prevention activities (i.e. use of Pre Exposure Prophylaxis [PrEP] and referral and receipt of HIV prevention services) is not captured but could be captured in the HIV testing database. Additional information about factors affecting health disparities such as psychosocial service needs addressing intimate partner violence, mental health and substance abuse treatment would also be useful (CDC, Health Resources and Services 
Administration, National Institutes of Health, American Academy of HIV Medicine, Association of Nurses in AIDS Care, International Association of Providers of AIDS Care, the National Minority AIDS Council, and Urban Coalition for HIV/AIDS Prevention Services, 2014). Recommendations for HIV prevention with adults and adolescents with HIV in the United States, 2014; CDC, 2015c; Stallworth et al., 2009). The CDC continues to encourage state and local health departments to establish protocols to ensure high quality data (CDC, 2006; CDC, 2013c; CDC, Health Resources and Services Administration, National Institutes of Health, American Academy of HIV Medicine, Association of Nurses in AIDS Care, International Association of Providers of AIDS Care, the National Minority AIDS Council, and Urban Coalition for HIV/AIDS Prevention Services, 2014). Enhancing the HIV testing process and the data collected could facilitate the monitoring and evaluation of HIV program performance while addressing indicators of both the HIV prevention and care continuums.

This study had several limitations. First, the dataset only included information on HIV testing conducted at publicly funded HIV testing sites. There may be differences in the women testing in private versus public HIV testing locations because public HIV testing requires no insurance. Thus, results may not be generalizable to the private setting. Second, previous HIV testing and HIV risk behaviors were self-reported. Social desirability bias has been found to cause an underreporting of undesirable behaviors such as HIV risk behaviors and an increase in reporting favorable behaviors such as HIV testing (Sionean et al., 2014). It is also likely that some women were unaware of risk behaviors among partners and thus may have underreported partner risk. Important 
behaviors such as engagement in prevention services and consistent condom use are not captured in the testing database. Third, country of birth was missing for a notable number of records of Latina women and even more so for NHW women, limiting the analysis that could be conducted to determine variations in testing behaviors and positivity among foreign-born and US-born women. Estimates for HIV incidence could not be determined utilizing this dataset because positivity included both previous and newly identified HIV positive individuals; of testing events among Latinas with an HIV positive test result, almost half (48.9\%) previously tested positive (Florida Department of Health, 2013b). Finally, as indicated in our methods section, pregnant women were excluded from this analysis due to concerns about referral bias; thus, the reported risk and demographic profile represents non-pregnant Latinas.

\section{Conclusions}

Florida remains disproportionately affected by HIV, with the second highest rate of newly diagnosed HIV infections and third highest number of adults (age 13+) living with a diagnosis of HIV infection through the end of 2015 in the United States (CDC, 2016a). The current study suggests that Latinas, especially younger Latinas, are underutilizing HIV testing services. There is a critical need to increase strategies and initiatives targeted to Latinas, including those addressing partner risk, in order to increase the proportion of Latinas tested for HIV in Florida and the numbers of young Latinas accessing additional prevention services. In addition, culturally competent, effective risk reduction activities need to be integral components of the HIV testing process. Testing and counseling data could prove to be very valuable in the evaluation of HIV testing 
services provided to Latinos in the State of Florida. It is important to have established monitoring and evaluation practices, such as regular examination of counseling and testing data, to appropriately measure prevention effectiveness and consequently progress toward the goals of the National HIV/AIDS Strategy (CDC, 2006; Sionean et al., 2014).

\section{References}

CDC. (2001). Revised Guidelines for HIV Counseling, Testing and Referral. Morbidity and Mortality Weekly Report, 50(RR19), 1-58. Retrieved from http://www.cdc.gov/mmwr/preview/mmwrhtml/rr5019a1.htm.

CDC. (2003). Late versus early testing of HIV - 16 sites, United States 2000 - 2003. Morbidity and Mortality Weekly Report, 52(25), 581-586. Retrieved from http://www.cdc.gov/mmwr/preview/mmwrhtml/mm5225a2.htm.

CDC. (2006). Revised recommendations for HIV testing of adults, adolescents, and pregnant women in health-care settings. Morbidity and Mortality Weekly Report, 55(RR14), 1-17. Retrieved from http://www.cdc.gov/mmwr/pdf/rr/rr5514.pdf.

CDC. (2007). HIV/AIDS among Hispanics-United States, 2001-2005. Morbidity and Mortality Weekly Report, 56(40), 1052-1057.

Retrieved from http://www.cdc.gov/mmwr/pdf/wk/mm5640.pdf.

CDC. (2011a). Vital signs: HIV prevention through care and treatment - United States. Morbidity and Mortality Weekly Report, 60(47), 1618-1623. Retrieved from http://www.cdc.gov/mmwr/preview/mmwrhtml/mm6047a4.htm.

CDC. (2011b). High-impact prevention: CDC's approach to reducing HIV infections in the United States. Retrieved from http://www.cdc.gov/hiv/pdf/policies_NHPC_Booklet.pdf.

CDC. (2013a). HIV testing trends in the United States, 2000-2011. Retrieved from http://www.cdc.gov/hiv/pdf/testing_trends.pdf

CDC. (2013b). Monitoring selected national HIV prevention and care objectives by using HIV surveillance data-United States and 6 dependent areas-2011. HIV Surveillance Supplemental Report, 18(5). Retrieved from http://www.cdc.gov/hiv/pdf/2011_monitoring_hiv_indicators_hssr_final.pdf. 
CDC. (2013c). HIV Testing at CDC Funded Sites, United States, Puerto Rico and the U.S. Virgin Islands, 2011. Retrieved from http://www.cdc.gov/hiv/pdf/hiv_testing_report_2011_12.13.13_version3.pdf.

CDC, Health Resources and Services Administration, National Institutes of Health, American Academy of HIV Medicine, Association of Nurses in AIDS Care, International Association of Providers of AIDS Care, the National Minority AIDS Council, and Urban Coalition for HIV/AIDS Prevention Services. Recommendations for HIV prevention with adults and adolescents with HIV in the United States, 2014. (2014). Retrieved from http://stacks.cdc.gov/view/cdc/26062.

CDC. (2015a). HIV infection, risk, prevention, and testing behaviors among heterosexuals at increased risk of HIV infection-National HIV Behavioral Surveillance, 20 U.S. Cities, 2013. HIV Surveillance Special Report, 13.

Retrieved from http://www.cdc.gov/hiv/pdf/library/reports/surveillance/cdc-hivHSSR_NHBS_HET_2013.pdf

CDC. (2015b). HIV among Latinos. Retrieved from http://www.cdc.gov/hiv/pdf/risk_latino2.pdf.

CDC. (2015c). Establishing a holistic framework to reduce inequities in HIV, viral hepatitis, STDs, and tuberculosis in the United States: an NCHHSTP white paper on social determinants of health, 2010. Retrieved from http://www.cdc.gov/socialdeterminants/docs/SDH-White-Paper-2010.pdf.

CDC. (2016a). HIV Surveillance Report, 2015, 27.

Retrieved from http://www.cdc.gov/hiv/library/reports/hiv-surveillance.html.

CDC. (2016b). Implementing HIV Testing in nonclinical settings. Retrieved from https://www.cdc.gov/hiv/pdf/testing/cdc_hiv_implementing_hiv_testing_in_nonclinical_s ettings.pdf.

Chen, N.E., Gallant, J.E., Page, K.R. (2012). A systematic review of HIV/AIDS survival and delayed diagnosis among Hispanics in the United States. Journal of Immigrant and Minority Health, 14(1), 65-81.

Cianelli, R., Villegas, N., Gonzalez-Guarda, R., Kaelber, L., \& Peragallo, N. (2010). HIV susceptibility among Hispanic women in south Florida. Journal of Community Health Nursing, 27(4), 207-2015.

Craig, S.L., Beaulaurier, R.L., Newman, F.L., De La Rosa, M., Brennan, D.J. (2012). Health and cultural determinants of voluntary HIV testing and counseling among middleaged and older Latina women. Journal of Women and Aging, 24(2), 97-112. 
Ebrahim SH, Anderson JE, Weidle P, Purcell DW. (2004). Race/ethnic disparities in HIV testing and knowledge about treatment for HIV/AIDS: United States, 2001. AIDS Patient Care STDS, 18(1), 27-33.

Espinoza, L., Hall, I., Hardnett, F., Selik, R. M., Ling, Q., \& Lee, L. M. (2007). Characteristics of persons with heterosexually acquired HIV infection, United States 1999-2004. American Journal of Public Health, 97(1), 144-149.

Florida Department of Health. (n.d.). Florida Charts. Retrieved from http://www.floridacharts.com/charts/SpecReport.aspx ?RepID=7200\&tn=25.

Florida Department of Health (2013a). HIV and AIDS among minorities in Florida. Retrieved from http://www.floridahealth.gov/diseases-andconditions/aids/surveillance/epi-profiles/epiprof-minorities-2012-revised.pdf.

Florida Department of Health. (2013b). HIV Counseling and Testing Update, 2012. Retrieved 2014 from http://www.floridahealth.gov/diseases-andconditions/aids/prevention/_documents/Counseling_testing/2012-counseling/2012ANNUAL-Update.pdf.

Florida Department of Health. (2014). Epidemiology of HIV among women in Florida reported through 2014. Retrieved from http://www.floridahealth.gov/diseases-andconditions/aids/surveillance/epi-slide-sets.html.

Florida Department of Health HIV/AIDS Section. (n.d.a). Interventions for high risk negatives. Retrieved from http://www.floridahealth.gov/diseases-andconditions/aids/prevention/interventions-high-risk-neg.html.

Florida Department of Health HIV/AIDS Section. (n.d.b). Minority HIV/AIDS Initiatives. Retrieved November 2015 from http://www.floridahealth.gov/diseases-and conditions/aids/administration/minority-initiatives.html.

Gant, Z., Bradley, H., Hu, X., Skarbinski, J., Hall, I., Lansky, A. (2014). Hispanics or Latinos living with diagnosed HIV : progress along the continuum of HIV care - United States, 2010. Morbidity and Mortality Weekly Report, 63(40), 886-890. Retrieved from http://www.cdc.gov/mmwr/preview/mmwrhtml/mm6340a2.htm.

Garcia, D., Betancourt, G., Scaccaborrozzi, L. (2015). The state of HIV/AIDS among Hispanics/Latinos in the US and Puerto Rico. Retrieved from www.latinoaids.org/publications/HIVbrief2015_Eng.pdf.

Hall, H., Walker, F., Shah, D., \& Belle, E. (2012). Trends in HIV diagnosis and testing among US adolescents and young adults. AIDS and Behavior, 16(1), 36-43. 
Institute of Medicine. (2001). Individuals and families: Models and interventions. Health and behavior: The interplay of biological, behavioral and societal influences, (pp.183). Washington: National Academy of Press.

Kinsler, J., Lee, S., Sayles, J., Newman, P.A., Diamant, A., Cunningham, W. (2009). The impact of acculturation on utilization of HIV prevention services and access to care among an at-risk Hispanic population. Journal of Health Care for the Poor Underserved, 20(4), 996-1011.

Marks, G., Crepaz, N., Senterfitt, J. W., \& Janssen, R. S. (2005). Meta-analysis of highrisk sexual behavior in persons aware and unaware they are infected with HIV in the United States: Implications for HIV prevention programs. Journal of Acquired Immune Deficiency Syndromes, 39(4), 446-453.

McNairy, M., El-Sadr, W. (2014). A paradigm shift: focus on the HIV prevention continuum. Journal of Clinical Infectious Disease, Supplement 1, S12-S15. Retrieved from http://cid.oxfordjournals.org/content/59/suppl_1/S12.full.pdf+html.

Office of National AIDS Policy. (2010). National HIV/AIDS Strategy. Retrieved from http://www.whitehouse.gov/administration/eop/onap/nhas.

Office of National AIDS Policy. (2015). National HIV/AIDS Strategy for the United States: Updated 2020. Retrieved from https://www.aids.gov/federal-resources/nationalhiv-aids-strategy/nhas-update.pdf

Sheehan, D., Trepka, M., Dillion, F. (2014). Latinos in the United States on the HIV/AIDS care continuum by birth country/region: a systematic review of the literature. International Journal of STD \& AIDS, 26(1), 1-12. Retrieved from http://std.sagepub.com/content/26/1/1.full.pdf+html.

Sionean, C., Le, B.C., Hageman, K., Oster, A.M., Wejnert, C., Hess, K.L., Paz-Bailey, G. (2014). HIV risk, prevention, and testing behaviors among heterosexuals at increased risk for HIV infection--National HIV Behavioral Surveillance System, 21 U.S. cities, 2010. Morbidity and Mortality Weekly Report Surveillance Summary, 63(14), 1-39. Retrieved from http://www.ncbi.nlm.nih.gov/pubmed/25522191.

Stallworth, J. M., Herbst, J. H., Alvarez, M. E., Romaguera, R. A., Amaro, H., Dean, H. D. (2009). Special supplement on Hispanics/Latinos and HIV/AIDS. Introduction. AIDS Education and Prevention, 21(Supplement B), 3-6.

Taveras, J., Trepka, M., Khan, H., Madhivanan, P., Gollub, E., Devieux, J. (2016). HIV risk behaviors among Latina women tested for HIV in Florida by country of birth, 2012. Journal of Immigrant and Minority Health, 18(5), 1104-1114. Retrieved from http://link.springer.com/article/10.1007/s10903-015-0260-7?no-access=true. 
The White House Office of the Press Secretary. (2013). FACT SHEET: Accelerating improvements in HIV prevention and care in the United States through the HIV care continuum initiative. Retrieved from http://www.whitehouse.gov/the-pressoffice/2013/07/15/fact-sheet-accelerating-improvements-hiv-prevention-and-care-unitedstat.

Trepka, M., Fennie, K., Sheehan, D., Lutfi, K., Maddox, L., Lieb, S. (2014). Late HIV diagnosis: differences by rural/urban residence, Florida, 2007-2011. AIDS Patient Care and STDS, 28(4), 188-197.

United Stated Census Bureau. (2015). Population Estimates. Retrieved from http://factfinder.census.gov/bkmk/table/1.0/en/PEP/2014/PEPASR6H?slice=hisp hisp!ye ar est72014.

Vega, M. Y., Klukas, E., Valera, E., \& Montenegro, J. (2015). The state of Latinos in the deep south: Being visible by piercing the stigma veil. New York, NY: Latino Commission on AIDS. Retrieved from https://www.latinoaids.org/publications/DeepSouthReport2015.pdf.

Wohl, A.R., Tejero, J., Frye, D.M. (2009). Factors associated with late HIV testing for Latinos diagnosed with AIDS in Los Angeles. AIDS Care, 21(9), 1203-1210. 
Tables and figures 
Table 1: Previous HIV testing and positivity by race/ethnicity among non-pregnant women tested for HIV in Florida 2012

\begin{tabular}{|c|c|c|c|c|c|c|c|c|}
\hline Race/ethnicity & Total & $\begin{array}{l}\text { Latina } \\
\text { n }(\%)\end{array}$ & $\begin{array}{l}\text { NHW } \\
\text { n (\%) }\end{array}$ & $\begin{array}{l}\text { NHB } \\
\text { n }(\%)\end{array}$ & $\begin{array}{l}\text { Other } \\
\text { n }(\%)\end{array}$ & $\begin{array}{l}\text { Missing } \\
\text { n (\%) }\end{array}$ & $\begin{array}{l}\text { Latina } \\
\text { vs. NHW } \\
p \text {-value }\end{array}$ & $\begin{array}{l}\text { Latina } \\
\text { vs. NHB } \\
p \text {-value }\end{array}$ \\
\hline Total n (\%) & 184,037 & $41,117(22.3)$ & $47,926(26.0)$ & $87,569(47.6)$ & $1,753(1.0)$ & $5,672(3.1)$ & & \\
\hline $\begin{array}{l}\text { Mean age (standard } \\
\text { deviation) }\end{array}$ & 30.5 & $32.1(11.6)$ & $30.3(13.0)$ & $30.0(11.4)$ & $30.9(11.5)$ & $30.1(11.6)$ & $<0.0001$ & $<0.0001$ \\
\hline Age group (years) & & & & & & & $<0.0001$ & $<0.0001$ \\
\hline $13-19$ & $24,522(13.3)$ & 4,379 (10.7) & 6,974 (14.6) & $12,084(13.8)$ & 202 (11.5) & $883(15.6)$ & & \\
\hline $20-29$ & $81,231(44.1)$ & $16,042(39.0)$ & $21,103(44.0)$ & $40,811(46.6)$ & $791(45.1)$ & $2,484(43.8)$ & & \\
\hline $30-39$ & $39,605(21.5)$ & $10,748(26.1)$ & $9,698(20.2)$ & $17,590(20.1)$ & $379(21.6)$ & $1,190(21.0)$ & & \\
\hline $40-49$ & $23,158(11.5)$ & $6,038(14.7)$ & $6,182(12.9)$ & $10,048(11.5)$ & $234(13.4)$ & 647 (11.4) & & \\
\hline 50 and over & $15,530(8.4)$ & $3,910(9.5)$ & $3,969(8.3)$ & $7,036(8.0)$ & $147(8.4)$ & $468(8.3)$ & & \\
\hline Country of birth & & & & & & & $<0.0001$ & $<0.0001$ \\
\hline US-born & $79,116(43.0)$ & $9,333(22.7)$ & $19,640(41.0)$ & $47,979(54.8)$ & $435(24.8)$ & $1,729(30.5)$ & & \\
\hline Foreign-born & $42,605(23.2)$ & $25,363(61.7)$ & $2,528(5.3)$ & $12,534(26.1)$ & 805 (45.9) & $1,375(24.2)$ & & \\
\hline Missing & $62,316(33.9)$ & $6,421(15.6)$ & $25,758(53.8)$ & $27,056(30.9)$ & $513(29.3)$ & $2,568(45.3)$ & & \\
\hline Previous HIV testing & & & & & & & $<0.0001$ & $<0.0001$ \\
\hline Yes & $139,854(76.0)$ & $28,536(69.4)$ & $34,703(72.4)$ & $71,689(81.9)$ & $1,132(64.6)$ & $3,794(66.9)$ & & \\
\hline No & $37,323(20.3)$ & $11,019(26.8)$ & $10,940(22.8)$ & $13,621(15.6)$ & $540(30.8)$ & $1,203(21.2)$ & & \\
\hline Don't Know/refused & $6,860(3.7)$ & $1,562(3.8)$ & $2,283(4.8)$ & $2,259(2.6)$ & $81(4.6)$ & $675(11.9)$ & & \\
\hline Positivity & & & & & & & 0.323 & $<0.0001$ \\
\hline No & $182,985(99.4)$ & 40,969 (99.6) & 47,771 (99.7) & $86,858(99.2)$ & $1,749(99.8)$ & $5,638(99.4)$ & & \\
\hline Yes & $928(0.5)$ & $125(0.3)$ & $138(0.3)$ & $630(0.7)$ & $4(0.2)$ & $31(0.6)$ & & \\
\hline Indeterminate/missing ${ }^{\mathrm{b}}$ & $124(0.1)$ & $23(0.1)$ & $17(0.0)$ & $81(0.1)$ & $0(0.0)$ & $3(0.1)$ & & \\
\hline
\end{tabular}

$\mathrm{NHB}=$ Non-Hispanic Black, NHW = Non-Hispanic White

${ }^{a}$ Chi-squared statistics were used to compare the variables. The statistical significance level alpha was set to 0.05 .

${ }^{\mathrm{b}}$ Indeterminate/missing HIV tests without a confirmatory result 
Table 2. HIV risk behaviors and demographics by previous HIV testing among non-pregnant women tested for HIV in Florida 2012

\begin{tabular}{|c|c|c|c|c|}
\hline & $\begin{array}{c}\text { Previous HIV } \\
\text { testing } \\
\text { n }(\%)\end{array}$ & $\begin{array}{c}\text { No Previous HIV } \\
\text { testing } \\
\text { n }(\%)\end{array}$ & $\begin{array}{c}\text { Not Sure of } \\
\text { Previous HIV } \\
\text { testing } \\
\text { n }(\%)\end{array}$ & $\begin{array}{l}p \text {-value }{ }^{\mathrm{a}} \\
(\alpha=0.05)\end{array}$ \\
\hline Total n (\%) & $139,854(76.0)$ & $37,323(20.3)$ & $6,680(3.7)$ & \\
\hline Mean age (standard deviation) & $31.0(10.7)$ & $28.7(13.7)$ & $31.7(12.5)$ & 0.2747 \\
\hline Age group (years) & & & & $<.0001$ \\
\hline 13-19 & $12,284(8.8)$ & $11,331(30.4)$ & $907(13.2)$ & \\
\hline 20-29 & $64,716(46.3)$ & $13,726(36.8)$ & $2,789(40.7)$ & \\
\hline 30-39 & $33,804(24.2)$ & $4,348(11.7)$ & $1,453(21.2)$ & \\
\hline $40-49$ & $18,691(13.4)$ & $3,529(9.5)$ & $929(13.5)$ & \\
\hline 50 and over & $10,359(7.4)$ & $4,389(11.8)$ & $782(11.4)$ & \\
\hline Any personal risk & $127,671(91.3)$ & $31,709(85.0)$ & $5,814(84.8)$ & $<.0001$ \\
\hline Sex (vaginal or anal) with a male & $127,109(90.9)$ & $31,591(84.6)$ & $5,786(84.3)$ & $<.0001$ \\
\hline $\begin{array}{l}\text { Sex for drugs/money/other items (anal, } \\
\text { vaginal or oral) }\end{array}$ & $5,630(4.0)$ & $692(1.9)$ & $257(3.8)$ & $<.0001$ \\
\hline STD diagnosis & $11,589(8.3)$ & $1,612(4.3)$ & $415(6.1)$ & $<.0001$ \\
\hline Injection drug use & $4,661(3.3)$ & $775(2.1)$ & $353(5.2)$ & $<.0001$ \\
\hline Any partner risk & $7,414(5.3)$ & $1,266(3.4)$ & $450(6.6)$ & $<.0001$ \\
\hline $\begin{array}{l}\text { Sex (vaginal or anal) with HIV-positive } \\
\text { person }\end{array}$ & $1,826(1.3)$ & $235(0.6)$ & $40(0.6)$ & $<.0001$ \\
\hline Sex (vaginal or anal) with an IDU & $4,625(3.3)$ & $794(2.1)$ & $376(5.5)$ & $<.0001$ \\
\hline
\end{tabular}




\section{Sex (vaginal or anal) with a MSM}

Any personal or partner risk

Positivity

No

Yes

Indeterminate/ Missing ${ }^{\mathrm{b}}$

\begin{abstract}
$1,650(1.2)$
\end{abstract}
$127,848(91.4)$

$315(0.8)$

$<.0001$

(9)

$138,983(99.4)$

$761(0.5)$

$110(0.1)$
$31,749(85.1)$

$5,823(84.9)$

$<.0001$

$<.0001$

$37,194(99.7) \quad 6,808(99.2)$

$121(0.3) \quad 46(0.7)$

$8(0.0) \quad 6(0.1)$

STD = sexually transmitted disease, HIV = human immunodeficiency virus, IDU = injection drug user, MSM = man that has sex with men ${ }^{a}$ Chi-squared statistics were used to compare the variables.

bIndeterminate/missing HIV tests without a confirmatory result. 
Table 3. Adjusted odds ratio estimates for previous HIV testing and positive HIV test result among non-pregnant women tested for HIV in Florida 2012

\begin{tabular}{|c|c|c|}
\hline & $\begin{array}{l}\text { Previous HIV testing OR } \\
(95 \% \text { CI })\end{array}$ & HIV Positivity OR (95\% CI) \\
\hline \multicolumn{3}{|c|}{ Model 1a Independent variable race/ethnicity } \\
\hline Latina & $0.90(0.87,0.94)$ & $0.88(0.68,1.15)$ \\
\hline Non-Hispanic Black & $1.85(1.79,1.91)$ & $2.42(1.98,2.96)$ \\
\hline Other & $0.73(0.65,0.81)$ & $0.74(0.27,2.03)$ \\
\hline Missing & $1.20(1.11,1.29)$ & $1.81(1.19,2.75)$ \\
\hline Non-Hispanic White & Referent & Referent \\
\hline \multicolumn{3}{|c|}{ Model $2^{\mathrm{b}}$ Independent variable 'personal risk' and 'partner risk' } \\
\hline Any personal risk & $1.62(1.56,1.68)$ & $0.51(0.43,0.61)$ \\
\hline No personal risk & Referent & Referent \\
\hline Any partner risk & $1.36(1.28,1.44)$ & $3.86(3.13,4.76)$ \\
\hline No partner risk & Referent & Referent \\
\hline \multicolumn{3}{|c|}{ Model $3^{b}$ Independent variable previous HIV testing } \\
\hline Previous HIV testing & $\mathrm{n} / \mathrm{a}$ & Referent \\
\hline No previous HIV testing & $\mathrm{n} / \mathrm{a}$ & $0.93(0.78,1.10)$ \\
\hline
\end{tabular}

${ }^{\mathrm{a}}$ Odds ratios adjusted for age

${ }^{\mathrm{b}}$ Odds ratios adjusted for age and race/ethnicity 
Table 4. HIV risk behaviors and demographics by HIV test result among women non-pregnant and tested for HIV in Florida 2012

\begin{tabular}{|c|c|c|c|}
\hline & $\begin{array}{c}\text { Positive HIV Test } \\
\text { n }(\%)\end{array}$ & $\begin{array}{c}\text { Negative HIV Test } \\
\text { n(\%) }\end{array}$ & $\begin{array}{l}p \text {-value }{ }^{\mathrm{a}} \\
(\alpha=0.05)\end{array}$ \\
\hline Total n (\%) & 928 & 182,985 & \\
\hline $\begin{array}{l}\text { Mean age in years } \\
\text { (standard deviation) }\end{array}$ & $39.2(11.7)$ & $30.5(11.5)$ & 0.2236 \\
\hline Age group (years) & & & $<0.0001$ \\
\hline 13-19 & $28(3.0)$ & $24,486(13.4)$ & \\
\hline $20-29$ & $189(20.4)$ & $81,015(44.3)$ & \\
\hline $30-39$ & $261(28.1)$ & $39,310(21.5)$ & \\
\hline $40-49$ & $252(27.2)$ & $22,867(12.5)$ & \\
\hline 50 and over & $198(21.3)$ & $15,307(8.4)$ & \\
\hline Race/ethnicity & & & $<0.0001$ \\
\hline Latina & $125(13.5)$ & $40,969(22.4)$ & \\
\hline Non-Hispanic White & 138 (14.9) & $47,771(26.1)$ & \\
\hline Non-Hispanic Black & $630(67.9)$ & $86,858(47.5)$ & \\
\hline Other & $4(0.4)$ & $1,749(1.0)$ & \\
\hline Missing & $31(3.3)$ & $5,638(3.1)$ & \\
\hline Any personal risk & 737 (79.4) & $164,356(89.8)$ & $<0.0001$ \\
\hline $\begin{array}{l}\text { Sex (vaginal or anal) with } \\
\text { a male }\end{array}$ & $727(78.3)$ & $163,660(89.4)$ & $<0.0001$ \\
\hline $\begin{array}{l}\text { Sex for drugs/money/other } \\
\text { items (anal, vaginal or } \\
\text { oral) }\end{array}$ & $74(8.0)$ & $6,494(3.6)$ & $<0.0001$ \\
\hline STD diagnosis & $61(6.6)$ & $13,543(7.4)$ & 0.3365 \\
\hline Injection drug use & $41(4.4)$ & $5,744(3.1)$ & 0.0260 \\
\hline Any partner risk & $143(15.4)$ & $8,973(4.9)$ & $<0.0001$ \\
\hline $\begin{array}{l}\text { Sex (vaginal or anal) with } \\
\text { HIV-positive person }\end{array}$ & $106(11.4)$ & $1,986(1.1)$ & $<0.0001$ \\
\hline $\begin{array}{l}\text { Sex (vaginal or anal) with } \\
\text { an IDU }\end{array}$ & $37(4.0)$ & $5,752(3.1)$ & 0.1421 \\
\hline $\begin{array}{l}\text { Sex (vaginal or anal) with } \\
\text { a MSM }\end{array}$ & $11(1.2)$ & $2,009(1.1)$ & 0.7988 \\
\hline $\begin{array}{l}\text { Any personal or partner } \\
\text { risk }\end{array}$ & $738(79.5)$ & $164,581(89.9)$ & $<0.0001$ \\
\hline Previous HIV testing & & & $<0.0001$ \\
\hline
\end{tabular}




\begin{tabular}{lcc}
\hline Yes & $761(82.0)$ & $138,983(76.0)$ \\
No & $121(13.0)$ & $37,194(20.3)$ \\
Don't know/refused & $46(5.0)$ & $6,808(3.7)$ \\
\hline
\end{tabular}

STD: sexually transmitted disease; HIV: human immunodeficiency virus; IDU: injection drug user; MSM: man that has sex with men

${ }^{a}$ Chi-squared statistics were used to compare the variables. 


\title{
MANUSCRIPT 3
}

\begin{abstract}
Objective: Over the years the number of perinatal infections in the United States (US) has continued to decline, but the prevalence of female adults and adolescents living with diagnosed HIV infection has continued to rise. Therefore, opportunities still exist to prevent mother-to child HIV transmission. The purpose of this study was to identify demographics, reported HIV risk behaviors, and testing behaviors among pregnant women tested at publicly funded sites in Florida, and to compare these characteristics by HIV testing site type. Methods: Multivariable analyses were conducted to examine demographics, HIV risk and testing behaviors among records of pregnant women publicly tested for HIV in Florida. Results: The testing records indicated that Latina and non-Hispanic black (NHB) women had decreased odds of reporting partner risk compared to those from non-Hispanic white (NHW) women (Latina: adjusted odds ratio [AOR] 0.20, 95\% confidence interval [CI]: 0.14-0.28; and NHB: AOR 0.14, 95\% CI: 0.10-0.21), and women tested in prisons/jails had higher odds of reporting previous HIV testing compared to prenatal care sites (AOR 1.86, 95\% CI: 1.03-3.39). Conclusion: An understanding of HIV risk and testing behaviors among pregnant women by site type can be used to enhance current testing and prevention strategies targeted to pregnant women and facilitate timely linkage to care.
\end{abstract}

KEYWORDS: HIV testing, human immunodeficiency virus, pregnant women, perinatal, mother-to-child transmission 
Introduction

Over the years the number of perinatal infections in the United States has continued to decline (188 in 2010 and 86 in 2015), but the prevalence of female adults and adolescents living with diagnosed HIV infection continues to rise (163.8 per 100,000 in 2010 and 171.0 per 100,000 in 2015) (Centers for Disease Control and Prevention [CDC], 2016a). It is estimated that 8,500 women living with HIV give birth every year (CDC, 2016b). As there continue to be HIV-positive women of childbearing age, it is important to continue robust HIV prevention efforts for this population (Nesheim et al., 2012). Even with decreased rates of mother-to-child transmission, studies demonstrate that opportunities to prevent transmission still exist by enhancing HIV testing, care and treatment of HIV-infected pregnant women and understanding birth trends and patterns of care among these women (Trepka et al., 2017; Moyer, 2013; Sansom et al., 2007; McKenna \& Hu, 2007; Nesheim et al., 2012). HIV testing and the early identification of HIV infection of pregnant women through universal prenatal screening is an important component of successful prevention of mother-to-child transmission of HIV (Nesheim et al., 2012). The most recent recommendations for the HIV screening of pregnant women emphasize that HIV testing should be part of routine prenatal care (CDC, 2001).

In 1988, Florida was one of the first states, with high rates of reported HIV infection cases, to authorize comprehensive legislation addressing HIV/AIDS (Florida Department of Health [FDOH], 2013a). This authorization was done through the enactment of the Omnibus AIDS Act which aimed to promote patient-initiated HIV testing through informed consent and ensured confidentiality. However, pregnancy is an 
exception to this legal requirement for written informed consent. Since 2005, the Florida law was amended and aligned with CDC recommendations for HIV screening on an "opt out" basis (consent is inferred unless the patient declines testing) at all health care settings as part of routine medical care (CDC, 2006; FDOH, 2013a). Additional requirements in Florida mandate repeat HIV testing at 28-32 weeks of gestation (FDOH, 2013a). Of the 2,444 pediatric HIV cases reported in Florida, through 2014, $95 \%$ were perinatally acquired. The most common mode of HIV exposure for mothers of infants, who were perinatally infected and were born in Florida between 1994 and 2014 was heterosexual contact followed by mother's risk not specified and injection drug use (69\%, $16 \%$ and $14 \%$ respectively; FDOH, 2015). Of the HIV-positive mothers who gave birth in Florida between 2007 and 2014, 57\% knew their HIV status prior to pregnancy, 16\% during pregnancy, $7 \%$ at delivery and 19\% after birth (FDOH 2015). Even with much information and progress addressing perinatal transmission in the US, studies and information examining HIV testing site types among pregnant women are limited at best, and reports on publicly funded HIV testing do not focus on pregnant women (CDC 2015, FDOH, 2013b, Lawrence, Liu \& Towner, 2009). There is a need to explore and understand patterns of and reasons for receipt of HIV testing among pregnant women by site type, which can be used to improve current prevention strategies targeted to pregnant women.

The purpose of this study was to identify reported HIV risk behaviors, testing behaviors and demographics among pregnant women tested at publicly funded sites in Florida, and to compare these characteristics by HIV testing site type. 
Methods

\section{Study design and population}

This cross-sectional study used de-identified data from the Florida HIV Counseling and Testing Database, which included demographic and risk behavior information from all records of women, 13 years of age and older, tested for HIV in publicly-funded HIV counseling and testing sites in Florida, during 2012, totaling 209,954 records. These data were recorded by trained counselors, who collected demographic and risk behavior information from persons voluntarily testing for HIV on the Department of Health 1628 Testing and Counseling Forms. The captured variables included self-reported risk behaviors during the 12 months prior to testing, race, ethnicity, gender, previous HIV testing, and current testing site. This information was sent to the Florida Department of Health Counseling, Testing and Linkage Data Team, and entered into a database. HIV test results were then additionally included as they became available. Records from transgender individuals were excluded from the sample because of small numbers (59 Latina, $57 \mathrm{NHW}, 120 \mathrm{NHB}$, three belonging to other race/ethnicity, and three had unknown race/ethnicity). Records with missing gender information were also excluded (833). Records of women who responded "yes" to current pregnancy $(24,836)$ were selected and included in the final dataset for analysis.

The dataset was of testing events; therefore, it was possible that some women were tested more than once in the given year, resulting in them being represented more than once in the dataset. However, because the records were de-identified, it was not possible to exclude records for women who tested more than once in 2012. 


\section{Classification of variables}

All variables were categorical except for age, which was recoded into age groups: $13-19,20-29,30-39,40-49$ and 50 years and older. Risk factors were categorized as either personal or partner risk. Personal risk was defined as any factor that would place an individual at risk for HIV based on their own risk behaviors or activities, and partner risk was defined as having vaginal or anal sex with a partner with increased risk of HIV. A woman was considered to have personal risk if she responded "yes" to any of the following within the past 12 months: anal/vaginal/oral sex for drugs/money/other items, diagnosis of sexually transmitted disease (STD), or injection drug use. "Yes" responses to having vaginal or anal sex with an HIV-positive person, an injection drug user (IDU), or a man who has sex with men (MSM) in the past 12 months were considered partner risk (Taveras et al., 2016). Vaginal/anal sex with a male was excluded from personal risk and examined independently because it is expected that among women reporting currently being pregnant, most would also report vaginal/anal sex with a male. HIV testing site types were categorized as prenatal care sites (prenatal/obstetrics [OB] and family planning), STD clinic sites, drug treatment facilities, prison/jail, other non-healthcare, and other healthcare. Other non-health care sites included anonymous HIV testing sites, community-based organizations, county health department field visits, and special projects. Other healthcare sites included tuberculosis clinics, adult health clinics, college/university HIV testing sites, and private/medical doctor [MD] clinics. 


\section{Data analysis}

Descriptive analyses were first performed of demographic characteristics, reported risks, history of previous HIV testing, and HIV test results. Mean ages were compared using independent samples t-tests and analyses of variance. Chi-square tests for categorical variables were performed to identify significant differences in US-born vs. foreign-born, personal risk reported and previous HIV testing by race/ethnicity. Fisher's exact tests were conducted to identify significant differences among categorical variables that had cell sizes $<5$.

Controlling for age, three multivariable analyses were conducted; the dependent variables for each were personal risk, partner risk and previous testing. To examine differences among pregnant women publicly tested for HIV in Florida, adjusted odds ratio (AOR) and $95 \%$ confidence intervals (CIs) were calculated by analyzing dependent variables: 1) by race/ethnicity, 2) nativity (US-born vs. foreign-born), 3) site type, and 4) previous HIV testing. Clustering effects of testing site were handled through a random intercept using SAS Proc Glimmix. SAS software, version 9.3 (SAS Institute, Cary, NC 2002) was used to conduct all analyses. The Florida Department of Health and Florida International University Institutional Review Boards (IRB) deemed this study non-human subjects research.

Results

$\underline{\text { Sample characteristics }}$

Of the 24,836 testing events included in these analyses, $41.1 \%$ were among Latinas, $27.4 \%$ were among NHB, 26.7\% were among NHW, 2.7\% had no recorded 
race/ethnicity (missing), and $2.1 \%$ belonged to "other" race/ethnicity (Table 1 ). The mean age among records of pregnant women was 26.5 years (standard deviation 6.3) and was higher among records from Latinas (mean age 27.2 years) than from NHW and NHB women (NHW mean age 25.6 years, $p<0.0001$; NHB mean age 26.2 years, $p<0.0001$ ). Fewer than half of the testing events (45.8\%) were among foreign-born women, $14.3 \%$ were among US born, and 33.9\% were missing 'country of birth' information. Threequarters of testing events among Latinas, and more than one-third among NHB women were for foreign-born women (75.2\% and 34.0\% respectively). Most testing events (98.4\%) reported vaginal or anal sex with a male in the prior 12 months, while only $7.2 \%$ reported any other personal or partner risk in the past 12 months. Report of previous STD diagnosis in the past 12 months $(4.7 \%)$ was the most frequently reported risk followed by injection drug use $(1.3 \%)$ and vaginal or anal sex with an injection drug user $(1.3 \%)$. The majority of the testing events $(81.7 \%)$ were among women who had previous HIV testing, $13.2 \%$ had no previous testing, and for $5.1 \%$ it was not known if previous testing for HIV had occurred (Table 1).

\section{$\underline{\text { Race/ethnicity among pregnant women with HIV testing }}$}

Significant differences between racial/ethnic groups with respect to reported risks were identified in the bivariate analyses. Personal risk was more frequently reported among testing events from NHW women and NHB women than Latinas $(9.6 \%, 9.1 \%$ and $3.0 \%$ respectively NHW vs. Latina $p<0.0001$; NHB vs. Latina $p<0.0001$ ), and partner risk was significantly more frequently reported among NHW than Latina women $(4.8 \%$ vs. $0.5 \% ; p<0.0001$ ) (Table 1). However, excluding vaginal/anal sex with a male, most 
HIV risk factors were more frequently reported among records from NHW women than Latinas such as vaginal/anal/oral sex for drugs/money/other items (2.3\% vs. $0.4 \% ; p$ $<0.0001)$, injection drug use $(4.3 \%$ vs. $0.2 \% ; p<0.0001)$, vaginal/anal sex with an HIVpositive person $(0.4 \%$ vs. $0.1 \%$; $\mathrm{p}=0.0009)$, vaginal/anal sex with an IDU $(4.1 \%$ vs. $0.3 \% ; p<0.0001)$, and vaginal/anal sex with an MSM (0.5\% vs. $0.1 \% ; p<0.0001)$. However, compared with NHB women, Latina women more frequently reported vaginal/anal sex with an IDU $(0.3 \%$ vs. $0.1 \% ; p=0.0400)$, but less frequently reported STD diagnosis $(2.5 \%$ vs. $8.1 \% ; p<0.0001)$ and vaginal/anal sex with an HIV-positive person $(0.1 \%$ vs. $0.4 \% ; p=0.0012)$.

In multivariate analysis, when controlling for age, records from Latina and NHB women had decreased odds of reporting partner risk than records from NHW women (Latina: AOR 0.20, 95\% CI: 0.14-0.28; and NHB: AOR 0.14, 95\% CI: 0.10-0.21) (Table 2). In addition, HIV testing records among Latinas had fewer documented HIV-positive test result than records among NHB women $(0.1 \%$ vs. $0.4 \% ; p<0.0001)$ and was the same for NHW women $(0.1 \%)$ (Table 1$)$.

\section{Demographics among HIV testing pregnant women by site type}

The majority of testing records of pregnant women were from prenatal care sites (76.9\%) followed by other non-healthcare sites (12.1\%), STD clinic (5.0\%), other healthcare $(3.1 \%)$, drug treatment facilities $(1.7 \%)$, and prison/jails $(1.1 \%)$ (Table 3$)$. Events at STD clinic testing sites were among women with the youngest mean age (24.6 years) and with $21.8 \%$ being in the $13-19$ year age group. Drug treatment testing sites had the greatest percentage $(70.7 \%)$ of women in the $20-29$ year age group and other 
non-health care sites had the highest percentage of women in the 30-39 year and 40-49 year age group (29.1\% and 3.8\% respectively). The race/ethnicity and foreign-born vs. US-born distribution of women varied by HIV testing site with the largest proportion of women tested in prenatal care sites being Latina (45.6\%), NHW at drug treatment sites more frequently $(82.3 \%)$, and NHB at other healthcare sites $(53.3 \%)$. HIV testing events from prison/jail and other healthcare sites were more frequently US-born (85.6\% and $59.4 \%$ respectively), and women who tested at prenatal care sites and other nonhealthcare sites were more frequently foreign-born ( $51.6 \%$ and $47.8 \%$ respectively). $\underline{\text { HIV risk behaviors among pregnant woman by site type }}$

Reported risk behaviors varied by testing site type (personal risk $p<0.0001$ and partner risk $p<0.0001$ ) (Table 3). Drug treatment site records reported the highest percentage anal/vaginal/oral sex for drugs/money/other items (16.4\%), injection drug use (31.9\%), and vaginal/anal sex with an IDU (31.6\%) followed by prison/jail sites $(12.9 \%$, $12.9 \%$ and $10.7 \%$ respectively). STD clinic sites reported the highest percentage of STD diagnosis followed by prison/jail testing sites (17.2\% and $10.0 \%$ respectively). Records from other healthcare sites reported the highest percentage vaginal/anal sex with an HIVpositive person $(2.2 \%)$, and records from drug treatment sites reported the highest percentage vaginal/anal sex with an MSM (1.4\%). In multivariate analysis, when controlling for age, the odds of reporting risk (personal and partner) were greater for all testing site types when compared to prenatal sites (Table 2). 


\section{Previous HIV testing behaviors and HIV positive test result}

Previous HIV testing was less frequently reported among records of NHW women than Latinas and NHB women $(79.5 \%$ vs. $80.9 \%, \mathrm{p}<0.0001$ and $79.5 \%$ vs. $86.2 \%, \mathrm{p}<0.0001$ respectively) (Table 1). In multivariable analysis, after controlling for age, NHB women were more likely to have reported previous HIV testing compared to NHW women (AOR 1.69, 95\% CI: 1.52-1.88) (Table 2). Report of previous HIV testing and HIV positivity varied significantly by HIV testing site type. Most testing event records from prison/jail sites reported previous HIV testing (92.6\%), followed by prenatal care site $(82.7 \%)$ and STD clinics $(81.5 \%)$ (Table 3). Testing event records from drug treatment sites and other non-healthcare sites had the lowest report of previous HIV testing (64.7\% and $77.7 \%)$. HIV testing records from other healthcare and STD clinics had the highest frequency of HIV positive test results $(0.9 \%$ and $0.6 \%$ respectively). In multivariable analysis, after controlling for age, only testing events from prison/jail sites had higher odds of reporting previous HIV testing compared to prenatal care sites (AOR 1.86, 95\% CI: 1.03-3.39) (Table 2). Testing records that report previous testing, compared to records that do not report previous testing, had decreased odds of reporting personal risk (AOR 0.53, 95\% CI: 0.45-0.64). Of the 45 positive test results, $19(42.2 \%)$ were among prenatal care sites but prenatal care sites had the lowest percentage of positive results $(0.1 \%)$ among all testing sites (Table 3).

\section{Discussion}

HIV testing records among Latinas made up the largest proportion of HIV testing events $(41 \%)$, which is greater than their respective adult female population in Florida 
(21.9\%) (Florida Department of Health, n.d.). More than three-quarters of these testing events among Latinas were foreign-born. Both personal and partner risk were frequently reported in the testing records of NHW women. But, previous STD diagnosis, a risk identified in more than one-third of mothers with perinatally exposed infants, was most commonly reported among NHB women (FDOH, 2014; Trepka at al., 2017). Compared to women in other racial/ethnic groups, Latinas in Florida reported the lowest percentage of women aged 18-44 with healthcare insurance coverage while NHW women had a much higher percentage (60.0\% Latinas vs. 80.3\% NHW) (Robbins et. al, 2014). This data could imply that pregnant Latinas, especially foreign-born, may be receiving testing at publicly funded HIV testing sites as part of routine prenatal care, and pregnant NHW and NHB women may be seeking testing based on other motivators such as partner or personal risk factors.

The odds of reporting both personal and partner risk were greater among all site types compared to prenatal care sites. The less frequent report of partner risk may suggest that some women were unaware of their partners' risk behaviors which could have resulted in underreporting partner risk. Perceived low risk and previous HIV testing before pregnancy have been identified as the main reasons for refusing an HIV test (Coleman et al., 2009; Lawrence, Liu \& Towner, 2009). Adherence to the CDC guidelines for universal HIV testing among pregnant women would encourage HIV testing regardless of risk perception and allow for more timely documentation of HIV status among pregnant women and more effective linkage to HIV care (Tan et al. 2011). Medical care providers can serve as conduits to the promotion of these guidelines by 
increasing women's willingness to be testing and reducing stigma associated with HIV testing (Rothpletz-Puglia, 2012; Coleman et al., 2009; King \& Pate, 2014).

HIV testing records from prison/jail testing site type had the greatest odds of reporting previous HIV testing. This finding may suggest fluctuations, by site type, in adherence to CDC's HIV testing recommendations which can affect the potential to identify HIV positive pregnant women (CDC, 2006). Prenatal care sites had more HIV testing events among Latinas, drug treatment sites among NHW, and other healthcare sites among NHB. Results from examining site type suggest that pregnant women were motivated to seek and receive HIV testing based on various reasons concerning HIV risk perception and/or comfort with testing location or provider (King \& Pate, 2014; Rothpletz-Puglia et al., 2012; Coleman et al, 2009). The state of Florida is noted for implementing a comprehensive perinatal HIV prevention program, since 1994, that targets health care providers, HIV-positive pregnant women, and high-risk women. However, even with the most recent Pregnancy Risk Assessment Monitoring System indicating that Florida is achieving one of the highest HIV testing rates among pregnant women in the US, 12.1\% of pregnant women in Florida were not tested in 2013 (FDOH, 2014, FDOH, 2016).

Behaviors that place pregnant women at risk for HIV are similar to those for STDs. In addition to HIV testing, pregnant women should also receive screenings for chlamydia, gonorrhea, hepatitis B, and syphilis at their initial prenatal care visit and at 28-32 weeks of gestation, especially since STD cases have reached the highest numbers ever (Florida Senate Committee on Health Policy, 2007; CDC, 2016). Results also 
revealed that records from those who report personal risk were less likely to report previous HIV testing, meaning they were more likely to be first time testers. This data highlights the importance of adherence to universal testing standards for pregnant women to potentially identify new HIV cases and prevent transmission (CDC, 2006; FDOH, 2013).

The strength of this study is that it provides estimates of HIV risk and testing behaviors among pregnant women publicly testing for HIV and describes HIV testing behaviors and demographics by site type. Several limitations should be noted concerning this study. First, the dataset only included information about HIV testing conducted at publicly funded HIV testing sites. There may be differences in the pregnant women receiving testing services in private versus public HIV testing locations because public HIV testing requires no medical insurance and may explain the large percentage of foreign-born pregnant Latinas accessing services. Therefore, results may not be generalizable to the private medical setting. Second, only self-reported previous HIV testing risk behaviors were documented in the testing records which could explain an underreporting of undesirable behaviors such as HIV risk behaviors and an increase in reporting favorable behaviors such as HIV testing due to social desirability bias (Sionean et al., 2014). Third, due to recommendations to test pregnant women during both the first and third trimester, it is likely that women may be represented multiple times in this dataset. De-duplication of these testing events was not possible due to the de-identified data set available for analysis. The data utilized in this dataset also does not provide a time of gestation to further examine adherence to perinatal HIV testing recommendations. Of the 45 HIV-positive pregnant women identified in this dataset, most reported being 
previously tested for HIV; however, estimates for HIV incidence could not be determined utilizing this dataset because positivity included both previously and newly identified HIV positive individuals (Florida Department of Health, 2013b).

\section{Conclusions}

The results from the study provide evidence that pregnant women continue to have various risk factors that place them and their un-born children at significant risk of acquiring HIV. Identification of HIV infections, especially acute HIV infections, through routine HIV testing during both first and third trimesters will remain a necessary component for the elimination of mother to child transmission as long as there are cases of HIV among women of childbearing age (Trepka et al., 2017; Nesheim et al., 2012; CDC, 2006; Burr et al., 2007; Moyer, 2013). Even with the effectiveness of state and national policy on the increased implementation of perinatal HIV prevention interventions, the results of this study add to the existing literature about patterns of testing among pregnant women specific to the state of Florida (Sarnquist et al., 2007). This new information can be used to enhance existing strategies aimed at improving the prevention of mother to child transmission through the promotion of routine HIV testing and improving prenatal health care (Nesheim et al., 2012, Johnson et al., 2006).

Florida remains disproportionately affected by HIV, with the second highest rate of newly diagnosed HIV infections among adults (age 13+) through the end of 2015 and third highest rate of adults living with HIV through the end of 2014 in the United States (CDC, 2016a). Examining HIV testing site types may reveal motives for HIV testing among pregnant women as variations in reported risk were noted. Variations in reported 
risk by race/ethnicity were also identified. Prevention strategies targeted to pregnant women should be culturally competent and may need to differ based on race/ethnicity. When targeting providers in Florida, understanding site type differences and trends in testing behaviors among pregnant women by site type can be utilized to effectively develop and communicate HIV High Impact Prevention strategies (CDC, 2011). The regular evaluation of testing and counseling data could prove to be very valuable in the evaluation of HIV testing and prenatal care services provided to pregnant women in the State of Florida and assist in enhancing current strategies to eliminate mother to child transmission of HIV (Nesheim et al., 2012, CDC, 2006, Burr et al., 2007, Moyer, 2013).

\section{References}

Burr, C., Lampe, M., Corle, S., Margolin, F., Abresh, C., \& Clark, J. (2007). National organizations "collaborative to eliminate perinatal HIV in the US. An end to perinatal HIV: success in the US requires ongoing and innovative efforts that should expand globally. Journal of Public Health Policy, 28(2), 249-250.

CDC. (2001). Revised recommendations for HIV screening of pregnant women. Morbidity and Mortality Weekly Report, 50(RR19), 59-86. Retrieved from https://www.cdc.gov/mmwr/preview/mmwrhtml/rr5019a2.htm.

CDC. (2006). Revised recommendations for HIV testing of adults, adolescents, and pregnant women in health-care settings. Morbidity and Mortality Weekly Report, 55(RR14), 1-17. Retrieved from http://www.cdc.gov/mmwr/pdf/rr/rr5514.pdf.

CDC. (2011). High-impact prevention: CDC's approach to reducing HIV infections in the United States. Retrieved from http://www.cdc.gov/hiv/pdf/policies_NHPC_Booklet.pdf.

CDC. (2015). CDC-funded HIV testing; United States, Puerto Rico and the U.S. Virgin Islands, 2014. Retrieved from https://www.cdc.gov/hiv/pdf/library/reports/cdc-hivfunded-testing-us-puerto-rico-2014.pdf.

CDC. (2016a). HIV Surveillance Report, 2015, 27. Retrieved from http://www.cdc.gov/hiv/library/reports/hiv-surveillance.html. 
CDC. (2016b). HIV Among Pregnant Women, Infants, and Children. Retrieved from https://www.cdc.gov/hiv/group/gender/pregnantwomen/index.html.

Coleman, V., Morgan, M., Carlson, R., Hawks, D., \& Schulkin, J. (2009). Patient perceptions of obstetrician-gynecologists' practices related to HIV testing. Journal of Maternal Child Health, 13(3), 355-363.

Florida Department of Health. (n.d.). Florida Charts. Retrieved from http://www.floridacharts.com/charts/SpecReport.aspx RepID=7200\&tn=25.

Florida Department of Health. (2013a). Florida's omnibus AIDS act: a brief legal guide for health care professionals. Retrieved from http://www.floridahealth.gov/diseases-andconditions/aids/administration/_documents/Omnibus-booklet-update-2013.pdf.

Florida Department of Health. (2013b). HIV Counseling and Testing Update, 2012. Retrieved from http://www.floridahealth.gov/diseases-andconditions/aids/prevention/_documents/Counseling_testing/2012-counseling/2012ANNUAL-Update.pdf.

Florida Department of Health. (2014). Epidemiology of HIV among women in Florida reported through 2014. Retrieved from http://www.floridahealth.gov/diseases-and conditions/aids/surveillance/epi-slide-sets.html.

Florida Department of Health. (2015). Epidemiologic profile on pediatric HIV/AIDS surveillance in Florida, 2014. Retrieved from http://www.floridahealth.gov/diseases-and-conditions/aids/surveillance/epiprofiles/pediatric-epiprofilereport-2014.pdf.

Florida Department of Health. (2016). Florida pregnancy risk assessment monitoring system (PRAMS) 2013 surveillance data book. Retrieved from http://www.floridahealth.gov/statistics-and-data/survey-data/pregnancy-risk-assessmentmonitoring-system/_documents/reports/prams2013.pdf.

Florida Senate Committee on Health Policy. (2007). Review of the Florida statutes relating to HIV testing. Retrieved from http://archive.flsenate.gov/data/publications/2008/senate/reports/interim_reports/pdf/2008 -134hp.pdf

Johnson, K., Posner, S., Biermann, J., Cordero, J., Atrash, H., Parker, C., Boulet, S., \& Curtis, M. (2006). Recommendations to improve preconception health and healthcare United States. A report of the CDC/ATSDR preconception care work group and the select panel on preconception care. Morbidity and Mortality Weekly Report, 55(RR06), 1-23. Retrieved from https://www.cdc.gov/mmwr/preview/mmwrhtml/rr5506a1.htm. 
Lawrence, J., Liu, I., \& Towner, W. (2009). Trends and correlates of HIV testing during pregnancy in racially/ethnically diverse insured population, 1997-2006. Journal of Maternal Child Health, 13, 633-640.

Lee King, P., \& Pate, D. (2014). Perinatal HIV testing among African American, Caucasian, Hmong and Latina women: exploring the role of health-care services, information sources and perceptions of HIV/AIDS. Health Education Research, 29(1), 109-121.

McKenna, M., \& Hi, X. (2007). Recent trends in the incidence and morbidity that are associated with perinatal human immunodeficiency virus infection in the United States. American Journal of Obstetrics and Gynecology, 197(3), S10-S16.

Moyer, V. (2013). Screening for HIV: U.S. preventive services task force recommendation statement. Annals of Internal Medicine, 159(1), 51-60. Retrieved from http://annals.org/aim/article/1700660/screening-hiv-u-s-preventive-services-task-forcerecommendation-statement.

Nesheim, S., Taylor, A., Lampe, M., Kilmarx, P., Harris, L., Whitmore, S., Griffith, J., Thomas-Proctor, M., Fenton, K., \& Mermin, J. (2012). A framework for elimination of perinatal transmission of HIV in the United States. Pediatrics, 130(4), 738-744. Retrieved from /content/130/4/738.full.html.

Robbins, C., Zapata, L., Farr, S., Kroelinger, C., Morrow, B., Ahluwalia, I., D’Angelo, D., Barradas, D., Cox, S., Goodman, D., Williams, L., Grigorescu, V., \& Barfield, W. (2014). Core state preconception indicators - pregnancy risk assessment monitoring system and behavioral risk factor surveillance system, 2009. Morbidity and Mortality Weekly Report, 63(ss03), 1-62.

Rothpletz-Puglia, P., Storm, D., Burr, C., \& Samuels, D. (2012). Routine prenatal HIV testing: women's concerns and their strategies for addressing concerns. Journal of Maternal Child Health, 16(2), 464-469.

Sansom, S., Harris, N., Sadek, R., Lampe, M., Ruffo, N., \& Fowler, M. (2007). Toward elimination of perinatal human immunodeficiency virus transmission in the United States: effectiveness of funded prevention programs, 1999-2001. American Journal of Obstetrics and Gynecology, 197(3), S90-S95.

Sarnquist, C., Cunningham, S., Sullivan, B., \& Maldonado, Y. (2007). The effectiveness of state and national policy on the implementation of perinatal HIV prevention interventions. American Journal of Public Health, 97(6), 1041-1046

Sionean, C., Le, B.C., Hageman, K., Oster, A.M., Wejnert, C., Hess, K.L., \& Paz-Bailey, G. (2014). HIV risk, prevention, and testing behaviors among heterosexuals at increased risk for HIV infection--National HIV Behavioral Surveillance System, 21 U.S. cities, 
2010. Morbidity and Mortality Weekly Report Surveillance Summary, 63(14), 1-39. Retrieved from http://www.ncbi.nlm.nih.gov/pubmed/25522191.

Tan, K., Lampe, M., Danner, S., Kissinger, P., Webber, M., Cohen, M., O’Sullivan, M., Nesheim, S., \& Jamieson, D. (2011). Factors associated with declining a rapid human immunodeficiency virus test in labor and delivery. Journal of Maternal Child Health, 15(1), 115-121.

Taveras, J., Trepka, M., Khan, H., Madhivanan, P., Gollub, E., \& Devieux, J. (2016). HIV risk behaviors among Latina women tested for HIV in Florida by country of birth, 2012. Journal of Immigrant and Minority Health, 18(5), 1104-1114. Retrieved from http://link.springer.com/article/10.1007/s10903-015-0260-7?no-access=true.

Trepka, M., Mukherjee, S., Beck-Sagué, C., Maddox, L., Fennie, K., Sheehan, D., Prabhakar, M., Thompson, D., \& Lieb, S. (2017). Missed opportunities for prevention perinatal transmission of human immunodeficiency virus, Florida, 2007-2014. Southern Medical Journal, 110(2), 1-13. 
Tables and figures 
Table 1. HIV risk behaviors, previous HIV testing and demographics by race/ethnicity for women pregnant at the time of testing

\begin{tabular}{|c|c|c|c|c|c|c|c|c|}
\hline Race/ethnicity & Total & $\begin{array}{l}\text { Latina } \\
\mathrm{n}(\%)\end{array}$ & $\begin{array}{l}\text { NHW } \\
\text { n (\%) }\end{array}$ & $\begin{array}{l}\text { NHB } \\
\text { n (\%) }\end{array}$ & $\begin{array}{l}\text { Other } \\
\text { n (\%) }\end{array}$ & $\begin{array}{l}\text { Missing } \\
\text { n (\%) }\end{array}$ & $\begin{array}{l}\text { Latina } \\
\text { vs. NHW } \\
p \text {-value }\end{array}$ & $\begin{array}{l}\text { Latina vs. } \\
\text { NHB } \\
p \text {-value }\end{array}$ \\
\hline Total & 24,836 & $\begin{array}{l}\mathrm{n}=10,199 \\
(41.1)\end{array}$ & $\begin{array}{l}\mathrm{n}=6,631 \\
(26.7)\end{array}$ & $\begin{array}{l}(\mathrm{n}=6,796) \\
(27.4)\end{array}$ & $\begin{array}{l}(\mathrm{n}=528) \\
(2.1)\end{array}$ & $\begin{array}{l}(\mathrm{n}=682) \\
(2.7)\end{array}$ & & \\
\hline Mean age (standard deviation) & $\begin{array}{l}26.5 \\
(6.3)\end{array}$ & $\begin{array}{l}27.2 \\
(6.2)\end{array}$ & $\begin{array}{l}25.6 \\
(6.0)\end{array}$ & $\begin{array}{l}26.2 \\
(6.6)\end{array}$ & $\begin{array}{l}28.9 \\
(6.1)\end{array}$ & $\begin{array}{l}26.8 \\
(6.7)\end{array}$ & $<0.0001$ & $<0.0001$ \\
\hline Age group (years) & & & & & & & $<0.0001$ & $<0.0001$ \\
\hline 13-19 & $\begin{array}{l}3,028 \\
(12.2)\end{array}$ & $\begin{array}{l}1,078 \\
(10.6)\end{array}$ & $\begin{array}{l}896 \\
(13.5)\end{array}$ & $\begin{array}{l}972 \\
(14.3)\end{array}$ & $\begin{array}{l}10 \\
(1.9)\end{array}$ & $\begin{array}{l}72 \\
(10.6)\end{array}$ & & \\
\hline 20-29 & $\begin{array}{l}14,369 \\
(57.9)\end{array}$ & $\begin{array}{l}5,605 \\
(55.0)\end{array}$ & $\begin{array}{l}4,202 \\
(63.4)\end{array}$ & $\begin{array}{l}3,870 \\
(57.0)\end{array}$ & $\begin{array}{l}303 \\
(57.4)\end{array}$ & $\begin{array}{l}389 \\
(57.0)\end{array}$ & & \\
\hline 30-39 & $\begin{array}{l}6,749 \\
(27.2)\end{array}$ & $\begin{array}{l}3,245 \\
(31.8)\end{array}$ & $\begin{array}{l}1,377 \\
(20.8)\end{array}$ & $\begin{array}{l}1,736 \\
(25.5)\end{array}$ & $\begin{array}{l}190 \\
(36.0)\end{array}$ & $\begin{array}{l}201 \\
(29.5)\end{array}$ & & \\
\hline $40-49$ & $\begin{array}{l}646 \\
(2.6)\end{array}$ & $\begin{array}{l}261 \\
(2.6)\end{array}$ & $\begin{array}{l}143 \\
(2.2)\end{array}$ & $\begin{array}{l}201 \\
(3.0)\end{array}$ & $\begin{array}{l}23 \\
(4.4)\end{array}$ & $\begin{array}{l}18 \\
(2.6)\end{array}$ & & \\
\hline 50 and over & $\begin{array}{l}44 \\
(0.2)\end{array}$ & $\begin{array}{l}10 \\
(0.1)\end{array}$ & $\begin{array}{l}13 \\
(0.2)\end{array}$ & $\begin{array}{l}17 \\
(0.3)\end{array}$ & $\begin{array}{l}2 \\
(0.4)\end{array}$ & $\begin{array}{l}2 \\
(0.3)\end{array}$ & & \\
\hline Nativity & & & & & & & $<0.0001$ & $<0.0001$ \\
\hline US-born & $\begin{array}{l}3,544 \\
(14.3)\end{array}$ & $\begin{array}{l}837 \\
(8.2)\end{array}$ & $\begin{array}{l}1,037 \\
(15.6)\end{array}$ & $\begin{array}{l}1,584 \\
(23.3)\end{array}$ & $\begin{array}{l}21 \\
(4.0)\end{array}$ & $\begin{array}{l}65 \\
(9.5)\end{array}$ & & \\
\hline Foreign-born & $\begin{array}{l}11,384 \\
(45.8)\end{array}$ & $\begin{array}{l}7,669 \\
(75.2)\end{array}$ & $\begin{array}{l}664 \\
(10.0)\end{array}$ & $\begin{array}{l}2,313 \\
(34.0)\end{array}$ & $\begin{array}{l}407 \\
(77.1)\end{array}$ & $\begin{array}{l}331 \\
(48.5)\end{array}$ & & \\
\hline Missing & $\begin{array}{l}9,908 \\
(39.9)\end{array}$ & $\begin{array}{l}1,693 \\
(16.6)\end{array}$ & $\begin{array}{l}4,930 \\
(74.4)\end{array}$ & $\begin{array}{l}2,899 \\
(42.7)\end{array}$ & $\begin{array}{l}100 \\
(18.9)\end{array}$ & $\begin{array}{l}286 \\
(41.9)\end{array}$ & & \\
\hline Any personal risk & $\begin{array}{l}1,619 \\
(6.5)\end{array}$ & $\begin{array}{l}308 \\
(3.0)\end{array}$ & $\begin{array}{l}638 \\
(9.6)\end{array}$ & $\begin{array}{l}619 \\
(9.1)\end{array}$ & $\begin{array}{l}17 \\
(3.2)\end{array}$ & $\begin{array}{l}37 \\
(5.4)\end{array}$ & $<0.0001$ & $<0.0001$ \\
\hline
\end{tabular}




\begin{tabular}{|c|c|c|c|c|c|c|c|c|}
\hline $\begin{array}{l}\text { Sex for drugs/money/other items } \\
\text { (anal, vaginal or oral) }\end{array}$ & $\begin{array}{l}269 \\
(1.1)\end{array}$ & $\begin{array}{l}41 \\
(0.4)\end{array}$ & $\begin{array}{l}151 \\
(2.3)\end{array}$ & $\begin{array}{l}69 \\
(1.0)\end{array}$ & $\begin{array}{l}2 \\
(0.4)\end{array}$ & $\begin{array}{l}6 \\
(0.9)\end{array}$ & $<0.0001$ & $<0.0001$ \\
\hline STD diagnosis & $\begin{array}{l}1,177 \\
(4.7)\end{array}$ & $\begin{array}{l}259 \\
(2.5)\end{array}$ & $\begin{array}{l}322 \\
(4.9)\end{array}$ & $\begin{array}{l}552 \\
(8.1)\end{array}$ & $\begin{array}{l}14 \\
(2.7)\end{array}$ & $\begin{array}{l}30 \\
(4.4)\end{array}$ & $<0.0001$ & $<0.0001$ \\
\hline Injection drug use & $\begin{array}{l}329 \\
(1.3)\end{array}$ & $\begin{array}{l}22 \\
(0.2)\end{array}$ & $\begin{array}{l}284 \\
(4.3)\end{array}$ & $\begin{array}{l}16 \\
(0.2)\end{array}$ & $\begin{array}{l}1 \\
(0.2)\end{array}$ & $\begin{array}{l}6 \\
(0.9)\end{array}$ & $<0.0001$ & 0.7897 \\
\hline Any partner risk & $\begin{array}{l}428 \\
(1.7)\end{array}$ & $\begin{array}{l}51 \\
(0.5)\end{array}$ & $\begin{array}{l}318 \\
(4.8)\end{array}$ & $\begin{array}{l}48 \\
(0.7)\end{array}$ & $\begin{array}{l}2 \\
(0.4)\end{array}$ & $\begin{array}{l}9 \\
(1.3)\end{array}$ & $<0.0001$ & 0.0835 \\
\hline $\begin{array}{l}\text { Sex (vaginal or anal) with HIV- } \\
\text { positive person }\end{array}$ & $\begin{array}{l}66 \\
(0.3)\end{array}$ & $\begin{array}{l}13 \\
(0.1)\end{array}$ & $\begin{array}{l}25 \\
(0.4)\end{array}$ & $\begin{array}{l}25 \\
(0.4)\end{array}$ & $\begin{array}{l}1 \\
(0.2)\end{array}$ & $\begin{array}{l}2 \\
(0.3)\end{array}$ & 0.0009 & 0.0012 \\
\hline $\begin{array}{l}\text { Sex (vaginal or anal) with an } \\
\text { IDU }\end{array}$ & $\begin{array}{l}319 \\
(1.3)\end{array}$ & $\begin{array}{l}29 \\
(0.3)\end{array}$ & $\begin{array}{l}273 \\
(4.1)\end{array}$ & $\begin{array}{l}9 \\
(0.1)\end{array}$ & $\begin{array}{l}2 \\
(0.4)\end{array}$ & $\begin{array}{l}6 \\
(0.9)\end{array}$ & $<0.0001$ & 0.0400 \\
\hline $\begin{array}{l}\text { Sex (vaginal or anal) with a } \\
\text { MSM }\end{array}$ & $\begin{array}{l}68 \\
(0.3)\end{array}$ & $\begin{array}{l}14 \\
(0.1)\end{array}$ & $\begin{array}{l}36 \\
(0.5)\end{array}$ & $\begin{array}{l}16 \\
(0.2)\end{array}$ & $\begin{array}{l}0 \\
(0.0)\end{array}$ & $\begin{array}{l}2 \\
(0.3)\end{array}$ & $<0.0001$ & 0.1353 \\
\hline Any personal or partner risk & $\begin{array}{l}1,790 \\
(7.2)\end{array}$ & $\begin{array}{l}334 \\
(3.3)\end{array}$ & $\begin{array}{l}747 \\
(11.3)\end{array}$ & $\begin{array}{l}650 \\
(9.6)\end{array}$ & $\begin{array}{l}18 \\
(3.4)\end{array}$ & $\begin{array}{l}41 \\
(6.0)\end{array}$ & & \\
\hline Previous HIV testing & & & & & & & $<0.0001$ & $<0.0001$ \\
\hline Yes & $\begin{array}{l}20,281 \\
(81.7)\end{array}$ & $\begin{array}{l}8,248 \\
(80.9)\end{array}$ & $\begin{array}{l}5,269 \\
(79.5)\end{array}$ & $\begin{array}{l}5,861 \\
(86.2)\end{array}$ & $\begin{array}{l}373 \\
(70.6)\end{array}$ & $\begin{array}{l}530 \\
(77.7)\end{array}$ & & \\
\hline No & $\begin{array}{l}3,284 \\
(13.2)\end{array}$ & $\begin{array}{l}1,461 \\
(14.3)\end{array}$ & $\begin{array}{l}921 \\
(13.9)\end{array}$ & $\begin{array}{l}689 \\
(10.4)\end{array}$ & $\begin{array}{l}113 \\
(21.4)\end{array}$ & $\begin{array}{l}100 \\
(14.7)\end{array}$ & & \\
\hline Don't Know/refused & $\begin{array}{l}1,271 \\
(5.1)\end{array}$ & $\begin{array}{l}490 \\
(4.8)\end{array}$ & $\begin{array}{l}441 \\
(6.7)\end{array}$ & $\begin{array}{l}246 \\
(3.6)\end{array}$ & $\begin{array}{l}42 \\
(8.0)\end{array}$ & $\begin{array}{l}52 \\
(7.6)\end{array}$ & & \\
\hline Positivity & & & & & & & 0.1532 & $<0.0001$ \\
\hline Yes & $\begin{array}{l}45 \\
(0.2)\end{array}$ & $\begin{array}{l}7 \\
(0.07)\end{array}$ & $\begin{array}{l}9 \\
(0.1)\end{array}$ & $\begin{array}{l}28 \\
(0.4)\end{array}$ & $\begin{array}{l}0 \\
(0.0)\end{array}$ & $\begin{array}{l}1 \\
(0.2)\end{array}$ & & \\
\hline No & $\begin{array}{l}24,783 \\
(99.8)\end{array}$ & $\begin{array}{l}10,186 \\
(99.9)\end{array}$ & $\begin{array}{l}6,621 \\
(99.9)\end{array}$ & $\begin{array}{l}6,767 \\
(99.6)\end{array}$ & $\begin{array}{l}528 \\
(100.0)\end{array}$ & $\begin{array}{l}681 \\
(99.9)\end{array}$ & & \\
\hline
\end{tabular}


NHB = Non-Hispanic Black, NHW = Non-Hispanic White, STD = sexually transmitted disease, HIV = human immunodeficiency virus, IDU = injection drug user, MSM = man that has sex with men

${ }^{\text {a }}$ Chi-squared statistics were used to compare the variables. The statistical significance level alpha was set to 0.05

${ }^{\mathrm{b}}$ Indeterminate/missing HIV tests without a confirmatory result 
Table 2. Adjusted odds ratio estimates for previous HIV testing among women tested for HIV in Florida 2012, by reported pregnancy at time of testing

\begin{tabular}{|c|c|c|c|}
\hline & $\begin{array}{l}\text { Personal Risk OR } \\
(95 \% \text { CI })\end{array}$ & $\begin{array}{l}\text { Partner Risk OR } \\
(95 \% \text { CI })\end{array}$ & $\begin{array}{l}\text { Previous Testing OR } \\
(95 \% \text { CI })\end{array}$ \\
\hline \multicolumn{4}{|c|}{ Model 1 Independent variable race/ethnicity } \\
\hline Non-Hispanic White & Referent & Referent & Referent \\
\hline Latina & $0.47(0.40,0.55)$ & $0.20(0.14,0.28)$ & $1.09(0.99,1.19)$ \\
\hline Non-Hispanic Black & $1.17(1.01,1.35)$ & $0.14(0.10,0.21)$ & $1.69(1.52,1.88)$ \\
\hline Other & $0.54(0.33,0.90)$ & $0.14(0.03,0.59)$ & $0.50(0.41,0.62)$ \\
\hline Missing & $0.76(0.53,1.10)$ & $0.49(0.24,1.03)$ & $0.91(0.74,1.12)$ \\
\hline \multicolumn{4}{|c|}{ Model $2^{\text {b }}$ Independent variable nativity } \\
\hline US-born & Referent & Referent & Referent \\
\hline Foreign-born & $0.27(0.22,0.35)$ & $0.18(0.10,0.34)$ & $0.65(0.55,0.76)$ \\
\hline Missing & $0.75(0.60,0.93)$ & $0.79(0.48,1.30)$ & $0.76(0.64,0.90)$ \\
\hline \multicolumn{4}{|c|}{ Model $3^{b}$ Independent variable site type } \\
\hline Prenatal care & Referent & Referent & Referent \\
\hline STD clinic & $5.25(3.58,7.68)$ & $5.65(2.56,12.46)$ & $1.09(0.77,1.55)$ \\
\hline Drug treatment & $9.49(5.29,17.03)$ & $34.74(13.79,87.49)$ & $1.04(0.58,1.88)$ \\
\hline Prison/jail & $7.78(4.60,13.16)$ & $34.53(14.73,80.97)$ & $1.86(1.03,3.39)$ \\
\hline
\end{tabular}




\begin{tabular}{|c|c|c|c|}
\hline Other non-healthcare & $2.50(1.80,3.49)$ & $16.17(8.87,29.45)$ & $0.95(0.72,1.26)$ \\
\hline Other healthcare & $2.00(1.28,3.14)$ & $12.66(5.94,27.00)$ & $0.73(0.51,1.04)$ \\
\hline \multicolumn{4}{|c|}{ Model 4 $4^{b}$ Independent variable previous HIV testing } \\
\hline No previous HIV testing & Referent & Referent & $\mathrm{n} / \mathrm{a}$ \\
\hline Previous HIV testing & $0.53(0.45,0.64)$ & $1.38(0.97,1.96)$ & $\mathrm{n} / \mathrm{a}$ \\
\hline
\end{tabular}


Table 3. HIV risk behaviors, previous testing and positivity of Latinas reporting currently pregnant at time of testing by testing site type

\begin{tabular}{|c|c|c|c|c|c|c|c|}
\hline Site Type & $\begin{array}{l}\text { STD Clinic } \\
\mathrm{n}(\%)\end{array}$ & $\begin{array}{l}\text { Drug } \\
\text { Treatment } \\
\text { n }(\%)\end{array}$ & $\begin{array}{l}\text { Prison/Jail } \\
\text { n }(\%)\end{array}$ & $\begin{array}{l}\text { Prenatal } \\
\text { Care } \\
\text { n }(\%)\end{array}$ & $\begin{array}{l}\text { Other non- } \\
\text { healthcare } \\
\text { n }(\%)\end{array}$ & $\begin{array}{l}\text { Other } \\
\text { healthcare } \\
\text { n }(\%)\end{array}$ & $p$-value ${ }^{\mathrm{a}}$ \\
\hline Total & $\begin{array}{c}\mathrm{n}=1,245 \\
(5.0)\end{array}$ & $\begin{array}{l}\mathrm{n}=433 \\
(1.7)\end{array}$ & $\begin{array}{l}\mathrm{n}=271 \\
(1.1)\end{array}$ & $\begin{array}{l}\mathrm{n}=19,115 \\
(76.9)\end{array}$ & $\begin{array}{l}\mathrm{n}=3,007 \\
(12.1)\end{array}$ & $\begin{array}{l}\mathrm{n}=765 \\
(3.1)\end{array}$ & \\
\hline Mean age (standard deviation) & $24.6(6.1)$ & $26.9(5.1)$ & $26.4(6.2)$ & $26.6(6.1)$ & $26.9(6.8)$ & $26.6(8.3)$ & \\
\hline Age group (years) & & & & & & & $<0.0001$ \\
\hline 13-19 & $272(21.8)$ & $13(3.0)$ & $23(8.5)$ & $2,241(11.7)$ & $369(12.3)$ & $110(14.4)$ & \\
\hline $20-29$ & $729(58.6)$ & $306(70.7)$ & $181(66.8)$ & $11,061(57.9)$ & $1,639(54.5)$ & $453(59.2)$ & \\
\hline $30-39$ & $216(17.4)$ & $109(25.2)$ & $58(21.4)$ & $5,336(27.9)$ & $874(29.1)$ & $156(20.4)$ & \\
\hline $40-49$ & $27(2.2)$ & $4(0.9)$ & $6(2.2)$ & $470(2.5)$ & $113(3.8)$ & $26(3.4)$ & \\
\hline 50 and over & $1(0.1)$ & $1(0.2)$ & $3(1.1)$ & $7(0.0)$ & $12(0.4)$ & $20(2.6)$ & \\
\hline Race/ethnicity & & & & & & & $<0.0001$ \\
\hline Latina & $223(18.3)$ & $18(4.2)$ & $49(18.2)$ & $8,593(45.6)$ & $1,111(37.5)$ & $205(27.2)$ & \\
\hline NHW & $521(42.7)$ & $353(82.3)$ & $115(42.8)$ & $5,172(27.4)$ & $352(11.9)$ & $118(15.6)$ & \\
\hline NHB & $451(37.0)$ & $53(12.4)$ & $104(38.7)$ & $4,362(23.2)$ & $1,424(48.1)$ & $402(53.3)$ & \\
\hline Other & $16(1.3)$ & $1(0.2)$ & $1(0.4)$ & $447(2.4)$ & $45(1.5)$ & $18(2.4)$ & \\
\hline Missing & $9(0.7)$ & $4(0.9)$ & $0(0.0)$ & $272(1.4)$ & $31(1.1)$ & $12(1.6)$ & \\
\hline Nativity & & & & & & & $<0.0001$ \\
\hline US-born & $607(48.8)$ & $79(18.2)$ & $232(85.6)$ & $594(3.1)$ & $1,195(39.7)$ & $454(59.4)$ & \\
\hline Foreign-born & $218(17.5)$ & $5(1.2)$ & $8(3.0)$ & 9,871 (51.6) & $1,437(47.8)$ & $228(29.8)$ & \\
\hline
\end{tabular}




\begin{tabular}{llllllll}
\hline missing & $420(33.7)$ & $349(80.6)$ & $31(11.4)$ & $8,650(45.3)$ & $375(12.5)$ & $83(10.9)$ & \\
Any personal risk & $242(19.4)$ & $180(41.6)$ & $78(28.8)$ & $816(4.3)$ & $231(7.7)$ & $72(9.4)$ & $<0.0001$ \\
$\begin{array}{l}\text { Sex for drugs/money/other items } \\
\text { (anal, vaginal or oral) }\end{array}$ & $21(1.7)$ & $71(16.4)$ & $35(12.9)$ & $64(0.3)$ & $65(2.2)$ & $13(1.7)$ & $<0.0001$ \\
STD diagnosis & & & & & & & \\
Injection drug use & $214(17.2)$ & $24(5.5)$ & $27(10.0)$ & $700(3.7)$ & $157(5.2)$ & $55(7.2)$ & $<0.0001$ \\
Any partner risk & $19(1.5)$ & $138(31.9)$ & $35(12.9)$ & $85(0.4)$ & $40(1.3)$ & $12(1.6)$ & $<0.0001$ \\
Sex (vaginal or anal) with HIV- & $7(0.6)$ & $1(0.2)$ & $3(1.1)$ & $8(0.0)$ & $30(1.0)$ & $17(2.2)$ & $<0.0001$ \\
positive person & $26(2.1)$ & $141(32.6)$ & $33(12.2)$ & $121(0.6)$ & $82(2.7)$ & $25(3.3)$ & $<0.0001$ \\
Sex (vaginal or anal) with an IDU & $15(1.2)$ & $137(31.6)$ & $29(10.7)$ & $93(0.5)$ & $37(1.2)$ & $8(1.1)$ & $<0.0001$ \\
Sex (vaginal or anal) with a MSM & $6(0.5)$ & $6(1.4)$ & $2(0.7)$ & $29(0.2)$ & $22(0.7)$ & $3(0.4)$ & $<0.0001$ \\
Any personal or partner risk & $252(20.2)$ & $205(47.3)$ & $87(32.1)$ & $879(4.6)$ & $278(9.3)$ & $89(11.6)$ & $<0.0001$ \\
Previous HIV testing & & & & & & $<0.0001$ \\
Yes & $1,014(81.5)$ & $280(64.7)$ & $251(92.6)$ & $15,800(82.7)$ & $2,335(77.7)$ & $601(78.6)$ & \\
No & $163(13.1)$ & $16(3.7)$ & $18(6.6)$ & $2,367(12.4)$ & $577(19.2)$ & $143(18.7)$ & $21(2.8)$ \\
Don't Know/refused & $68(5.5)$ & $137(31.6)$ & $2(0.7)$ & $948(5.0)$ & $95(3.2)$ & &
\end{tabular}

NHB = Non-Hispanic Black, NHW = Non-Hispanic White, STD = sexually transmitted disease, HIV = human immunodeficiency virus, $\mathrm{IDU}=$ injection drug user, MSM = man that has sex with men, US = United States 
${ }^{a}$ Chi-square statistics were used to compare the variables. Fisher's exact test was used for cell frequencies less than 5 . The statistical significance level alpha was set to 0.05 .

${ }^{\mathrm{b}}$ Indeterminate/missing HIV tests without a confirmatory result 


\section{CONCLUSIONS}

To our knowledge, this is the first study that utilized a large state-wide dataset, and that encompasses a diverse sample of Latinas, to identify HIV risk differences among Latinas by country of birth. Findings from this study demonstrate that reported risk behaviors varied by race/ethnicity, US-born versus foreign-born status, and by Latina

country of origin. Based on this information, HIV prevention messages should be tailored for Latinas, taking into account cultural differences and nativity, to increase effectiveness.

This study also indicates that Latinas are underutilizing HIV testing services, and efforts are needed to increase the proportion of Latinas, especially younger Latinas, who should get tested for HIV in Florida. The less frequent self-reporting of partner risk reveals that attention should be given to the topic of partner risk and susceptibility to HIV. Furthermore, results from the study provide evidence that pregnant women continue to have various risk factors that place them and their un-born children at significant risk of acquiring HIV. Identification of HIV infections, especially acute HIV infections, through routine HIV testing during both first and third trimesters will remain a necessary component for the elimination of mother-to-child transmission as long as there are cases of HIV among women of childbearing age.

The regular evaluation of testing and counseling data could prove to be of considerable value in the appraisal of effective HIV prevention, HIV testing, and care services provided to women in the State of Florida and assist in enhancing current strategies to reduce transmission of HIV. It is important to have established monitoring 
and evaluation practices, such as regular examination of counseling and testing data, to appropriately measure prevention effectiveness and subsequently progress toward the goals of the National HIV/AIDS Strategy. Future studies should further examine the concept of partner behaviors as it relates to culture and HIV risk among Latinas. The collection of risk and prevention behavior data should be incorporated as part of all HIV testing, regardless of funding source and routinely analyzed to enhance HIV programing and evaluation. 
VITA

JANELLE TAVERAS

Born, Northampton, Massachusetts

\begin{tabular}{|c|c|}
\hline \multirow[t]{3}{*}{$2001-2005$} & B.S., Biology \\
\hline & Barry University \\
\hline & Miami, Florida \\
\hline \multirow[t]{3}{*}{$2006-2008$} & M.P.H, Public Health Epidemiology concentration \\
\hline & Florida International University \\
\hline & Miami, Florida \\
\hline \multirow[t]{3}{*}{$2008-2010$} & Graduate Assistant \\
\hline & Florida International University \\
\hline & Miami, Florida \\
\hline \multirow[t]{3}{*}{$2008-2011$} & Project Coordinator \\
\hline & Florida Department of Health in Miami-Dade County \\
\hline & Miami, Florida \\
\hline \multirow[t]{3}{*}{$2011-2013$} & Project Evaluator \\
\hline & Florida Department of Health in Miami-Dade County \\
\hline & Miami, Florida \\
\hline \multirow[t]{3}{*}{ 2013_present } & Program Evaluator \\
\hline & Florida Department of Health in Broward County \\
\hline & Fort Lauderdale, Florida \\
\hline \multirow[t]{3}{*}{2011 -present } & Doctoral Candidate \\
\hline & Florida International University \\
\hline & Miami, Florida \\
\hline
\end{tabular}




\section{PUBLICATIONS AND PRESENTATIONS}

Carey, J. W., LaLota, M., Villamizar, K., McElroy, T., Wilson, M. M., Garcia, J., \& Flores, S. A. (2015). Using High-Impact HIV Prevention to Achieve the National HIV/AIDS Strategic Goals in Miami-Dade County, Florida: A Case Study. Journal of Public Health Management \& Practice, 21(6), 584-593.

doi:10.1097/PHH.0000000000000321

Taveras, J., Trepka, M., Khan, H., Madhivanan, P., Gollub, E., \& Devieux, J. (2016). HIV risk behaviors among Latina women tested for HIV in Florida by country of birth, 2012. Journal of Immigrant and Minority Health, 18(5), 1104-1114.

Taveras, J., Trepka, M., Khan, H., Madhivanan, P., Gollub, E., \& Devieux, J. (2017). HIV testing behaviors among Latina women testing for HIV in Florida, 2012. Hispanic Health Care International, 15(1), 27-34.

Wingood, G. M., DiClemente, R. J., Villamizar, K., Er, D. L., DeVarona, M., Taveras, J., \& Jean, R. (2011). Efficacy of a Health Educator-Delivered HIV Prevention Intervention for Latina Women: A Randomized Controlled Trial. American Journal of Public Health, 101(12), 22452252. doi:10.2105/AJPH.2011.300340 